\title{
Science to Support DOE Site Cleanup: The Pacific Northwest National Laboratory Environmental Management Science Program Awards
}

Fiscal Year 2001 Mid-Year Progress Report

June 2001

Prepared for the U.S. Department of Energy under Contract DE-AC06-76RL01830 


\title{
DISCLAIMER
}

This report was prepared as an account of work sponsored by an agency of the United States Government. Neither the United States Government nor any agency thereof, nor Battelle Memorial Institute, nor any of their employees, makes any warranty, express or implied, or assumes any legal liability or responsibility for the accuracy, completeness, or usefulness of any information, apparatus, product, or process disclosed, or represents that its use would not infringe privately owned rights. Reference herein to any specific commercial product, process, or service by trade name, trademark, manufacturer, or otherwise does not necessarily constitute or imply its endorsement, recommendation, or favoring by the United States Government or any agency thereof, or Battelle Memorial Institute. The views and opinions of authors expressed herein do not necessarily state or reflect those of the United States Government or any agency thereof.

\author{
PACIFIC NORTHWEST NATIONAL LABORATORY \\ operated by \\ BATTELLE \\ for the \\ UNITED STATES DEPARTMENT OF ENERGY \\ under Contract DE-AC06-76RL01830
}

Printed in the United States of America

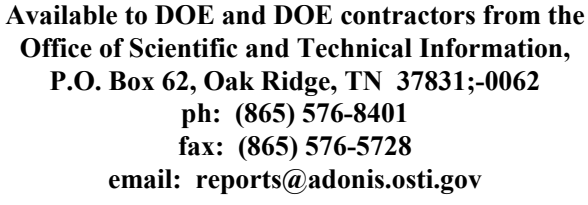

\footnotetext{
Available to the public from the National Technical Information Service, U.S. Department of Commerce, 5285 Port Royal Rd., Springfield, VA 22161 ph: (800)553-6847 fax: (703) 605-6900

email: orders@ntis.fedworld.gov

online ordering: http://www.ntis.gov/ordering.htm
} 
Science to Support DOE Site Cleanup:

The Pacific Northwest National Laboratory

Environmental Management

Science Program Awards

Fiscal Year 2001 Mid-Year Progress Report

June 2001

Prepared for

the U.S. Department of Energy

under Contract DE-AC06-76RL01830

Pacific Northwest National Laboratory

Richland, Washington 99352 


\section{Summary}

Pacific Northwest National Laboratory (PNNL) was awarded ten Environmental Management Science Program (EMSP) research grants in fiscal year 1996, six in fiscal year 1997, nine in fiscal year 1998, seven in fiscal year 1999, and five in fiscal year 2000. ${ }^{\text {(a) }}$ All of the fiscal year 1996 award projects have published final reports. The 1997 and 1998 award projects have been completed or are nearing completion. Final reports for these awards will be published, so their annual updates will not be included in this document. This section summarizes how each of the 1999 and 2000 grants address significant U.S. Department of Energy (DOE) cleanup issues, including those at the Hanford Site. The technical progress made to date in each of these research projects is addressed in more detail in the individual progress reports contained in this document.

The 1999 and 2000 EMSP awards at PNNL are focused primarily in two areas: Tank Waste Remediation, and Soil and Groundwater Cleanup.

\section{Tank Waste Remediation}

One of the main problems facing DOE is the 350,000 cubic meters ( 92 million gallons) of mixed chemical and radioactive waste stored in more than 300 underground storage tanks at the Hanford Site (Washington), Oak Ridge Reservation (Tennessee), Savannah River Site (South Carolina), Idaho National Engineering and Environmental Laboratory (Idaho), and West Valley Site (New York). These tanks contain about 70\% (720 million curies) of the man-made radioactivity existing in the DOE complex in the form of liquids, sludges, saltcake, and calcined solids (at Idaho). Remediation of this tank waste is one of the most technically complex, scientifically challenging, and potentially expensive problems facing DOE.

Hanford has $60 \%$ of the waste volume and $30 \%$ of the radioactivity for all DOE high-level waste tanks. At Hanford, 177 underground storage tanks contain 210,000 cubic meters ( 54 million gallons) of high-level waste. The current baseline approach to remediating this tank waste is to retrieve the waste and then separate the solids from the liquids. Once cesium, strontium, and other radionuclides are removed from the liquid, it will become a relatively low-activity stream that can be immobilized as low-level radioactive and chemical waste. The solid, high-activity stream will be pretreated to reduce its volume (mainly through the removal of nonradioactive inorganic components such as chromium, phosphorous, and aluminum) and then immobilized as high-level radioactive waste.

(a) PNNL researchers are the lead principal investigators in these 37 projects. PNNL also collaborates with researchers at other institutions on 39 other EMSP projects. This document, however, does not include the annual reports for most of those collaborations, which are submitted through the lead institutions. 


\section{Safe Storage}

Even safe storage of the waste in the tanks gives rise to technical issues. Chemical reactions in the tanks, including those caused by radiation and the slow corrosion of the steel tank walls, produce gases such as hydrogen, nitrogen, nitrous oxide, ammonia, and methane. Many of these gases are flammable, toxic, or both. In addition to generating gases, the reactions degrade organic compounds in the waste, change organic fuel and oxidant concentrations, and alter the surface chemistry of insoluble colloids, influencing sedimentation and gas/solid interactions. The EMSP project "Mechanisms and Kinetics of Organic Aging in High-Level Nuclear Wastes" is focused on understanding the radiolytic processes in these mixed-phase systems. The goals are to determine and understand the radiation-induced physical and chemical changes in the wastes and the rates at which they occur.

\section{Characterization}

Characterizing the complex and heterogeneous wastes is difficult and expensive. Yet, an adequate characterization is vital to making decisions about each treatment and storage step. At Hanford, waste delivered to the pretreatment system must be demonstrated to be within certain specifications on composition, solids content, and several other criteria. Cost and final disposition of the high-level waste form will depend on the waste content of the immobilized product.

\section{Retrieval and Waste Transfer}

The wastes are complex and highly alkaline mixtures of many species, with sodium, nitrate, and hydroxide predominant. Some of the most interesting thermodynamics in the waste involve aluminum phases, which can precipitate or dissolve during waste processing depending on the waste's $\mathrm{pH}$ and the concentrations of certain ions. Changes in $\mathrm{pH}$ or waste composition during waste retrieval, transfer, and processing must be done thoughtfully to prevent unwanted precipitation or scale formation. Of all constituents of tank waste, aluminum species have the greatest potential for clogging pipes and transfer lines, fouling highly radioactive components, and shutting down processing operations.

The EMSP project "Non-Invasive Diagnostics to Measure Physical Properties in High Level Wastes" is a renewal of a 1996 award, "On-Line Slurry Viscosity and Concentration Measurement as a Real-Time Waste Stream Characterization Tool," which PNNL co-leads with the University of California, Davis. This project is focused on the development of a technique that can determine rheological properties, solids loading, and mass flow of tank wastes under processing conditions to permit the monitoring and control of slurries during transport.

\section{Pretreatment}

Several EMSP projects are investigating innovative approaches in the area of separation processes. Radionuclides must be removed to prepare the liquid waste stream for immobilization as low-level waste, while nonradioactive species must be extracted from the 
high-activity waste stream to minimize its volume. Both aspects present a series of technical challenges.

Current strategies for reducing the volume of the solid, high-activity waste stream involve developing methods to selectively dissolve and remove nonradioactive elements such as aluminum, phosphorus, and chromium while retaining the radioactive elements in the sludges.

Turning to the low-level waste stream, the removal of cesium appears to be straightforward, with ion-exchange technologies capable of meeting the performance criteria. In conventional ionexchange processes, the cesium-bearing liquid passes through a reactor packed with an organic resin or other ion-exchange material. The cesium binds to the resin but not permanently. Once the resin has reached its cesium capacity, the cesium is flushed from the resin with acid and reused. However, this creates a second liquid waste stream that must be processed further (e.g., by incorporating into borosilicate glass) for long-term storage or disposal.

The EMSP project "New Metal Niobate and Silicotitanate Ion Exchangers: Development and Characterization" is a renewal of our 1997 award, "New Silicotitanate Waste Forms: Development and Characterization." Crystalline silicotitanate (CST) is the most promising commercially available candidate for removal of cesium and strontium from tank wastes; however, it has been identified as a risk to vitrification due to its high level of $\mathrm{TiO}_{2}$. Our 1997 project developed strategies for disposing of crystalline silicotitanate (CST) ion exchangers by in situ heat treatment with minimal or no additives to produce an alternative waste form. The renewal project builds on the results obtained from our previous project and focuses on the current needs in separation of cesium and strontium. This approach could significantly reduce the volume and costs associated with waste disposal, minimize the risk of environmental contamination during processing, eliminate problems associated with radiolytic hydrogen generation during short-term storage, and provide DOE with technical alternatives for waste disposal. Due to this work and other EM-50-funded projects, CSTs are being considered as one of three cesium-removal technologies at the Savannah River Site.

In some tanks, there may be a need to remove the lanthanides and actinides (because or their long half-lives of $10^{2}$ to $10^{6}$ years) and/or strontium, which has been complexed by organic chelating agents present in the waste. Partitioning during the separation process is complicated by the presence of organic chelating agents, which bind up both radionuclides and nonradioactive metals. During pretreatment, the radionuclides must be displaced from the chelating agents by manipulating the hydroxide concentration of other metals. To minimize the high-level waste volume, however, this displacement must be selective. Designing a selective separation process for the highly complex waste without resorting to an ad hoc approach requires a fundamental understanding of what controls the conformation of the chelating agents and their interactions with metals and other ions. "Development of Fundamental Data on Chemical Speciation for Strontium and Americium in High-Level Waste: Predictive Modeling of Phase Partitioning During Tank Processing" is a renewal of a 1996 award of the same title. This project addresses the problem of trivalent actinide (americium/cesium) and strontium speciation and solubility in tank liquids. The resulting data will be used to develop 
thermodynamic models to predict changes in chemical speciation and solubility as a result of changes in tank processing conditions. In this way, existing processes can be optimized and new processes can be developed.

The EMSP project "Computational Design of Metal Ion Sequestering Agents" is a renewal of a 1996 project, "Architectural Design Criteria for $\boldsymbol{f}$-Block Metal Sequestering Agents." This project uses computational and experimental methods to optimize ligand architecture for metal sequestrations, including actinides and lanthanides. By developing an accurate set of criteria for ligand architecture design, ligand structure can be targeted for synthesis, dramatically reducing the time and cost associated with metal-specific ligand development. This provides cleanup projects with more cost-effective and efficient separations agents that can reduce schedules and save money, especially the costs associated with the regeneration of separations materials and/or the disposal of spent separations materials.

\section{Immobilization}

Once the high-activity stream has been reduced in volume, the remaining waste, with its concentrated radionuclides, will be immobilized. The approach DOE has chosen for most of its sites is to vitrify the waste, that is, to incorporate it into glass. With DOE support, large electrically heated melters have been developed for waste processing.

\section{Storage and Disposal}

Once immobilized, the low-activity waste will be disposed on site, while the high-activity waste is to be disposed at the federal geologic repository. However, interactions between alkali ions (such as sodium) and radionuclides in the immobilized waste that could affect their release rate are not well understood. The impact of internal radiation on the long-term performance of these immobilized forms is also unclear. And, given the time frames involved (ca. 10,000 years) the data will not be gathered from simple experimentation. The EMSP project "Radiation Effects in Nuclear Waste Materials" is a renewal of a 1996 award of the same title. This project is focused on developing a fundamental understanding of radiation effects in glass and ceramic waste forms. The understanding and associated data from this project has shown that the baseline formulation for low-level waste (LLW) glass would not meet regulatory leaching requirements for long-term disposal. This data has been used to reformulate the LLW glass to provide a final product that will retain the radionuclides of interest within the regulatory limits. It is also important to note that these studies will benefit the assessment of waste forms proposed for the immobilization and disposal of plutonium residues and scrap and excess weapons plutonium. 


\section{Soil and Groundwater Cleanup}

Contaminant plumes, contaminated soils, and landfills account for some 4,800 waste sites on DOE property in 31 states. Approximately 35 million cubic meters of soil are contaminated with low-level and mixed low-level waste. Another 1.2 million cubic meters of soil are contaminated with transuranic and mixed transuranic waste. Landfills of buried waste are estimated to contain 3 million cubic meters of low-level waste. This includes 105,000 cubic meters of retrievably stored transuranic waste. Several hundred square miles of groundwater are contaminated with a variety of radionuclides and hazardous chemicals in concentrations above drinking water standards and DOE's concentration guidelines. At Hanford alone there are nearly 150 square miles of groundwater contamination. The radioactive and hazardous wastes are dispersed through large volumes of soil and groundwater, making potential treatment by conventional soil excavation and groundwater cleanup technologies ineffective and costly. In addition, some 650,000 metric tons of solid waste are buried at Hanford.

In 1997, part of the DOE call for proposals was designed to help the project fill many of the gaps in knowledge through EMSP. The baseline approach for treating contaminated groundwaters was to pump out the groundwater, treat it ex situ, and return it to the subsurface ("pump and treat"). For contaminated soils, the plan is simple: dig it up and dispose of it in a controlled disposal unit. At Hanford, that unit is the Environmental Restoration Disposal Facility (ERDF).

The ERDF, centrally located on the 200 Area plateau, is receiving contaminated soils and solid waste from the 100 Area. As of last year, two cells were operating with a capacity of approximately 1.2 million cubic yards each. The potential exists for eight new cells depending upon future needs. These cells, classified as RCRA (Resource Conservation and Recovery Act) landfills, have a design life of approximately 20 to 30 years, which may be extended through the use of caps and/or engineered barriers.

While ex situ options may be available and effective over the short term, they are more expensive, labor-intensive, and have a greater potential for worker and environmental risk than in situ methods. Consequently, there are many drivers for the development of in situ treatment, monitoring, and characterization solutions.

One area in which there was an identified knowledge gap at Hanford was the rate of migration of radioactive cesium and other contaminants in the subsurface from tank leakage or waste cribs. Although it is strongly sorbed by the micaceous fraction of the soil, cesium appears to be moving faster toward the groundwater and, ultimately, the Columbia River than previously thought possible. The EMSP project "Fixation Mechanisms and Desorption Rates of Sorbed Cs in High Level Waste Contaminated Subsurface Sediment: Impacts to Future Behavior and In-Ground Stability" is a renewal of our 1997 EMSP project, "Mineral Surface Processes Responsible for the Decreased Retardation (or Enhanced Mobilization) of ${ }^{137}$ Cs from HighLevel Waste Tank Discharges." This project is investigating the geochemistry of cesium ion adsorption under conditions appropriate to high-level waste tank releases. The original work 
showed that high sodium concentrations in tank waste suppress all but the most selective cesium sorption sites on the frayed edges of micaceous particles and that the cesium migration depth is strongly controlled by the sodium concentration. The hydroxide and aluminate compounds in high-level waste may alter these sites chemically, leading to faster transport through the soil. The renewal will expand our understanding of this cesium mobility.

In fiscal year 1998, the Groundwater Vadose Zone (GW/VZ) integrated project was initiated to bring all of the issues that affect contamination of the soils and groundwater at the Hanford Site under one program. To begin the process, a roadmap was developed to determine the underlying gaps in knowledge needed to solve the problems associated with the contamination. As a result of this roadmapping effort, the EMSP agreed to allow the GW/VZ project assist in the preparation of the call for proposals in 1999, focusing the call on the problems identified with the roadmap. Three categories of EMSP projects were awarded at PNNL: 1) waste/sediment interactions and process modeling, 2) vadose zone field studies, advanced monitoring, and transport modeling, and 3) dense nonaqueous phase liquid (DNAPL) monitoring and remediation.

In the first category, waste/sediment interactions and process modeling, the goal of the research is to determine how the waste interacts with the soils, resulting in models to predict the holdup and release of contaminants. The surfaces of the minerals will interact with the contaminants, depending on the nature of the surfaces. The project "Technetium Attenuation in the Vadose Zone: Role of Mineral Interactions" is looking at the role of divalent iron-containing minerals in the reduction/precipitation of technetium in the environment. In addition to the initial reactions, the project will determine the stability of the precipitates to find out if natural attenuation in the soils will decrease the mobility of technetium, resulting in the potential savings in the cleanup. Another project looking into the reactions of surfaces is "The Influence of Calcium Carbonate Grain Coatings on Contaminant Reactivity in Vadose Zone Sediments." This project is examining how calcium carbonate on the surface of minerals will affect the interactions between soil particles and the contaminants. Carbonates will enhance the sorption of some contaminants (e.g., strontium-90 and cobalt-60) but may interfere with the interaction between the minerals and the species that will undergo reduction reactions (e.g., chromate and pertechnetate). Because many of the minerals in the soil are silicates, one of the concerns is how silicates dissolved by the leaking of the basic tank wastes into the subsurface will interact with some of the radionulides, potentially complexing them and increasing their mobility. A third project, "The Aqueous Thermodynamics and Complexation Reactions of Anionic Silica Species to High Concentration: Effects on Neutralization of Leaked Tank Wastes and Migration of Radionuclides in the Subsurface," is examining the effect of these dissolved silicates on contaminant mobility.

In addition to the minerals providing surfaces for oxidation/reduction reactions, one of the potential remediation technologies is to introduce a reductant into the environment to react with contaminants, resulting in immobilization of some of the contaminants of concern. DOE has been testing a process called in situ gaseous reduction (ISGR) in which hydrogen sulfide is added to a contaminant plume to convert it into a nonmobile and/or nonhazardous form. The kinetics and mechanisms of interaction of the reductant with the contaminants and surrounding 
minerals are being addressed in "Interfacial Reduction-Oxidation Mechanisms Governing Fate and Transport of Contaminants in the Vadose Zone," which PNNL co-leads with the New Mexico Institute of Mining and Technology.

The second category of projects supporting the GW/VZ project is the vadose zone field studies, advanced monitoring, and transport modeling. This work is focused mainly on looking at transport phenomena in actual field settings and the delineation of the contamination within the vadose zone. At the Hanford Site, numerous natural formations within the sediments may restrict the transport of contaminants or may provide preferential pathways that enhance the movement of the contaminants. The project "Influence of Clastic Dikes on Vertical Migration of Contaminants in the Vadose Zone at Hanford" is looking at the effect on flow of naturally occurring clastic dikes in the vadose zone to better understand the fate and transport of contaminants at the 200 West Hanford Tank Farms. In a more general treatment of the transport of contaminants, the project "Quantifying Vadose Zone Flow and Transport Uncertainties Using a Unified, Hierarchical Approach" is developing and demonstrating parameterized models of flow and transport in the heterogeneous vadose zone. This project will allow the elucidation of relationships between the quantity and spatial extent of characterization data and the accuracy and uncertainty of flow and transport predictions. Another important aspect in understanding the flow and transport of contaminants in the subsurface is the ability to delineate the contaminant plumes and identify the specific contaminants. At the Hanford Site, the species of most concern are radionuclides. The project "Radionuclide Sensors for Water Monitoring" is looking at chemistries for selective preconcentration/separation directly on or within the area of a radioactivity detector. The work involves assessing new materials and processes that can be incorporated into field-deployable sensors.

The final area of study in the GW/VZ project includes monitoring and remediation of DNAPLs, which are still a major problem for many private industries and governmental agencies, including DOE. Among the planned remediation technologies for these organic materials, in situ bioremediation offers advantages over physical treatments (e.g., pump and treat systems) due to the potential reduction in schedule, cost, public acceptance and the final achievable cleanup levels. However, this approach still has many uncertainties, such as the feasibility of this process on recalcitrant contaminants in deep vadose zones where microbial populations are low and discontinuous and how hydrologic features of the vadose zone control microbial processes. The project "Integrated Field, Laboratory, and Modeling Studies to Determine the Effects of Linked Microbial and Physical Spatial Heterogeneity on Engineered Vadose Zone Bioremediation" will provide an increased understanding of the effect of interacting hydrologic and microbiological processes that control the feasibility of engineered bioremediation of chlorinated compounds in the vadose zone. 
For more information, contact

Dr. Thomas L. Page

Manager, Environmental Management Subsector

Environmental Technology Division

Pacific Northwest National Laboratory

509-372-4550

or

Dr. Paul R. Bredt

Senior Research Scientist

Environmental Technology Division

Pacific Northwest National Laboratory

509-376-3777 


\section{Contents}

\subsection{Tank Waste Remediation}

Mechanisms and Kinetics of Organic Aging in High-Level Nuclear Waste.................. 1.1

Non-Invasive Diagnostics to Measure Physical Properties in High-Level Wastes ......... 1.5

New Metal Niobate and Silicotitanante Ion Exchangers: Development and

Characterization

Development of Fundamental Data on Chemical Speciation and Solubility for

Strontium and Americium in High-Level Waste: Predictive Modeling of Phase

Partitioning During Tank Processing.................................................................. 1.21

Computational Design of Metal Ion Sequestering Agents .................................... 1.27

Radiation Effects in Nuclear Waste Materials.......................................................... 1.33

\subsection{Soil and Groundwater Cleanup}

Fixation Mechanisms and Desorption Rates of Sorbed Cs in High-Level Waste Contaminated Subsurface Sediments: Implications to Future Behavior and In-Ground Stability

Technetium Attenuation in the Vadose Zone: Role of Mineral Interactions.

The Influence of Calcium Carbonate Grain Coatings on Contaminant Reactivity in Vadose Zone Sediments....

The Aqueous Thermodynamics and Complexation Reactions of Anionic Silica Species to High Concentration: Effects on Neutralization of Leaked Tank Wastes and Migration of Radionuclides in the Subsurface.

Interfacial Reduction-Oxidation Mechanisms Governing Fate and Transport of Contaminants in the Vadose Zone.

Influence of Clastic Dikes on Vertical Migration of Contaminants in the Vadose Zone at Hanford 
Quantifying Vadose Zone Flow and Transport Uncertainties Using a Unified,

Hierarchical Approach.

Radionuclide Sensors for Water Monitoring

Integrated Field, Laboratory, and Modeling Studies to Determine the Effects of Linked Microbial and Physical Spatial Heterogeneity on Engineered Vadose Zone Bioremediation 


\section{Tank Waste Remediation}




\section{Mechanisms and Kinetics of Organic Aging in High-Level Waste}

(Project Number: 65408)

\section{Principal Investigator}

Donald M. Camaioni

Pacific Northwest National Laboratory

P.O. Box 999, MSIN K2-57

Richland, WA 99352

509-375-2739 (phone)

509-372-6509 (fax)

donald.camaioni@pnl.gov

\section{Co-Investigators}

S. Tom Autrey

Pacific Northwest National Laboratory

P.O. Box 999, MSIN K2-57

Richland, WA 99352

509-375-3792 (phone)

509-375-6660 (fax)

tom.autrey@pnl.gov

Michel Dupuis

Pacific Northwest National Laboratory

P.O. Box 999, MSIN K8-91

Richland, WA 99352

509-376-4921 (phone)

509-376-0420

michel.dupuis@pnl.gov

Wendy Shaw

Pacific Northwest National Laboratory

P.O. Box 999, MSIN K2-57

Richland, WA 99352

509-375-5922 (phone)

509-375-6660 (fax)

wendy.shaw@pnl.gov 


\section{Research Objective}

The objective is to develop predictive models of organic degradation in high-level wastes (HLW). We make this information available to facility operators on the Hanford Site to support decision-making processes regarding safety, retrieval, and treatment issues. Emphasis is placed on the aging of organic complexants because they have direct impacts on safety issues such as the organic/nitrate salt and flammable gas problems. They also affect waste treatment efforts to separate radionuclides and reduce the volume of HLW.

\section{Research Progress and Implications}

This project, now in its third year, studies thermally- and radiolytically-induced reactions of organic compounds in waste simulants. The work on radiolytically induced reactions is coordinated closely with an EMSP project at the Notre Dame Radiation Laboratory. Together, we also explore the use of computational chemistry to characterize solution properties of intermediates in HLW.

\section{Thermally Induced Organic Aging}

At the start of the project, it was known that complexants with hydroxyl groups are thermally most reactive, nitrite ion is required, and aluminate is a catalyst. Other researchers have advanced a mechanism in which a nitritoaluminate species, e.g., $\mathrm{ONOAl}(\mathrm{HO})_{3}{ }^{-}$, catalyzes nitrosation of hydroxyl groups $\left[\mathrm{ROH}+\mathrm{ONOAl}(\mathrm{HO})_{3}{ }^{-} \rightarrow \mathrm{RONO}+\mathrm{Al}\left(\mathrm{OH}^{-}\right)_{4}\right]$ and the resulting nitrite ester decomposes to precusors of $\mathrm{H}_{2}$ and $\mathrm{N}_{2} \mathrm{O}$. We set out to measure the kinetics of aluminate catalysis of the reverse reaction, nitrosyl transfer from $\mathrm{RONO}$ to $\mathrm{OH}^{-}$, but found none. Subsequent work investigated the extent to which nitritoacetate degrades to gas precursors and ultimately to formate and oxalate at $60^{\circ}$ and $90^{\circ} \mathrm{C}$. This is key test of the nitrite ester mechanism because the kinetic order of aluminate ion in the rate law requires decomposition to be approximately 5 times faster than hydrolysis.

The results show that decomposition of nitritoacetate to gas precursors cannot be faster than hydrolysis, even at elevated temperatures. Therefore, organic nitrite esters and nitritoaluminates seem unlikely intermediates in the thermal reactions of complexants in the tank wastes, and alternative mechanisms must be considered. We suggest that the role of Al(III) may be to bind the charged glycolate dianion and nitrite anion, thereby lowering the coulombic contribution to the reaction barrier (Figure 1). In this way, Al serves as a bridge for electron transfer. Alternatively, or in addition, Al binding of the organic complexant may activate adjacent $\mathrm{C}-\mathrm{H}$ and $\mathrm{C}-\mathrm{C}$ bonds (Figure 1). 

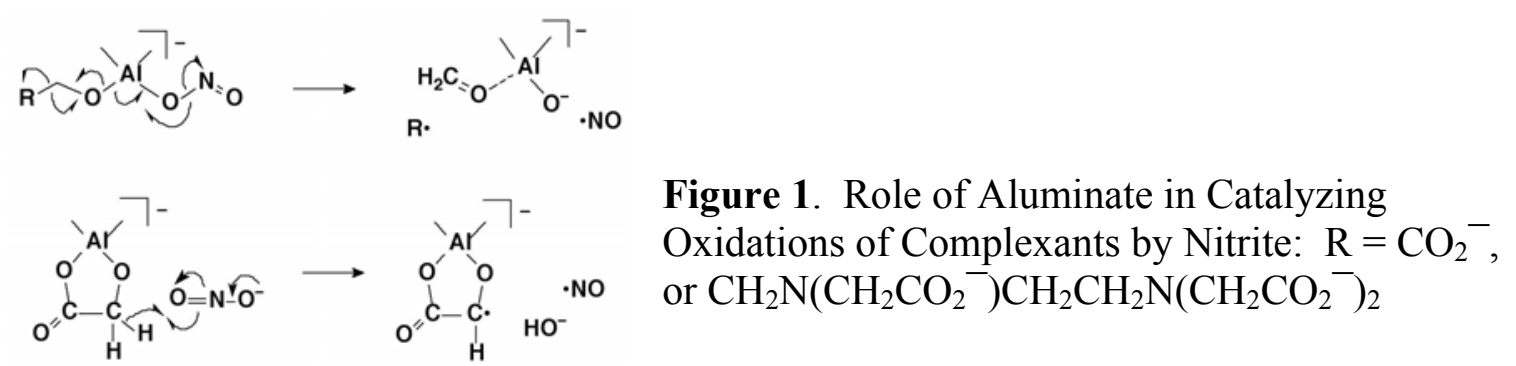

\section{Kinetic Simulation of Radiolytically Induced Reactions}

This work was performed in collaboration with the EMSP project at Notre Dame Radiation Laboratory and the Waste Tank Safety Program at Hanford. The underlying premise of the Notre Dame project is that the dominant radical in the irradiated HLW is the $\mathrm{NO}_{2}$ radical. This premise was verified early, and work since has focused on measuring rate constants, elucidating mechanisms for formation of $\mathrm{NO}_{2}$ and for its reactions with organic complexants, and modeling the overall kinetics. We contribute to the modeling effort under this project because our overall goal is to develop combined thermal and radiolytic predictive kinetics models.

Our collaboration led to a discovery that the strongly reducing radical, $\mathrm{NO}_{3}{ }^{2-}$, is produced by the strongly oxidizing $\mathrm{O}^{-}$radical $\left(\mathrm{NO}_{2}^{-}+\mathrm{O}^{-} \rightarrow \mathrm{NO}_{3}{ }^{2-}\right)$ that is a major water-fragmentation product at high $\mathrm{pH}$ typical for HLW. Prior to this discovery, $\mathrm{O}^{-}$was believed to react only via electron transfer leading to $\mathrm{NO}_{2}$ directly. This observation highlights the delicate balance between reducing and oxidizing reactions in HLW. The work involved fitting a complex multistep mechanism to the time-resolved electron spin resonance signal for $\mathrm{NO}_{3}{ }^{2-}$. Because most of the rate constants were known, it was possible to fit the kinetic behavior and derive a rate constant. We then extended the model to explain results for radiolysis of formate in HLW simulants. A useful feature of the model is that it allows extrapolation of results obtained from high-dose-rate laboratory studies to lower-dose-rate conditions typical of actual wastes.

\section{Theoretical Characterization of Intermediates}

A survey and benchmark calculations of methods for computing aqueous properties of molecules and ions were performed. Benchmark studies were deemed necessary because few radical and zwitterion radical species are usually included in the evaluation sets used in the development of these methods. We used solvation models based on a continuum dielectric representation of the solvent with the solute molecule inside a molecule-shaped cavity embedded in the continuum. In these models, the interaction of the solute with the solvent is modeled by means of effective charges induced by the solute electron density at the cavity boundary.

An important outcome of our benchmark comparisons of experiment and theory has been the development of a powerful semi-empirical protocol that allows computational results to be equated directly with experimental measurements. This protocol relies on accurate semiempirical estimates of the free energy of a proton in water, of a hydroxide ion in water, and for 
the standard hydrogen electrode. These two ions are known to be difficult to theoretically characterize because of their strong interaction with the solvent. Using semi-empirical estimates of their solvation free energies circumvents these difficulties. When combined with calculated solvation energies of a given species, these estimates lead to a direct correlation between the cavity radii and the experimental acidities or half-reaction potentials. This correlation puts us in a position to determine species-specific radii that reproduce experimental reaction energies for reactions involving these selected species. Although these species-specific radii may not be universally transferable, we believe that this protocol will provide a path to predicting accurately the chemistry of many species important to the redox chemistry in the HLW.

\section{Planned Activities}

In the remaining months of the current project, we will continue to investigate the role of $\mathrm{Al}$ in the thermally initiated organic aging and calibrate the computational solvation model to predict aqueous properties of oxoanions. A renewal proposal has been submitted. Under the renewal, we would extend the computational models to predict aqueous properties of organic complexes of technetium and its oxoanions in response to Hanford Site needs to understand the distribution of soluble technetium species in wastes.

\section{Information Access}

Cook AR, N Dimitrijevic, BW Dreyfus, D Meisel, LA Curtiss, and DM Camaioni. 2001.

"Reducing radicals in nitrate solutions. The $\mathrm{NO}_{3}{ }^{-}$system revisited." J. Phys. Chem. A, in press.

Meisel D, DM Camaioni, and TM Orlando. 2000. "Radiation and chemistry in nuclear waste:

The $\mathrm{NO}_{\mathrm{x}}$ system and organic aging." In Nuclear Site Remediation, on First Accomplishments of the Environmental Management Program, eds. PG Eller and WR Heineman, ACS Symposium Series 778, Chapter 21, pp. 342-361. American Chemical Society, Washington, D.C.

Camaioni DM and ST Autrey. 2000. "Thermochemical kinetic analysis of mechanism for thermal oxidation of organic complexants in high level waste." In Nuclear Site Remediation, on First Accomplishments of the Environmental Management Program, eds. PG Eller and WR Heineman, ACS Symposium Series 778, Chapter 21, pp. 342-361. American Chemical Society, Washington, D.C.

Fessenden RD, D Meisel, and DM Camaioni. 2000. "Addition of oxide radical ions $\left(\mathrm{O}^{-}\right)$to nitrite and oxide ions $\left(\mathrm{O}_{2^{-}}\right)$to nitrogen dioxide." J. Am. Chem. Soc 122:3773-3774.

Babad H and DM Camaioni. 2000. "The aging of organic chemicals in Hanford high-level wastes." In Proceedings of the Waste Management 2000 Symposium, February 27-March 2, 2000, Tucson, Arizona. WM Symposia, Inc., Tucson, Arizona. 


\section{Non-Invasive Diagnostics to Measure Physical Properties in High-Level Wastes}

(Project Number: 73827)

\section{Principal Investigator}

David M. Pfund

Pacific Northwest National Laboratory

P.O. Box 999, MS K7-15

Richland, WA 99352

(509) 375-3879 (phone)

david.pfund@pnl.gov

\section{Co-Investigator}

Robert L. Powell

University of California, Davis

Department of Chemical Engineering and Materials Science

One Shields Avenue

Davis, CA 95616-5294

rlpowell@ucdavis.edu

\section{Graduate Students}

Nihan Dogan, Ph.D.

Young Jin Choi, Ph.D. 


\section{Research Objective}

This work addresses the need for a technique that can determine the rheological properties of tank wastes under processing conditions and permit the monitoring and control of slurries during transport. This task consists of applying ultrasonic Doppler velocimetry and using it to measure the viscosity of flowing waste. We will use suspensions that simulate tank waste and will work under realistic flow conditions.

The work also includes demonstration of a tomographic measurement of solids loading and velocity profiles and an investigation of the utility of this approach in estimating mass flow rate. A tomographic system uses a number of independent line-of-sight measurements to solve the problem of simultaneously measuring the solids loading and velocity profiles within the pipe. Determining mass flow rate and weight percent solids requires knowledge of the speed-of-sound as a function of loading, and questions that will be addressed include effects of the particle size and density distributions.

Finally, this work will investigate the use of ultrasonic techniques to measure sedimentation interface and rate. A tool that could result from successful demonstration could be used to monitor sedimentation progress during in-tank pretreatment and waste processing.

\section{Research Progress and Implications}

After six months into this 3-year project, a new self-contained ultrasonic Doppler velocimeter has been designed and built. It is undergoing preliminary tests of the electronics. The new unit closes the gap between a laboratory experiment and a field-deployable unit instrument for measuring velocity profiles, volumetric flow rates, and viscosities. It combines the ultrasonic Doppler velocimeter instrument, acquisition of pressure and temperature measurements, and real-time calculations of viscosity versus shear rate into one package. The package is splash- and vibration-resistant, can withstand temperatures of $100^{\circ} \mathrm{C}$, and is suitable for installation in the field. New capabilities have been added to make it perform without the need for operator intervention or batch lab experiments:

- It is a dual (1-MHz and 5-MHz) frequency instrument and can choose the optimal frequency automatically.

- It provides a measure of signal quality at each radial position that is used to improve data analysis.

- It measures the sound speed of the fluid concurrently with velocity measurement, automatically compensating for temperature and composition variations and eliminating the need for a new calibration when a new fluid is being metered.

- It incorporates "phase-space undersampling," a technique that doubles the range of velocities the instrument can measure. 
The new ultrasonic Doppler velocimeter system will be tested with slurry simulants in our existing flow loop. The loop has been modified to improve operation at higher flow rates with viscous materials.

We have met twice with our collaborators from University of California, Davis. Pacific Northwest National Laboratory personnel visited the University of California, Davis in December 2000. We toured their laboratory and examined the nuclear magnetic resonance instrument that will be used to validate our ultrasonic Doppler velocimeter system. We spoke to students about their research schedule and made preliminary plans for them to work at Pacific Northwest National Laboratory during summer 2001. Davis personnel visited Pacific Northwest National Laboratory in May 2001, and planning for the summer research was completed.

\section{Planned Activities}

- Slurry simulants will be chosen for pipe flow experiments - May 2001.

- We will conduct tests of the new ultrasonic Doppler velocimeter system with slurry simulants - June 2001.

- Student research will be conducted using the ultrasonic Doppler velocimeter system summer 2001.

- A low-resolution ultrasonic tomography system (basically two copies of the ultrasonic Doppler velocimeter system) will be developed for detecting settling in pipe flow of slurries - fall 2001.

- Experiments to determine the critical settling velocity for slurries in pipe flow will be conducted - winter 2002.

- Nuclear magnetic resonance experiments will be conducted to determine the critical settling velocity for slurries in pipe flow (done at University of California, Davis in parallel with Pacific Northwest National Laboratory's ultrasonics-based measurements) - winter 2002. 


\title{
New Metal Niobate and Silicotitanate Ion Exchangers: Development and Characterization
}

(Project Number: 73748)

\author{
Principal Investigator \\ Yali Su \\ Pacific Northwest National Laboratory \\ P.O. Box 999, MSIN K8-93 \\ Richland, WA 99352 \\ (509) 376-5290 (phone) \\ (509) 376-5106 (fax) \\ ya.su@pnl.gov
}

Co-Investigators

Tina M. Nenoff

Sandia National Laboratories

P.O. Box 5800, MS 0710

Albuquerque, NM 87185-0709

(505) 844-0340 (phone)

(505) 845-9500 (fax)

tmnenof@sandia.gov

Alexandra Navrotsky

University of California, Davis

Department of Chemical Engineering and Materials Science

One Shields Avenue

Davis, CA 95616-8779

(530) 752-3292 (phone)

(530) 752-9307 (fax)

anavrotsky@ucdavis.edu

\section{Contributors}

M. L. Balmer*, Liyu Li, and Jim Young (PNNL)

May Nyman (SNL)

Hongwu Xu (UC Davis)

*Current address: Caterpillar Inc. Peoria, IL 61656-1875 


\section{Research Objective}

This project is a continuing EMSP project entitled "New Silicotitanate Waste Forms: Development and Characterization." In our original study, the phase selection and chemical durability of silicotitanates (including commercially available IE-911) as a function of temperature (500 to $1000^{\circ} \mathrm{C}$ ) was fully characterized by a combination of techniques including XRD, TEM, SEM, NMR, Raman spectroscopy, XAFS, XANES, and by thermodynamic studies. In addition, work on this program led to new discoveries not anticipated in the originally proposed research. Of particular importance was the discovery of a new ion exchange material that is selective for divalent cations under extreme conditions (e.g., acid solutions, competing cations), thus providing an alternative for removing $\mathrm{Sr}$ from mixed wastes. This material is converted easily by high-temperature, in situ heat treatment into a perovskite phase, which is also a major component of Synroc, a titanate ceramic waste form used for sequestration of high-level waste (HLW) from reprocessed, spent nuclear fuel.

This renewal project is based on the current needs in separation of cesium and strontium and the results obtained from our previous EMSP work. The purpose of this project is to deliver pertinent information that can be used to make rational decisions on selection of separation processes for cesium, strontium, and actinides. The objectives of this project are

1. to establish the structure/property relationship between inorganic ion exchanger materials and their ability to selectively separate divalent cations under extreme operating conditions - This includes optimizing stoichiometry, synthesis, and pretreatment conditions for metal niobate and silicotitanate ion exchangers for maximum strontium and actinide-surrogate selectivity.

2. to fully characterize the phase relationships, structures, and thermodynamic and kinetic stabilities of these new phases and their related condensed phases (as potential ceramic waste forms)

3. to understand the chemical and thermodynamic stabilities of silicotitanate ion exchangers based on an in-depth comprehension of local bonding configurations and thermochemistry

4. to apply fundamental understanding to tailoring an ion exchanger that is ideally suited for a DOE needs and therefore has the potential for short-term deployment in the DOE complex.

\section{Research Progress and Implications}

This report summarizes progress after 7 months of a 3-year project. Components of this report include 1) understanding the structural property relationship of new silicotitanates and niobate based ion exchangers and their related condensed phases (as potential ceramic waste forms);

2) investigating low temperature thermal and chemical stabilities of the CST when CST is 
contacted with SRS waste simulant; 3) determining the enthalpies of formation of new silicotitanates and niobate based ion exchangers and their related compounds by high temperature oxide melt solution calorimetry and 4) evaluating radiation stability of promising CST waste forms and their individual phases.

\section{Structure/Property Relationship Studies}

\section{Sandia Octahedral Molecular Sieves (SOMS)}

The SOMS phases are synthesized by hydrothermal treatment of sol mixtures containing water, sodium hydroxide, and hydrolyzed metal ( $\mathrm{Nb}, \mathrm{Ti}, \mathrm{Zr})$ alkoxides. A combination of analytical and spectroscopic data (DTA-TGA, ICP-AES, ${ }^{1} \mathrm{H}$ solid-state MAS NMR) led us to a welldefined composition of $\mathrm{Na}_{2} \mathrm{Nb}_{2-x} \mathrm{Ti}_{x} \mathrm{O}_{6-x}(\mathrm{OH})_{x} \cdot \mathrm{H}_{2} \mathrm{O}(x=0.4)$ for SOMS-1. This composition gave a satisfactory crystallographic solution with a discrepancy index of $\mathrm{R}_{1}=6.29 \%$ for the single crystal structure determination. To ensure the structure determination from the twinned crystal was representative of the bulk SOMS-1 sample, synchrotron x-ray powder diffraction data were collected and modeled by the Rietveld method. The excellent agreement obtained indicated that indeed the models derived from the twinned crystal and powder data are equivalent.

Our collaborators at SUNY-Stony Brook (J. Parise and colleagues) determined the structure of SOMS-1, which is shown in Figure 1. In this chemically constrained model, 3.2Ti and $12.8 \mathrm{Nb}$ atoms per unit cell are distributed randomly over two crystallographically distinct octahedral sites. The octahedrally coordinated $\mathrm{Na} 1$ and $\mathrm{Na} 2$ sites and the square planar $\mathrm{Na} 3$ site are fully occupied, a finding that is consistent with the 5:1:4 Na:Ti:Nb ratio observed by chemical analysis (ICP-AES). The geometry of the Na3 site is distorted by displacements away from the square planar position in the [010] direction, giving rise to $50 \%$ occupied sites $0.52 \AA$ above and below the plane of the oxygen atoms. Although such coordination is unusual for $\mathrm{Na}^{+}$, it is not unprecedented and is likely a compromise to the restricted coordination geometry provided by the framework. The ${ }^{23} \mathrm{Na}$ MAS NMR spectrum of SOMS-1 confirmed two Na geometries in a 3:1 population ratio (octahedral:distorted square planar) at $-8 \pm 1 \mathrm{ppm}$ (octahedral) and $-11 \pm$ 2 ppm (distorted square planar), respectively. (Dr. M. S. Maxwell at Lawrence Livermore National Laboratory performed the NMR research.)

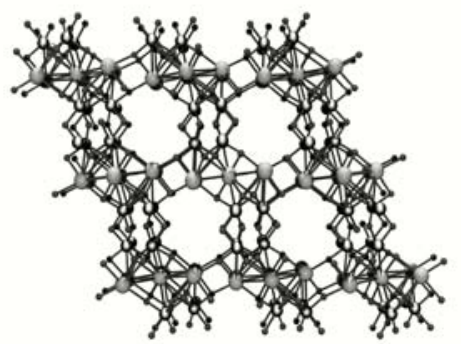

Figure 1. SOMS-1 Framework with Occluded $\mathrm{Na}+$ and Water Molecules Excluded from Channels for Ease of Viewing 
The SOMS phases exhibit ion-exchange selectivity for divalent cations over monovalent cations. The distribution coefficients $\left(\mathrm{K}_{\mathrm{d}}\right)$ for a variety of industrial metals, alkali metals, and alkaline earth metals on SOS-1 are summarized in Table 1. The divalent transition metals, $\mathrm{Ba}^{2+}$ and $\mathrm{Sr}^{2+}$, are completely removed from solution by SOMS-1. The selectivity of SOMS-1 for the alkali metals is extremely low when compared to its selectivity for alkaline earth metals. Our results indicate that the SOMS phases could be used for applications such as 1) removal of radioactive ${ }^{90} \mathrm{Sr}$ from Na-rich wastes or contaminated groundwater or soils containing natural abundance of $\mathrm{Mg}$ and $\mathrm{Ca}$ and 2) removal of divalent metals from industrial waste streams.

Table 1. Selectivity $\left(\mathrm{K}_{\mathrm{d}}\right)$ of Metals on SOMS-1

\begin{tabular}{|c|c|c|c|c|c|}
\hline Ion & $\mathrm{K}_{\mathrm{d}}(\mathrm{ml} / \mathrm{g})$ & Ion & $\mathrm{K}_{\mathrm{d}}(\mathrm{ml} / \mathrm{g})$ & Ion & $\mathrm{K}_{\mathrm{d}}(\mathrm{ml} / \mathrm{g})$ \\
\hline $\mathrm{Ba}^{2+}$ & $>99,800$ & $\mathrm{Cs}^{+}$ & 150 & $\overline{\mathrm{Pb}^{2+}}$ & 66,497 \\
\hline $\mathrm{Sr}^{2+}$ & $>99,800$ & $\mathrm{~K}^{+}$ & 95 & $\mathrm{Co}^{2+}$ & $>99,800$ \\
\hline $\mathrm{Ca}^{2+}$ & 2,300 & $\mathrm{Li}^{+}$ & 8 & $\mathrm{Ni}^{2+}$ & $>99,800$ \\
\hline \multirow[t]{2}{*}{$\mathrm{Mg}^{2+}$} & 226 & & & $\mathrm{Zn}^{2+}$ & $>99,800$ \\
\hline & & & & $\mathrm{Cd}^{2+}$ & $>99,800$ \\
\hline
\end{tabular}

The DTA-TGA analysis of SOMS- 1 with $10 \%$ of $\mathrm{Na}^{+}$exchanged for $\mathrm{Sr}^{2+}$ shows a weight loss in the temperature range from 100 to $300^{\circ} \mathrm{C}$. This loss corresponds to dehydration (calc. $7.6 \mathrm{wt} \%$, obs. $7.5 \mathrm{wt} \%$ ) followed by structure collapse to an amorphous state as observed by $\mathrm{x}$-ray diffraction. The exothermic transition at $550^{\circ} \mathrm{C}$ is associated with conversion to a perovskite form. Perovskite (titanate-based) is a major component in the well-known SYNROC ceramic waste form for high level radioactive waste storage and, thus, is a reliable commodity for stability in radioactive fields and in repository conditions. Micrographs of the $\mathrm{Sr}^{2+}$-loaded SOMS-1 and the perovskite reveal that this phase change takes place with remarkable morphology preservation, which indicates that remobilization of the strontium during heating is improbable.

Crystallographic structure refinement of variable Ti/Zr concentration SOMS were carried out in collaboration with J. Parise's group at SUNY-Stony Brook. Data shows a slight volume increase when compared to SOMS-1, as is expected since SOMS-1 has a $20 \%$ substitution of Ti on the $\mathrm{Nb}$ site, and this composition has almost no substitution on the $\mathrm{Nb}$ site: $\mathrm{Zr}_{0.016} \mathrm{Nb}_{0.984}(1.6 \% \mathrm{Zr}-$ SOMS), $R_{\text {Bragg }}=9.66 \%, V=1291.5 \AA_{. .}^{3}, a=17.038 \AA, b=5.031 \AA, c=16.488 \AA, \beta=113.97^{\circ}$ as compared to SOMS-1 (20\%-Ti SOMS) V = 1282.6 $\AA_{.,}^{3}, \mathrm{a}=16.939 \AA, \mathrm{b}=5.033 \AA, \mathrm{c}=16.466 \AA$, $\beta=114.00^{\circ}$.

\section{Ti-Substituted Pollucite, $\mathrm{CsTi}_{x} \mathrm{Al}_{1-\mathrm{x}} \mathrm{Si}_{2} \mathrm{O}_{6+x / 2}$}

The compositional series $\mathrm{CsTi}_{\mathrm{x}} \mathrm{Al}_{1-\mathrm{x}} \mathrm{Si}_{2} \mathrm{O}_{6+\mathrm{x} / 2}, 0 \leq \mathrm{x} \leq 1$, was synthesized by sol-gel method and was further investigated using $\mathrm{x}$-ray absorption and Raman spectroscopy at PNNL. The data indicate the formation of $\mathrm{TiO}_{5}$ edge-sharing polyhedra at relatively low Ti concentrations $(x=0.3)$. The presence of $\mathrm{TiO}_{5}$ polyhedra in the compositional series is evident from the intensity and energy value of characteristic pre-edge features in the near-edge structure of the x-ray absorption spectra (XANES), as shown in Figure 2. The edge-sharing geometry of the $\mathrm{TiO}_{5}$ polyhedra is 
determined by the analysis of the extended x-ray absorption fine structure (EXAFS), which indicates short $(3.0 \AA)$ Ti-Ti interatomic distances. The appearance of features in the Raman spectra at 645 and $717 \mathrm{~cm}^{-1}$, as shown in Figure 3, also supports the existence of edge-sharing Ti polyhedra at low levels of Ti substitution. The EXAFS and Raman results suggest a nonrandom pairing of $\mathrm{TiO}_{5}$ polyhedra on symmetrically equivalent sites and the formation of edge-sharing relationship between adjacent $\mathrm{TiO}_{5}$ polyhedra. The formation of an edge-sharing relationship between neighboring $\mathrm{TiO}_{5}$ Polyhedra is an unusual occurrence especially in framework aluminosilicates.

Observations by XAS that edge-sharing Ti configurations exist over the compositional range $0.3<\mathrm{x}<1$ may be useful in explaining the deviations from ideal mixing in the enthalpies of mixing and heats of formation that were observed at UC Davis over this same compositional region. That is, there is a configurational constraint imposed by the requirement that the $\mathrm{Ti}$ atoms are paired. In addition, local ordering on the symmetrically equivalent $\mathrm{Si}, \mathrm{Ti}, \mathrm{Al}$ site in the cubic structure is likely to result from both the requisite Ti pairing and the avoidance of Ti-O-Al and Al-O-Al bonding configurations.

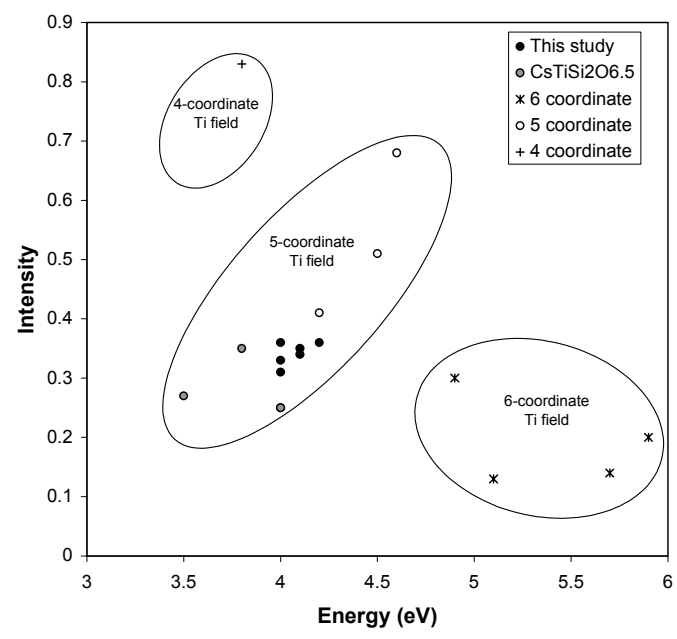

Figure 2. Plot of the energy position of the A2 pre-edge features versus intensity separates $\mathrm{Ti}$ bearing minerals into 4-, 5-, and 6-coordinate $\mathrm{Ti}$ fields. The $\mathrm{CsAl}_{1}{ }_{\mathrm{x}} \mathrm{Ti}_{\mathrm{x}} \mathrm{Si}_{2} \mathrm{O}_{6+\mathrm{x} / 2}$ samples studied here all fall within the 5-coordinate Ti field. The Ti samples from our earlier study are also plotted.

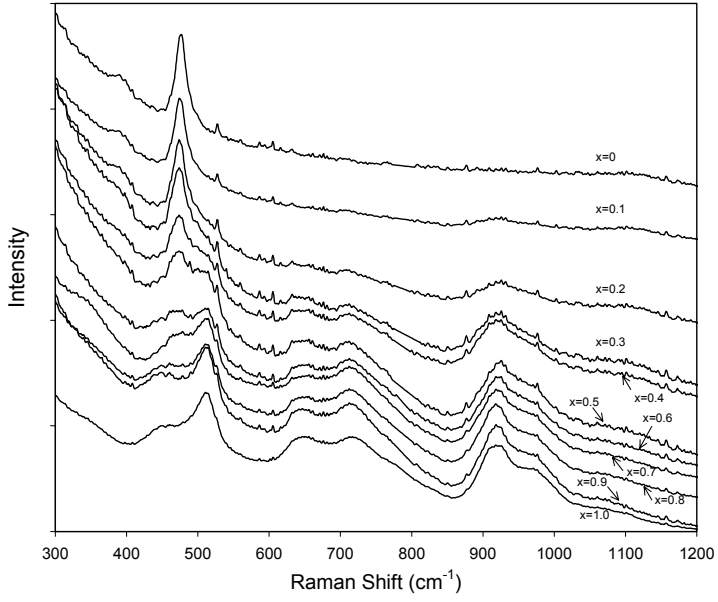

Figure 3. Raman spectra of the compositional series $\mathrm{CsAl}_{1}{ }_{\mathrm{x}} \mathrm{Ti}_{\mathrm{x}} \mathrm{Si}_{2} \mathrm{O}_{6+\mathrm{x} / 2}$ where $0<\mathrm{x}<1$. As the Ti content increases the intensity of the $474 \mathrm{~cm}^{-1}$ mode, which is characteristic of the $\mathrm{Si}-\mathrm{O}$ bonds in $\mathrm{CsAlSi}_{2} \mathrm{O}_{6}$, decreases. The Raman features at 645 and $717 \mathrm{~cm}^{-1}$ are indicative of an edge-sharing relationship between Ti-polyhedra.

\section{SNL-A Analogs; Cc-A2TiSi6O15; $A=K, R b, C s$}

Alkali silicotitanate ternary phases have been studied for a wide variety of applications including selective ion exchange and ceramic materials for storing nuclear waste. We present the synthesis and characterization of $\mathrm{Rb}_{2} \mathrm{TiSi}_{6} \mathrm{O}_{15}$ and $\mathrm{K}_{2} \mathrm{TiSi}_{6} \mathrm{O}_{15}$, which are structural analogs of the extremely thermodynamically stable $C c-\mathrm{Cs}_{2} \mathrm{TiSi}_{6} \mathrm{O}_{15}$ phase (also known as SNL-A) produced at Sandia National Laboratories. The Rb-analog is the first reported ternary oxide, rubidium silicotitanate 
phase. Both phases were synthesized in a pure form by hydrothermal treatment of oxide precursor mixtures seeded with SNL-A. They could not be synthesized without addition of the seed. Analysis included $\mathrm{x}$-ray powder diffraction, SEM/EDS, thermal analyses, and ${ }^{29} \mathrm{Si}$ MAS NMR.

In addition to their potential application as durable ceramic waste form materials, these new isostructural phases have presented the opportunity to relate phase stability to properties such as framework structure and chemical composition to structural complexity, ternary and quaternary oxide phases.

Rietveld refinement gave good structural models in the Cc space group with the following unit cell parameters: (Rb-analog) $\mathrm{V}=1357.9 \AA^{3}, a=12.736(2) \AA, b=7.3392(3) \AA, c=15.061(3) \AA$, $\beta=105.29(2)^{\circ}$; (K-analog) $\mathrm{V}=1318.5 \AA^{3}, a=12.570$ (2) $\AA, b=7.2534(3) \AA, c=15.082(3) \AA, \beta$ $=106.49(3)^{\circ}$. Direct correlation was observed between alkali radius $(\mathrm{Cs}>\mathrm{Rb}>\mathrm{K})$ with 1$)$ melting temperature and 2) unit cell parameters including volume $\left(\AA^{3}\right), a$-axis and $b$-axis $(\AA)$. The increasing $a$ - and $b$-axes with increasing alkali radius correlate with a "relaxation" of the silicate layer folds, which also is accompanied by an increase in average $\mathrm{Si}-\mathrm{O}-\mathrm{Si}$ bond angle.

\section{Chemical and Thermal Stabilities of CST}

An inorganic ion exchanger based on crystalline silicotitanate (CST), IONSIV ${ }^{\circledR}$ IE-911 ion exchanger (UOP LLC, Des Plaines, Illinois) currently is being considered for Cs separation at the Savannah River Site (SRS). While the performance of this ion exchanger has been well characterized under normal operating conditions, the stability of the material at slightly elevated temperatures, such as those that may occur in a process upset, is the subject of current evaluations at PNNL.

IE-911 was exposed to waste simulant at $55^{\circ} \mathrm{C}$ and $80^{\circ} \mathrm{C}$ for durations ranging from 1 to 60 days to determine if irreversible desorption of Cs from IE-911 occurs and, if so, the cause of the desorption and the time/temperature profiles over which it occurs. High Cs loading, high simulant/IE-911 ratio, and high-temperature heat treatment could cause irreversible Cs desorption. SEM results showed that a crystalline sodium aluminosilicate (nitrate cancrinite) phase precipitated on the surface of IE-911 shortly after exposure to simulant both at $55^{\circ} \mathrm{C}$ and at $80^{\circ} \mathrm{C}$. The morphology of the coating depends on the heat-treatment temperature, heat-treatment time, IE-911-to-simulant ratio, and simulant composition. IE-911 is not the major Si source for the aluminosilicate precipitation. The coating should not be the major reason for the irreversible Cs desorption because it was found on the surface of almost all the heat-treated IE-911 samples. Cancrinite-type aluminosilicate has large size openings in its structure so that Cs should be able to diffuse through these pores to IE-911 when the temperature was lowered. The mechanism for the irreversible Cs desorption is still under investigation. 


\section{Thermodynamic Studies Using High-Temperature Reaction Calorimetry}

\section{Crystal Chemistry and Energetics of Ti-Substituted Perovskites}

Using the sol-gel and solid-state sintering methods, two series of Ti-substituted niobate perovskites were synthesized at PNNL: 1$) \mathrm{NaTi}_{\mathrm{x}} \mathrm{Nb}_{1-\mathrm{x}} \mathrm{O}_{3-0.5 \mathrm{x}}(0 \leq \mathrm{x} \leq 0.3)\left(\mathrm{Ti}^{4+}+1 / 2 \mathrm{O}^{2-} \rightarrow\right.$ $\left.\mathrm{Nb}^{5+}\right)$; and 2) $(\mathrm{SrTi})_{x}(\mathrm{NaNb})_{1-\mathrm{x}} \mathrm{O}_{4}(0 \leq \mathrm{x} \leq 1)\left(\mathrm{Sr}^{2+}+\mathrm{Ti}^{4+} \rightarrow \mathrm{Na}^{+}+\mathrm{Nb}^{5+}\right)$.

Rietveld analysis of XRD data at UC-Davis shows that the symmetry of the structure in both series systematically increases with increasing Ti content (orthorhombic $\rightarrow$ tetragonal $\rightarrow$ cubic), as is consistent with the fact that the tolerance factor of perovskite becomes closer to unity as the Ti content increases. These compositionally driven phase transitions are analogous to those that occur in $\mathrm{NaNbO}_{3}$ at elevated temperatures. To further reveal the structural characteristics, such as the $\mathrm{O}$ vacancy positions in the first series, a set of high-resolution neutron diffraction data has been collected at Los Alamos National Laboratory, and detailed structure analysis using the Rietveld method is in process at UC-Davis.

The enthalpies of drop solution in molten $3 \mathrm{Na}_{2} \mathrm{O} \cdot 4 \mathrm{MoO}_{3}$ at $974 \mathrm{~K}$ were measured at UC-Davis by high-temperature reaction calorimetry, and the enthalpies of formation from constituent oxides have been determined using appropriate thermochemical cycles. With increasing $\mathrm{Ti}$ content, the enthalpy of formation in both series becomes less exothermic, implying a destabilizing effect of the substitution $\mathrm{Ti}^{4+}+1 / 2 \mathrm{O}^{2-} \rightarrow \mathrm{Nb}^{5+}$ and $\mathrm{Sr}^{2+}+\mathrm{Ti}^{4+} \rightarrow \mathrm{Na}^{+}+\mathrm{Nb}^{5+}$ on the perovskite structure (Figure 4). Further, in contrast to the trend in lattice parameters corresponding to the compositionally driven transitions, the enthalpic variation with composition is approximately linear. This behavior suggests that the enthalpies of these transitions are rather small, as is consistent with the small enthalpies for the transitions in $\mathrm{NaNbO}_{3}$ at high temperature.

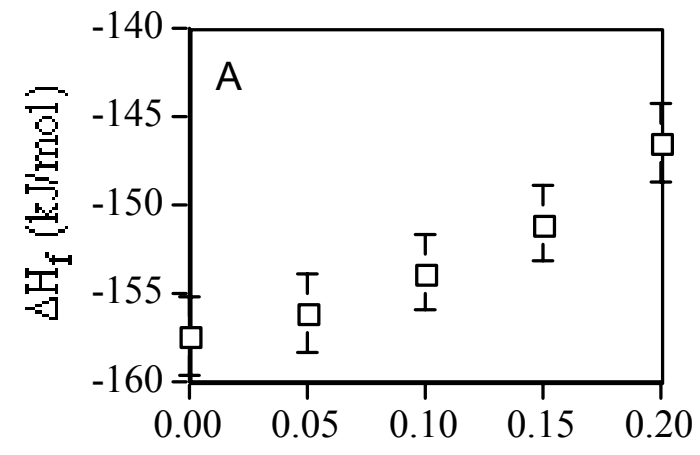

Mole Fraction (x)

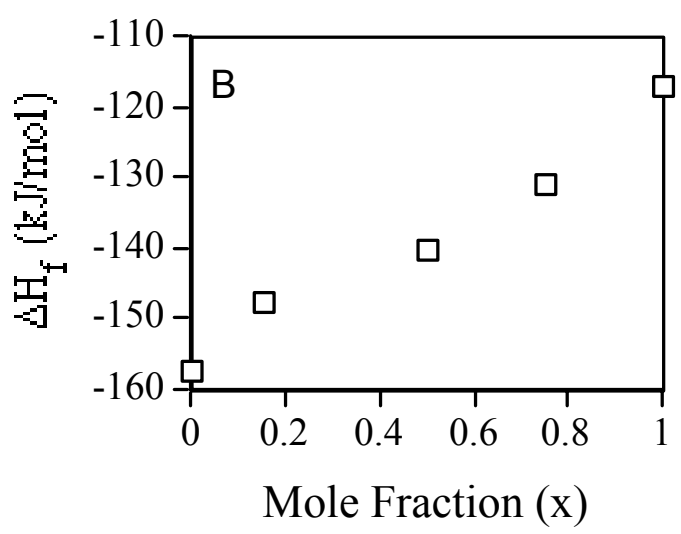

Figure 4. Variation in the Enthalpies of Formation of A) $\mathrm{NaTi}_{\mathrm{x}} \mathrm{Nb}_{1-\mathrm{x}} \mathrm{O}_{3-0.5 \mathrm{x}}$ and B) $(\mathrm{SrTi})_{\mathrm{x}}(\mathrm{NaNb})_{1-\mathrm{x}} \mathrm{O}_{4}$ from the Oxides as a Function of Composition 


\section{Energetics of $\mathrm{Na}_{5} \mathrm{TiNb}_{4} \mathrm{O}_{12} \cdot \mathrm{H}_{2} \mathrm{O}$ lon Exchanger}

Using the hydrothermal method, researchers at Sandia synthesized a series of octahedral molecular sieves that have high selectivity for radioactive $\mathrm{Sr}^{2+}$. Upon heating at high temperatures, these microporous ion exchangers convert to the thermodynamically stable and chemically durable dense perovskite phases. From drop solution calorimetry in sodium molybdate solvent at $974 \mathrm{~K}$, the enthalpy of formation from the oxides of the exchanger $\mathrm{Na}_{5} \mathrm{TiNb}_{4} \mathrm{O}_{12} \cdot \mathrm{H}_{2} \mathrm{O}$ and that of its corresponding perovskite phase $\mathrm{Na}_{5} \mathrm{TiNb}_{4} \mathrm{O}_{14.5}$ have been determined to be $-702.5 \pm 12.7$ and $-709.2 \pm 11.6 \mathrm{~kJ} / \mathrm{mol}$, respectively. Similar calorimetric measurements will be conducted at UC-Davis for Sr-containing phases. The goal of this study is to gain a fundamental understanding of the Na-Sr exchange energetics and the thermodynamics and kinetics of the potential waste forms.

\section{Radiation Stability Studies}

The thermally converted durable waste forms of Cs-loaded IE-911 have been developed at PNNL. The radiation effect on the thermally treated IE911 sample was investigated using JEOL 2010F transmission electron microscope by collaborators (B. Gu, L. Wang, and R. Ewing) at the University of Michigan. The operating voltage of the microscope was $200 \mathrm{kV}$. Multiple phases were identified based on chemical analysis with EDS and selected area diffraction patterns.

Electron beam irradiation has been performed on the two major phases in IE911 sample. As is indicated in the previous study, most of Cs appears to be in a $\mathrm{Cs}_{2} \mathrm{ZrSi}_{3} \mathrm{O}_{9}$ phase. The irradiation of this phase with a total electron dose of $2.3 \mathrm{E}+22$ electron $/ \mathrm{cm}^{2}$ did not cause any change in the diffraction pattern, thus indicating that the phase is quite stable under high dose of ionizing irradiation. Similar electron dose did not cause amorphization of the $\mathrm{Na}_{2} \mathrm{Ti}_{6} \mathrm{O}_{13}$ phase; however, the changes in the intensity of certain diffraction patterns imply that cation disordering may have occurred during the irradiation (Figure 5).
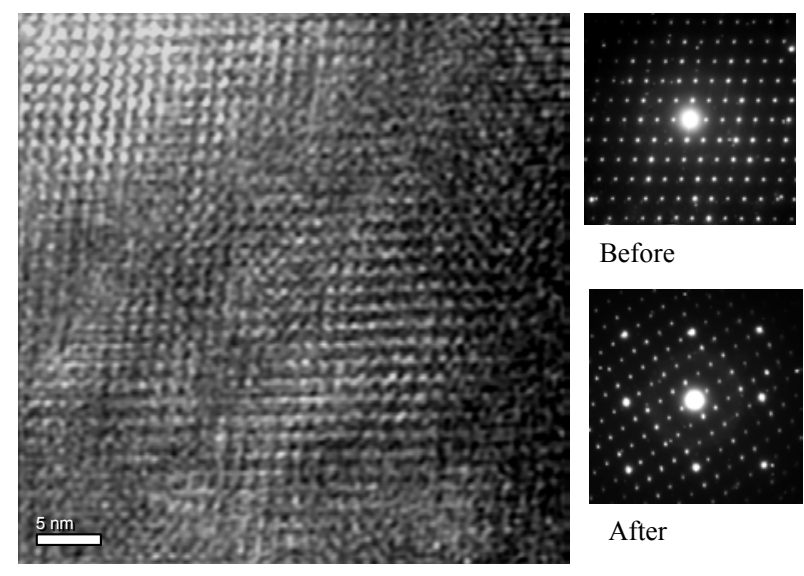

Before

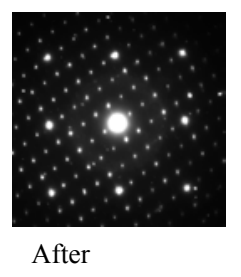

$\mathrm{Na}_{2} \mathrm{Ti}_{6} \mathrm{O}_{13}$ high resolution TEM

Figure 5. High Resolution TEM Images of $\mathrm{Na}_{2} \mathrm{Ti}_{6} \mathrm{O}_{13}$ and Electron Diffraction Patterns of Before and After $200 \mathrm{KeV}$ Electron Irradiation $\left(2.2 \mathrm{E}+22 \mathrm{e}^{-} / \mathrm{cm}^{2}\right)$ 


\section{Planned Activities}

Future work will concentrate on studying ionic potential versus $\mathrm{K}_{\mathrm{d}}$ (ion selectivity) to better understand divalent cation selectivity of $\mathrm{Na} / \mathrm{Nb} / \mathrm{Ti} / \mathrm{O}$ phases, determining precise atomic positions (particularly oxygen positions) of $\mathrm{A}_{2} \mathrm{TiSi}_{6} \mathrm{O}_{15}(\mathrm{~A}=\mathrm{K}, \mathrm{Rb}, \mathrm{Cs})$ by neutron diffraction to better understand changes in structural parameters with change in alkali cation, and synthesizing (Cs, Ba)/Si/Ti and (Cs, Ba)/Zr/Si compounds to understand the stability of Cs-containing compounds that radioactively decay to $\mathrm{Ba}$. In addition, the heat of formation of these compounds will be measured.

\section{Information Access}

\section{Publications}

Balmer ML, DE McCready, and Y Su. "Cubic-to-tetragonal phase transition in ti-substituted pollucite." Submitted to Journal of the American Ceramic Society.

Balmer ML, Y Su, H Xu, ER Bitten, DE McCready, and A Navrotsky. 2001. "Synthesis, structure determination and aqueous durability of $\mathrm{Cs}_{2} \mathrm{ZrSi}_{3} \mathrm{O}_{9}$." Journal of the American Ceramic Society 84:153-160.

Ness N, Y Su, and ML Balmer. 2001. "Evidence of edge-sharing $\mathrm{TiO}_{5}$ polyhedra in Tisubstituted pollucite, $\mathrm{CsTi}_{\mathrm{x}} \mathrm{Al}_{1-\mathrm{x}} \mathrm{Si}_{2} \mathrm{O}_{6+\mathrm{x} / 2}$." Journal of Physical Chemistry $B$ (in press).

Nyman M, A Tripathi, JB Parise, RS Maxwell, WTA Harrison, and TM Nenoff. 2001. "A new family of octahedral molecular sieves: Sodium Ti/Zr(IV) niobates." J. Amer. Chem. Soc. 123(7):1529-1530.

Nyman M, BX Gu, LM Wang, RC Ewing, and TM Nenoff. 2000. "Synthesis and characterization of a new microporous cesium silicotitanate (SNL-B) molecular sieve." Microporous and Mesoporous Materials 40:1-3, 115.

Nyman M, F Bonhomme, DM Teter, RS Maxwell, BX Gu, L Wang, RC Ewing, and TM Nenoff. 2000. "Integrated experimental and computational methods for structure determination and characterization of a new, highly stable cesium silicotitanate phase, Cs2TiSi6O15 (SNL-A)." Chem. Mater. 12:3449.

Nyman M, F Bonhomme, TM Nenoff. "First Rb-silicotitanate phase and its K-structural analog: New members of the SNL-A family (Cc-A2TiSi6O15; A=K, Rb, Cs)." Chem. Mater 2001, submitted.

$\mathrm{Xu} \mathrm{H}$, A Navrotsky, MD Nyman, and TM Nenoff. 2000. "Thermochemistry of microporous silicotitanate phases in the $\mathrm{Na}_{2} \mathrm{O}-\mathrm{Cs}_{2} \mathrm{O}-\mathrm{SiO}_{2}-\mathrm{TiO}_{2}-\mathrm{H}_{2} \mathrm{O}$ system." Journal of Materials Research $15: 815-823$. 
Xu H, A Navrotsky, ML Balmer, Y Su, and ER Bitten. 2001. "Energetics of substituted pollucites along the $\mathrm{CsAlSi}_{2} \mathrm{O}_{6}-\mathrm{CsTiSi}_{2} \mathrm{O}_{6.5}$ join: A high-temperature calorimetric study." Journal of the American Ceramic Society 84:555-560.

Xu H, Y Zhang, and A Navrotsky. 2001. "Enthalpies of formation of microporous titanosilicates ETS-4 and ETS-10." Microporous and Mesoporous Materials (in press).

\section{General Press Publications}

Tina M. Nenoff was photographed and interviewed for an article upcoming in National Geographic magazine on U.S. nuclear waste legacy research (publication scheduled for summer 2002).

SOMS was featured in Scientific American (web site), DOE Focus magazine, Sandia Lab News, and in numerous newspapers around the United States and in Europe (Associated Press article).

\section{U.S. Patent Submission}

"A New Class of Inorganic Molecular Sieves: Sodium Niobium Metal Oxides." TM Nenoff and M Nyman, July 2000.

\section{Presentations}

Nenoff TM and M Nyman. 2000. "A Novel Class of Niobate-based Molecular Sieves.” 16th International Canadian Catalysis Society Meeting, Banff, Alberta, Canada, June 2000.

Nenoff TM, M Nyman, A Tripathi, JB Parise, and RC Ewing. 2000. "SOMS: New Classes of $\mathrm{Na} / \mathrm{Nb} / \mathrm{X} / \mathrm{O}$ microporous and perovskite phases.” 2000 Fall MRS Meeting, Boston, Massachusetts.

Nenoff TM, M Nyman, A Tripathi, JB Parise, WTA Harrison, and RS Maxwell. 2001. "SOMS-Sandia octahedral molecular sieves: A new class of ion exchangers selective for the removal of $\mathrm{Sr}^{2+}$ from waste streams." 13th International Zeolite Conference, Montpelier, France, July 2001.

Nenoff TM, M Nyman, A Tripathi, JB Parise, WTA Harrison, RS Maxwell, and RC Ewing. 2001. "SOMS, new classes of $\mathrm{Na} / \mathrm{Nb} / \mathrm{X} / \mathrm{O}$ microporous and perovskite phases." Solid State Chemistry Gordon Conference, Oxford, United Kingdom, September 2001.

Nenoff TM, M Nyman, A Tripathi, JB Parise, WTA Harrison, RS Maxwell, and RC Ewing. 2001. "SOMS, a new class of molecular sieves with high selectivity for radioactive $\mathrm{Sr}^{+}$." Inorganic Chemistry Gordon Conference, Rhode Island, July 2001. 
Nenoff TM, M Nyman, ML Balmer, Y Su, L Li, A Navrotsky, and H Xu. 2001. "Synthesis and characterization of novel microporous materials (Cs,Na/Si/M/Ti/O)." Tanks Focus Area Midyear Review Meeting, Salt Lake City, Utah, March, 2001.

Su Y, L Li, J Young, and ML Balmer. 2001. "Chemical and thermal stability studies of Csloaded crystalline silicotitanate.” 222nd American Chemical Society National Meeting, Chicago, Illinois, August 2001. 


\section{Development of Fundamental Data on Chemical Speciation and Solubility for Strontium and Americium in High- Level Waste: Predictive Modeling of Phase Partitioning During Tank Processing}

(Project Number: 73749)

\section{Principal Investigator}

Andrew R. Felmy

Pacific Northwest National Laboratory

P.O. Box 999, MSIN K8-96

Richland, WA 99352

(509) 376-4079 (phone)

(509) 376-3650 (fax)

ar.felmy@pnl.gov

\section{Co-Investigators}

Gregory Choppin

The Florida State University

Department of Chemistry, B-164

Tallahassee, FL 32606-3006

(904) 644-3875 (phone)

(904) 644-8281 (fax)

Choppin@chemmail.chem.fsu.edu

David A. Dixon

Pacific Northwest National Laboratory

P.O. Box 999, MSIN K1-83

Richland, WA 99352

(509) 376-4999 (phone)

(509) 375-6631 (fax)

da.dixon@pnl.gov 


\section{Research Objective}

In this research program, Pacific Northwest National Laboratory and Florida State University are investigating the speciation of $\mathrm{Sr}$ and $\mathrm{Am} / \mathrm{Cm}$ in the presence of selected organic chelating agents (ethylenediaminetetraacetic acid [EDTA], N-(2-hydroxyethyl)ethylenediaminetriacetic acid [HEDTA], nitrilotriacetic acid [NTA], iminodiacetic acid [IDA], citrate, and oxalate) over ranges of hydroxide, carbonate, ionic strength, and competing metal ion concentrations present in high-level waste stored in tanks at Hanford and other U.S. Department of Energy (DOE) sites.

The project comprises integrated research tasks that approach the problem of chemical speciation using macroscopic thermodynamic measurements of metal-ligand competition reactions, molecular modeling studies to identify structures or complexes of unusual stability, and mass spectrometry measurements of complex charge/mass ratio that can be applied to mixed metalchelate systems. This fundamental information then is used to develop thermodynamic models designed to predict changes in chemical speciation and solubility resulting from various tankprocessing conditions. In this way we can develop new approaches that address fundamental problems in aqueous speciation and, at the same time, provide useful and practical information needed for tank waste processing.

\section{Problem Statement}

Current strategies for reducing the total volume of radioactive tank waste requiring disposal at Hanford and other DOE sites call for the development of methods that can be used to selectively dissolve and remove non-radioactive elements, such as $\mathrm{Al}, \mathrm{P}$, and $\mathrm{Cr}$, while retaining or precipitating the radioactive elements, including $\mathrm{Sr}$ and the actinide elements, in the tank sludge. This partitioning between solids and precipitates is fundamentally dependent on the chemical speciation of the elements present in the tank processing solutions. Of particular importance is separation of the radioactive and hazardous actinide elements and fission products from the sludge and supernatants, particularly from supernatants containing high concentrations of strong chelating agents that can act to dissolve the actinides and fission products as well as interfere with subsequent metal ion extraction processes. Specifically, the fundamental understanding of chemical speciation reactions gained from these studies will help us identify other potential mechanisms (e.g., competition, displacement, or other reactions) that could be used for removing $\mathrm{Sr}$ and $\mathrm{Am} / \mathrm{Cm}$ from organic chelates present in high-level tank waste.

\section{Research Accomplishments}

Beginning in October 1996, we initiated a research program on $\mathrm{Sr}$ and trivalent actinide speciation in high-ionic-strength, strongly basic solutions that contained organic chelates and competing metal ions. The chemical speciation and solubility data obtained from the initial studies then were used to develop aqueous thermodynamic models, based upon the Pitzer equations, for describing the chemical behavior of these elements in high ionic strength electrolytes. 
Initially, our studies focused on determining the effects of hydrolysis (hydroxide concentration) on the chemical speciation of Sr to high base concentration. Next, we studied the effects of carbonate complexation on $\mathrm{Sr}$ extending to high carbonate concentration. These initial studies completed our focus on the major inorganic complexants for $\mathrm{Sr}$ and formed the foundation for our subsequent studies of organic chelates.

In our studies of organic chelates, the effects of only one competing metal, $\mathrm{Ca}$, were studied. We also studied the effects of hydrolysis and carbonate complexation on the speciation and solubility of Ca because these factors must be known to develop an understanding of the effects of a competing metal ion.

Following completion of the Sr studies, we began our studies of the trivalent actinides using $\mathrm{Eu}(\mathrm{III})$ as the analog. These studies identified the potential importance of mixed metal-chelatehydroxide complexes in waste tank chemistry applications. Studies of Eu(III) complexation of EDTA and NTA under highly basic conditions were completed. No studies on the effects of competing metal ions on the speciation of the trivalent actinides were conducted.

In FY 00, our studies of the trivalent actinides were expanded to include the use of Cm(III). $\mathrm{Cm}$ (III) has a much higher fluorescence that $\mathrm{Eu}(\mathrm{III})$, so the studies could be conducted at much lower actinide concentrations $\left(\sim 10^{-8} \mathrm{~m}\right)$, thus avoiding the complications introduced by precipitation reactions.

\section{Studies on Cm Speciation}

Studies using Time Resolved Laser Luminescence Spectroscopy were performed on Cm(III) solutions over a range of base concentrations and in the presence of three organic chelates: HEDTA, citrate, and oxalate. All three of these chelating agents can be present in certain tank wastes (currently termed Envelope $\mathrm{C}$ wastes) that had received complex concentrate additions in the past. These three chelating agents had not been studied at high base concentrations to any significant degree in the past.

Figure 1 shows initial Time Resolved Laser Luminescence Spectroscopy results for these three chelating agents $(0.01 \mathrm{~m}$ chelate). As expected, at lower base concentration $(0.01 \mathrm{~m} \mathrm{NaOH})$, all three chelates are capable of complexing $\mathrm{Cm}(\mathrm{III})$. However, as the base concentration increases, the weakest of the three chelates is displaced, and only poorly fluorescent hydroxide complexes remain in solution. However, this is not the case for the citrate and HEDTA complexes, which remain in solution even to high base concentration $(7.5 \mathrm{~m})$. The significant shift in the peak maximum indicates changing speciation over this concentration range, which in turn is indicative of different numbers of hydroxides bound to the metal-chelate complexes. The results for citrate are particularly surprising since the single metal-chelate complexes for $\mathrm{Cm}$-citrate are significantly weaker than for the corresponding Cm-HEDTA complexes. These studies currently are being conducted over ranges of metal/ligand ratios and base concentrations to better identify the complexes formed and the thermodynamic characteristics of these species. 

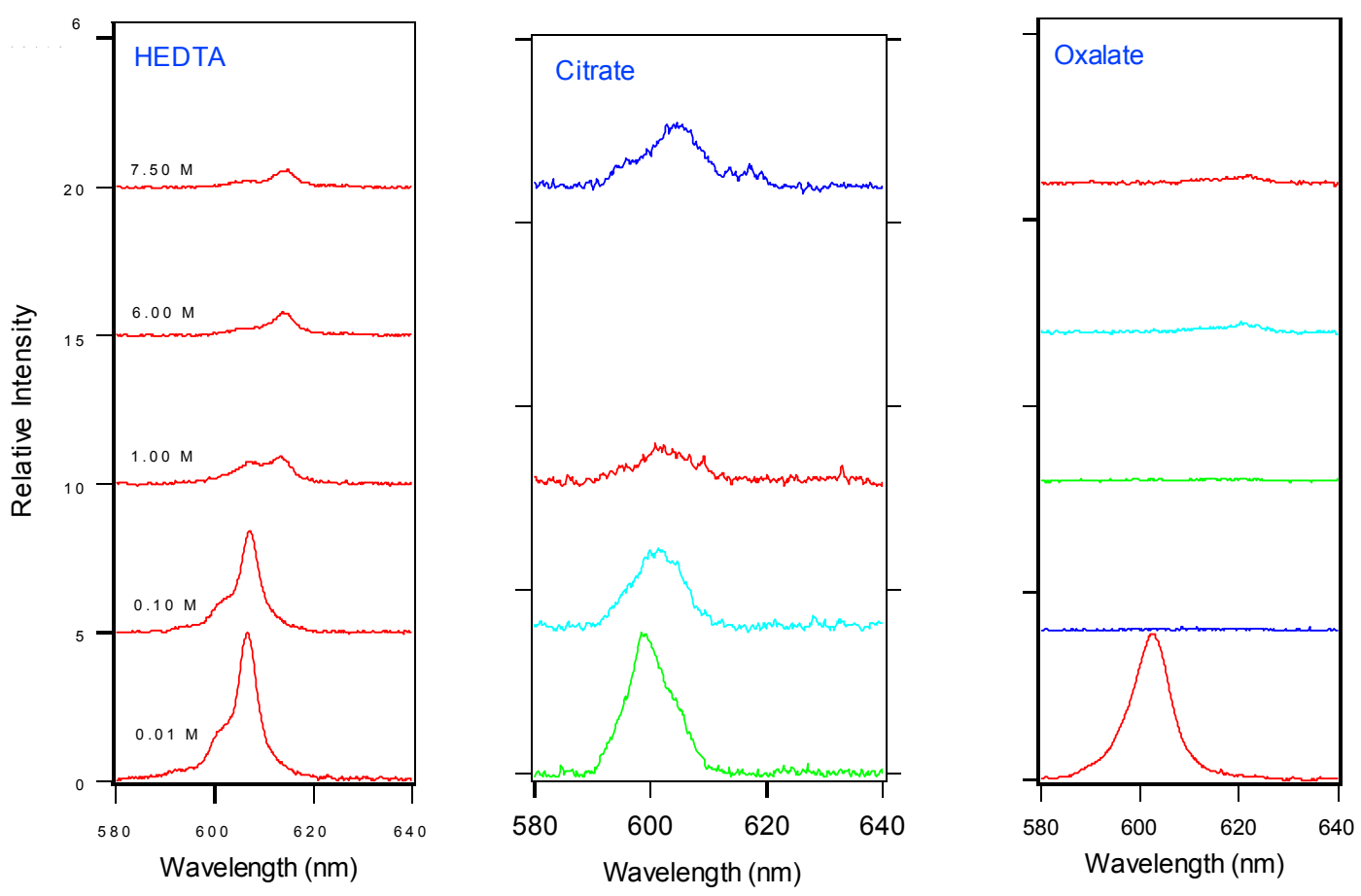

Figure 1. Emission Spectra of Cm(III) Complexes with HEDTA, Citrate, and Oxalate as a Function of $\mathrm{NaOH}$ Concentration

\section{Addition of Pitzer's Equations to ESP}

During FY01, considerable effort has been spent on incorporating new thermodynamic data (developed under EMSP and elsewhere) into the chemical processing models used at Hanford and other DOE sites. This effort was recognized with a news article in the CHG Hanford Site News on the addition of Pitzer's equations to the Environmental Simulation Program (ESP). This enhanced capability will allow all of the new thermodynamic data developed under EMSP to be used by the site contractors.

\section{Planned Activities}

In FY02, we plan to finalize our studies of the effects of base concentration on the organic chelates and then initiate studies of mixed metal-chelate-carbonate complexation. Carbonate is present in the Envelope $\mathrm{C}$ wastes at high concentrations along with the organic chelates. Although the inorganic speciation reactions of the trivalent actinides with carbonate are known to have high ionic strength, this is not the case in the presence of both carbonate and organic chelates. Like the mixed metal-chelate-hydroxide complexes, carbonate can attach to the central metal in the presence of the chelate because of the asymmetric charge (dipole moment) distribution about the metal-chelate complex. Studies of the competing metal Ni also will be initiated. 


\section{Information Access}

Felmy AR, Z Wang, DA Dixon, AG Joly, JR Rustad, and M J Mason. 2001. "The Aqueous Complexation of Eu(III) with Organic Chelates at High Base Concentration: Molecular and Thermodynamic Modeling Results.” ACS Symposium Series 778, Nuclear Site Remediation: The First Accomplishments of the Environmental Management Sciences Program. Chapter 5, pp. 63-82.

Felmy AR, H Cho, JR Rustad, DA Dixon, and GR Choppin. 2000. "The Aqueous Complexation Reactions of Anionic Silica Species to High Concentration." EMSP Vadose Zone Principal Investigators Workshop, November 28, 2000, Richland Washington.

Felmy AR, H Cho, GR Choppin, DA Dixon, GT MacLean, JR Rustad, Z Wang, and Y Xia. 2001. "Development of Accurate Chemical Models for Tank Waste Applications." Tanks Focus Area Mid-Year Review, March 12-15, 2001, Salt Lake City Utah.

Felmy AR, GT MacLean, and S Sanders. 2001. "Inclusion of Pitzer Activity Coefficient Model in ESP." Tanks Focus Area, Salt Dissolution Workshop, May 1-2, 2001, Richland, Washington.

Felmy AR, GT Maclean, and S Sanders. 2001. "The Addition of Pitzer's Equations to ESP." CHG Hanford Site News, May 2001, Richland, Washington.

AR Felmy and K Nagy are organizing the Accomplishments of the Environmental Management Sciences Program at the ACS National Meeting, August 26-31 2001, Chicago, Illinois. Six sessions are planned. 


\section{Computational Design of Metal Ion Sequestering Agents}

(Project Number: 54679)

\section{Principal Investigator}

Benjamin P. Hay

Pacific Northwest National Laboratory

P.O. Box 999

Richland, WA 99352

(509) 372-6239 (phone)

(509) 375-6631 (fax)

ben.hay@pnl.gov

\section{Co-Investigators}

David A. Dixon

Pacific Northwest National Laboratory

P.O. Box 999

Richland, WA 99352

(509) 372-4999 (phone)

(509) 375-6631 (fax)

david.dixon@pnl.gov

\section{Collaborators}

Robert T. Paine

Department of Chemistry

University of New Mexico

Albuquerque, NM 87131

(505) 277-1661 (phone)

(505) 277-2609 (fax)

rtpaine@unm.edu

Bruce A. Moyer

Oak Ridge National Laboratory

Oak Ridge, TN 37831

(423) 574-6718 (phone)

(423) 574-4939 (fax)

moyerba@ornl.gov
Brian M. Rapko

Pacific Northwest National Laboratory

P.O. Box 999

Richland, WA 99352

(509) 376-1571 (phone)

(509) 372-3861 (fax)

brian.rapko@pnl.gov

Kenneth N. Raymond

Department of Chemistry

University of California, Berkeley

Berkeley, CA 94720

(510) 642-7219 (phone)

(510) 486-5283 (fax)

raymond@garnet.berkeley.edu

Gilbert M. Brown

Oak Ridge National Laboratory

Oak Ridge, TN 37831

(423) 576-2756 (phone)

(423) 574-4939 (fax)

browngm1@ornl.gov 


\section{Research Objective}

Organic ligands that exhibit a high degree of metal ion recognition are essential precursors for developing separation processes and sensors for metal ions. Since the beginning of the nuclear era, much research has focused on discovering ligands that target specific radionuclides.

Members of the Group 1A and 2A cations (e.g., Cs, Sr, Ra) and the f-block metals (actinides and lanthanides) are of primary concern to DOE. Although there has been some success in identifying ligand architectures that exhibit a degree of metal ion recognition, the ability to control binding affinity and selectivity remains a significant challenge. The traditional approach for discovering such ligands has involved lengthy programs of organic synthesis and testing that, in the absence of reliable methods for screening compounds before synthesis, have resulted in much wasted research effort.

This project seeks to enhance and strengthen the traditional approach through computer-aided design of new and improved host molecules. Accurate electronic structure calculations are coupled with experimental data to provide fundamental information about ligand structure and the nature of metal-donor group interactions (design criteria). This fundamental information then is used in a molecular mechanics model (MM3) that helps us rapidly screen proposed ligand architectures and select the best members from a set of potential candidates. By using combinatorial methods, molecule building software has been developed that generates large numbers of candidate architectures for a given set of donor groups. The specific objectives of this project are

- to further understand the structural and energetic aspects of individual donor group-metal ion interactions and incorporate this information within the framework of MM3

- to further develop and evaluate approaches for correlating ligand structure with reactivity toward metal ions, in other words, screening capability

- to use molecule structure building software to generate large numbers of candidate ligand architectures for given sets of donor groups

- to screen candidates and identify ligand architectures that will exhibit enhanced metal ion recognition.

These new capabilities are being applied to ligand systems identified under other DOEsponsored projects where studies have suggested that modifying existing architectures will lead to dramatic enhancements in metal ion binding affinity and selectivity. With this in mind, we are collaborating with Professors R. T. Paine (University of New Mexico) and K. N. Raymond (University of California, Berkeley) and Drs. B. A. Moyer and G. M. Brown (Oak Ridge National Laboratory) to obtain experimental validation of the predicted new ligand structures. 
Successful completion of this study will yield molecular-level insight into the role that ligand architecture plays in controlling metal ion complexation and will provide a computational approach to ligand design.

\section{Research Progress and Implications}

This project is a renewal of the project "Architectural Design Criteria for f-Block Metal Sequestering Agents" that began in September 1996 and ended in May 2000. The original project, which combined theoretical and experimental approaches to investigate the interactions of amide ligands with metal ions, resulted in 28 presentations at meetings, workshops, and conferences, and 14 journal articles. Since then, there have been an additional six publications, with at least one more manuscript in preparation (vide infra), and four presentations. In addition, the PI is scheduled to present a seminar at Oak Ridge National Laboratory in June 2001 and has submitted abstracts for presentations at two conferences scheduled in August 2001. The followon research has led to the computational design of an improved architecture for a diamide sequestering agent for solvent extraction of lanthanides and actinides. Professor J. E. Hutchison (University of Oregon) has continued non-funded studies on this material. The new diamide has been prepared, and initial tests under solvent extraction conditions reveal a 4 order of magnitude increase in the europium distribution constant over that obtained with N,N,N',N'-

tetrahexylmalonamide. This finding suggests that application of our design criteria was successful.

Funding for this project was renewed on October 2000, and this report summarizes progress after 7 months of a 3-year period. The renewed scope is limited to theoretical research with an emphasis on both the development and application of computational methods for ligand design. One goal is to expand design capability to ligands bearing other types of donor groups including amines, carboxylates, and aminocarboxylates. To assist in this research, postdoctoral associate Tom Klinckman, recently graduated from Professor Tom Cundari's group at the University of Memphis, was recruited in October 2000 and arrived at Pacific Northwest National Laboratory in January 2001. Investigations of the structural and energetic aspects of these ligands and their metal complexes with lanthanides and actinides are now underway. These investigations include electronic structure calculations on structural components of polydentate aminocarboxylates, such as N,N,N',N'-tetramethyl-ethylenediamine and N,N-dimethylglycine; electronic structure calculations on metal complexes with unidentate donor groups, such as acetate and trimethylamine; and a statistical analysis of x-ray structural data retrieved from the Cambridge Structural Database.

\section{Planned Activities}

- Develop an extended molecular mechanic model for amines, carboxylates, and aminocarboxylates and their f-block metal ion complexes.

- Demonstrate a capability to screen aminocarboxylate architectures for metal complex stability through correlation of structure-stability data available in the literature. 
- Couple molecular mechanics screening capability with structure building software.

- Apply computational tools to identify improved host architectures in collaboration with experimental research groups. The principal investigator plans on-site visits with experimental collaborators. The first visit is scheduled for June 2001 at Oak Ridge National Laboratory.

\section{Information Access}

\section{Publications Since May 2000}

Hay BP and RD Hancock. 2001. "The role of donor group orientation as a factor in metal ion recognition by ligands." Coord. Chem. Rev. 212:61-78.

Hay BP, BM Rapko, DA Dixon, R Vargas, J Garza, RD Rogers, and GA Broker. "Structural criteria for the rational design of selective ligands. 4. Metal ion complexation by diamide chelate rings." manuscript in preparation.

Lumetta GJ, BK McNamara, BM Rapko, RL Sell, RD Rogers, GA Broker, and JE Hutchison. 2000. "Synthesis and characterization of mono- and bis-(tetraalkyl-malonamide)uranium(VI) complexes." Inorganica Chimica Acta 309:103-108.

Rao L, P Zanonato, P Di Bernardo, and A Bismondo. 2000. "Calorimetric and spectroscopic studies of $\mathrm{Eu}(\mathrm{III})$ complexation with tetramethylmalonamide and tetramethylsuccinamide in acetonitrile and dimethylsulfoxide." Inorg. Chim. Acta 306:49-64.

Rapko BM, BK McNamara, GJ Lumetta, RD Rogers, GA Broker, and BP Hay. 2000. "Coordination of lanthanide ions containing non-coordinating counteranions with N,N,N',N'tetramethylsuccinamide (TMSA). I. Preparation and characterization of [(TMSA) $\left.)_{4} \mathrm{Ln}\right][\mathrm{A}]_{3}, \mathrm{~A}=$ $\mathrm{ClO}_{4}^{-}, \mathrm{CF}_{3} \mathrm{SO}_{3}^{-}$." Inorg. Chem. 39:4858-4867.

Vargas R, J Garza, DA Dixon, and BP Hay. 2000. "Conformational analysis of N,N,N',N'tetramethylsuccinamide: Importance of $\mathrm{C}-\mathrm{H} \cdots O \mathrm{O}$ hydrogen bonds?" J. Phys. Chem. A 104:51155121.

Vargas R, J Garza, DA Dixon, and BP Hay. 2000. "How Strong is the C(alpha)-H $\cdots \cdot \mathrm{O}=\mathrm{C}$ Hydrogen Bond?" J. Am. Chem. Soc. 122:4750-4755 and highlighted in C\&E News, 2000, Volume 78, Page 15 News of the Week article "Protein Folding. Weak Hydrogen Bonds in Peptide Backbones May Play Significant Role.” 


\section{Presentations Since May 2000}

BP Hay, DA Dixon, and BM Rapko. 2001. "Computational design of metal ion sequestering agents." Abstract submitted to the EMSP Symposium, $222^{\text {nd }}$ American Chemical Society National Meeting to be held in Chicago, Illinois.

Gilbertson RD, BM Rapko, BP Hay, JE Hutchison, and TJR Weakly. 2001. "Synthesis of a conformationally constrained malonamide and its coordination chemistry with uranyl nitrate." $221^{\text {st }}$ American Chemical Society National Meeting, San Diego, California.

Hay BP, DA Dixon, and BM Rapko. 2001. "Computational design of metal ion sequestering agents (EMSP 54679).” Tanks Focus Area (TFA) FY 2001 Midyear Review, Salt Lake City, Utah.

Hay BP. 2000. "Building a better mousetrap: ligand design with molecular mechanics." American Chemical Society, Pacifichem 2000 Meeting in Honolulu, Hawaii.

Hay BP. 2001. "HostBuilder: A combinatorial structure generator for host discovery." Separations Group Seminar to be held at Oak Ridge National Laboratory, Oak Ridge, Tennessee.

Klinckman TR, DA Dixon, and BP Hay. 2001. "An MM3 force field for metal complexes with amines, carboxylates, and aminocarboxylates." Abstract submitted to the Inorganic Poster Session, $222^{\text {nd }}$ American Chemical Society National Meeting to be held in Chicago, Illinois.

Lumetta GJ, BK McNamarra, BM Rapko, RD Rogers, GA Broker, and JE Hutchison. 2001. "Extraction of U(VI) with malonamides: what's really going on?" $221^{\text {st }}$ American Chemical Society National Meeting, San Diego, California. 


\section{Radiation Effects in Nuclear Waste Materials \\ (Project Number: 73750)}

\section{Principal Investigator}

William J. Weber

Pacific Northwest National Laboratory

P.O. Box 999, MSIN K8-93

Richland, WA 99352

(509) 376-3644

bill.weber@pnl.gov

\section{Co-Investigators}

Lumin Wang

Nuclear Engineering \& Radiological Sciences

The University of Michigan

2355 Bonisteel Boulevard

Ann Arbor, MI 48109-2104

(734) 647-8530

lmwang@umich.edu

Nancy J. Hess

Pacific Northwest National Laboratory

P.O. Box 999, MSIN P7-50

Richland, WA 99352

(509) 376-9808

nancy.hess@pnl.gov

B. Peter McGrail

Pacific Northwest National Laboratory

P.O. Box 999, MSIN K6-81

Richland, WA 99352

(509) 376-9193

pete.mcgrail@pnl.gov 


\section{Research Objective}

The objective of this project is to develop a fundamental understanding of radiation effects in glasses and ceramics, as well as the influence of solid-state radiation effects on aqueous dissolution kinetics. This study will provide the underpinning science to develop improved glass and ceramic waste forms for the immobilization and disposition of high-level tank waste, excess plutonium, plutonium residues and scrap, other actinides, and other nuclear waste streams. Furthermore, this study will develop predictive models for the performance of nuclear waste forms and stabilized nuclear materials. The research focuses on the effects of alpha and beta decay on defect production, defect interactions, diffusion, solid-state phase transformations, and dissolution kinetics. Plutonium incorporation, ion-beam irradiation, and electron-beam irradiation are used to simulate the effects of alpha decay and beta decay on relevant glasses and ceramics in experimental studies. Computer simulation methods are used to provide an atomic-level interpretation of experimental data and continuum-level modeling.

\section{Research Progress and Implications}

This report summarizes progress after 3 months of a 3 -year project. While this is a renewal project, there has been a lapse of 18 months without funding. Since continuity of the research was disrupted, there has been no ongoing carryover research as normally would have been expected. Thus, most of the accomplishments in this short time to date have been in the recovery of radioactive samples from the previous project, reassembly of the research team, experimental design, and preparation of a large number of ceramic and glass samples for irradiation testing this year and next.

The co-investigator at the University of Michigan has yet to receive funding; however, a research plan has been developed, and samples are being prepared for shipment to the University of Michigan as soon as they receive funding to begin their research task.

\section{Planned Activities}

\section{Alpha-Decay Effects in Glasses and Ceramics}

It is critical to determine the local changes in structure of the boron in the three Pu-doped glasses that have been studied previously under this project, as this may be important to understanding the changes in dissolution kinetics. These measurements will be carried out using the Advanced Light Source. The presence of any molecular oxygen that may have been produced in these glasses because of radiation-induced decomposition will be probed using Raman and infrared photoluminescence.

Since some dissolution measurements were performed on the Pu-doped glasses immediately after preparation in 1982, the same dissolution measurements will be performed on these glasses in their current radiation-damaged state for comparison. In addition, we will perform a comprehensive set of dissolution kinetics experiments with the ${ }^{239} \mathrm{Pu}$-doped glass (lightly 
damaged) and the ${ }^{238} \mathrm{Pu}$-doped glass (highly damaged) using the single-pass flow-through (SPFT) test method to measure the forward reaction rate of these glasses as a function of temperature and $\mathrm{pH}$.

An annealing study of the amorphous ${ }^{238} \mathrm{Pu}$-zircon will be carried out at 600,700 , and $800^{\circ} \mathrm{C}$, and we will perform XAS measurements, as before, to understand the early stages of annealing. This recovery process is critically important to developing and validating long-term predictive models. In addition, we will use Raman spectroscopy to measure the decrease in width of the antisymmetric stretching vibrational band of the $\mathrm{SiO}_{4}$ tetrahedra in the $\mathrm{Pu}$-zircons as a function of annealing temperature.

\section{Electron and Ion Irradiation Studies}

The University of Michigan will lead studies on using electron beams and light-ion $\left(\mathrm{H}^{+}, \mathrm{He}^{+}\right)$ beams to study the effects of ionization (from beta and alpha decay) on the structure and stability of glasses. Heavy-ion irradiation will also be used to simulate the radiation effects induced by alpha-recoil particles. During the ion-beam irradiation, an in situ transmission electron microscopy study will be performed using the IVEM-Tandem facility at Argonne National Laboratory.

Ion-irradiation experiments conducted at Pacific Northwest National Laboratory will employ a range of ions in continued studies of irradiation effects in ceramics that may be relevant to the Nuclear Materials Focus Area and for special waste streams (e.g., Cs immobilization). Phases of interest include apatite, zircon, silicotitanate, rare-earth titanates, and rare-earth zirconates. Irradiations will be performed on high-density sintered samples. We will perform small-angle $\mathrm{X}$-ray diffraction and dissolution measurements on bulk samples.

\section{Information Access}

Weber WJ. 2000. Radiation Effects in Nuclear Waste Materials, Final Report, EMSP Project Number 54672 (http://emsp.em.doe.gov/products.htm).

Begg BD, NJ Hess, WJ Weber, R Devanathan, JP Icenhower, S Thevuthasan, and BP McGrail. 2001. "Heavy-Ion Irradiation Effects on Structures and Acid Dissolution of Pyrochlores," Journal of Nuclear Materials 288[2-3]:208-216. 


\section{Soil and Groundwater Cleanup}




\section{Fixation Mechanisms and Desorption Rates of Sorbed Cs in High-Level Waste Contaminated Subsurface Sediments: Implications to Future Behavior and In-Ground Stability}

(Project Number: 73758)

\section{Principal Investigator}

John M. Zachara

Pacific Northwest National Laboratory

P.O. Box 999, MSIN K8-96

Richland, WA 99352

(509) 376-3254 (phone)

(509) 376-3650 (fax)

john.zachara@pnl.gov

\section{Co-Investigators}

James P. McKinley

Pacific Northwest National Laboratory

P.O. Box 999, MSIN K3-61

Richland, WA 99352

(509) 375-6861 (phone)

(509) 375-6954 (fax)

james.mckinley@pnl.gov

Calvin C. Ainsworth

Pacific Northwest National Laboratory

P.O. Box 999, MSIN K3-61

Richland, WA 99352

(509) 375-2670 (phone)

(509) 375-6954 (fax)

calvin.ainsworth@pnl.gov

R. Jeff Serne

Pacific Northwest National Laboratory

P.O. Box 999, MSIN K6-81

Richland, WA 99352

(509) 376-8429 (phone)

(509) 376-5368 (fax)

jeff.serne@pnl.gov 


\section{Research Objective}

The high-yield fission product ${ }^{137} \mathrm{Cs}$ is a major contaminant of the vadose zone at Hanford and other DOE sites. Over $100 \mathrm{kCi}$ of ${ }^{137} \mathrm{Cs}$ was discharged to the vadose zone in the S-SX tank farm at Hanford through the leakage of high-level waste from tanks SX-108 and SX-109.

Although ${ }^{137} \mathrm{Cs}$ is strongly sorbed by subsurface sediments, certain waste characteristics, such as high $\mathrm{Na}^{+}$, can expedite its migration and reduce its retardation to low values.

This project is focused on defining the in-ground geochemistry of sorbed ${ }^{137} \mathrm{Cs}$ released from high-level waste tanks, so that better future projections can be made of Cs mobility in the vadose zone. The project will study Cs-contaminated subsurface sediments from various Hanford tank farms to 1) determine the mineralogic and surface site residence of sorbed Cs in contaminated sediments varying in current Cs content and original waste composition, 2) establish geochemical factors and processes controlling Cs desorbability and desorption kinetics from contaminated sediment and Cs-enriched sediment particles, and 3) define and parameterize a kinetic model for Cs desorption that incorporates multi-site behavior and heterogeneous intraparticle Cs distribution.

\section{Research Progress and Implications}

This project is in its first year since its renewal. A series of eight samples, ranging in ${ }^{137} \mathrm{Cs}$ concentration (from $10^{5}$ to $10^{8} \mathrm{pCi} / \mathrm{g}$ ), was obtained from the Hanford River Protection Program by the placement of a slant borehole beneath leaked tank SX-108 in the S-SX tank farm. This core was the first ever collected at Hanford from the zone immediately beneath a leaked singleshell tank. Two of the samples that contained $10^{8} \mathrm{pCi} / \mathrm{g}-{ }^{137} \mathrm{Cs}$ were the hottest geologic materials ever brought to the ground surface at the Hanford Site.

Samples of the eight sediments were dispersed on slides and contacted with a phosphor-imaging slide to identify mineral grains containing ${ }^{137} \mathrm{Cs}$. The mounted grains were then manipulated and isolated into mineral fractions containing medium-high, low, and non-detectable ${ }^{137} \mathrm{Cs}$ concentrations. Grains in each of these fractions were then identified by a combination of methods, including X-ray diffraction and electron microprobe. The mineral particles containing high levels of ${ }^{137} \mathrm{Cs}$ were invariably micas. Those particles containing small levels of radioactivity were characteristically quartz grains that showed surface precipitates of zeolites that resulted from waste-sediment geochemical interaction (Figure 1). Particles without radioactivity included feldspars and clean quartz grains. These results allowed us to confirm that primary sorbents for ${ }^{137} \mathrm{Cs}$ in the waste-impacted sediments were micas (biotite and muscovite). Many persons had speculated that harsh chemical characteristics of the tank waste [for example, high $\mathrm{OH}^{-}$and $\left.\mathrm{Al}(\mathrm{OH})_{4}{ }^{-}\right]$would induce the formation of secondary minerals (zeolites and aluminosilicates) that might further sequester ${ }^{137} \mathrm{Cs}$. We saw no evidence that such phenomenon was widespread.

Samples of four ${ }^{137} \mathrm{Cs}$-containing sediments from the SX-108 borehole that varied in distance from the tank, $\mathrm{pH}$, and ${ }^{137} \mathrm{Cs}$ concentration were placed in $\mathrm{Na}^{+}, \mathrm{Rb}^{+}, \mathrm{K}^{+}$, and $\mathrm{NH}_{4}{ }^{+}$electrolytes of 


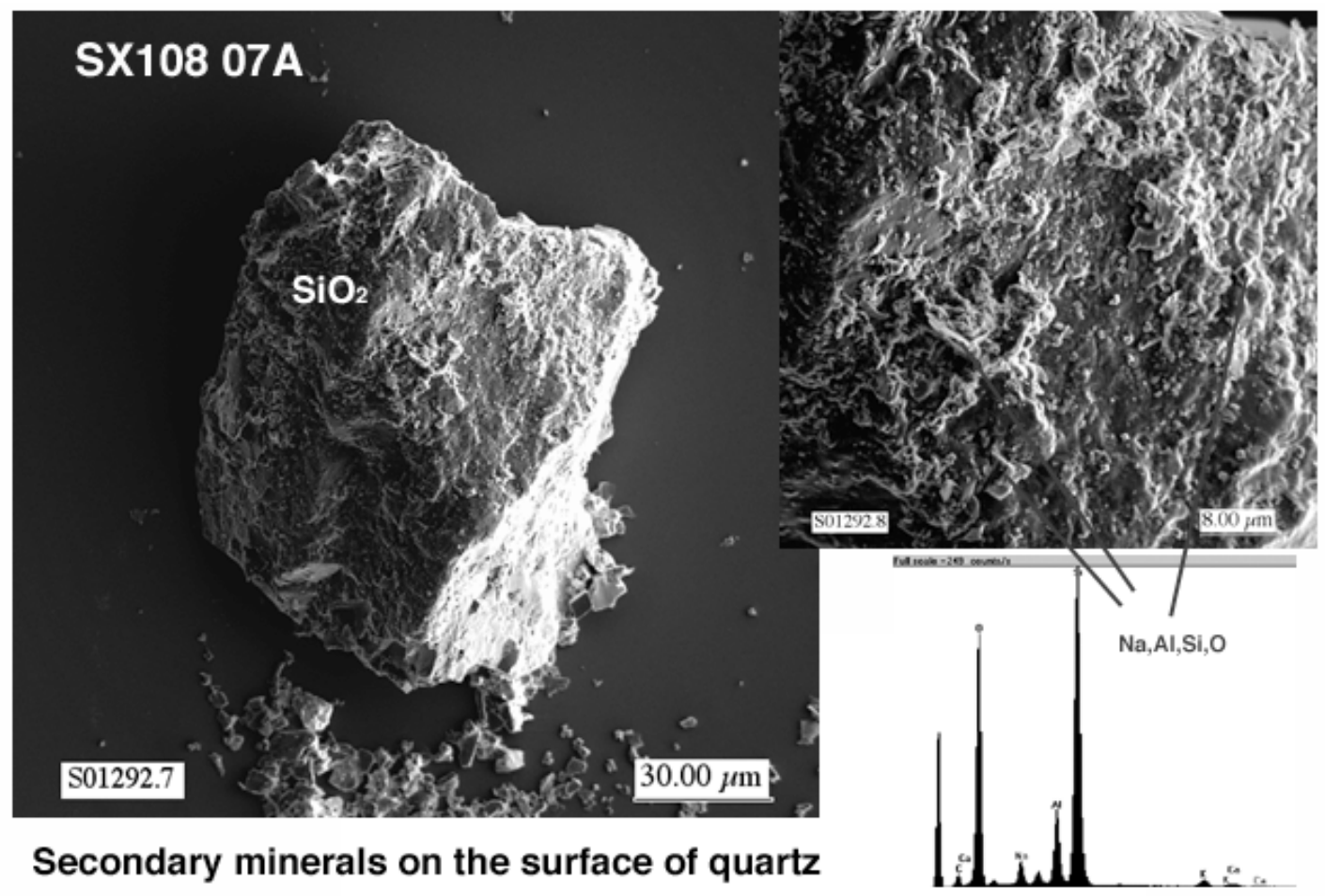

Figure 1. Secondary Zeolite on the Surface of a Quartz Grain from SX-108 Sample 07. The zeolite precipitate retains a small amount of ${ }^{137} \mathrm{Cs}$.

different compositions to study the rate and extent of ${ }^{137} \mathrm{Cs}$ desorption. These sediments have been contaminated for more than 20 years. Example results of these studies using $\mathrm{K}^{+}$electrolyte are shown in Figure 2. $\mathrm{Cs}^{+}$desorption occurs rapidly (within $10 \mathrm{~d}$ ) when the contaminated sediment is contacted with electrolyte. Additional ${ }^{137} \mathrm{Cs}$ is released when the ionic strength is increased by a factor of 20, indicating an ion exchange process. Generally, it was found that from $25-40 \%$ of the adsorbed ${ }^{137} \mathrm{Cs}$ was readily desorbed in electrolyte. Desorption studies performed with an acidic, $\mathrm{Fe}(\mathrm{III}) / \mathrm{Al}(\mathrm{III})$ complexing media showed enhanced release of ${ }^{137} \mathrm{Cs}$. These studies implied that secondary surface precipitates of $\mathrm{Al}$ and Fe oxides, resulting from waste sediment reaction, inhibit Cs exchangeability with the aqueous phase.

The multi-site model of Cs adsorption that we developed in our FY97 EMSP project provided excellent predictions of desorption extent after estimates were made of the exchangeable fraction. Our multi-site equilibrium model was linked with a diffusion model to simulate the time variant kinetics ${ }^{137} \mathrm{Cs}$ release from the contaminated sediments in different electrolytes. The model showed that desorption of the exchangeable ${ }^{137} \mathrm{Cs}$ pool can be quite rapid, if high electrolyte concentrations exist. 

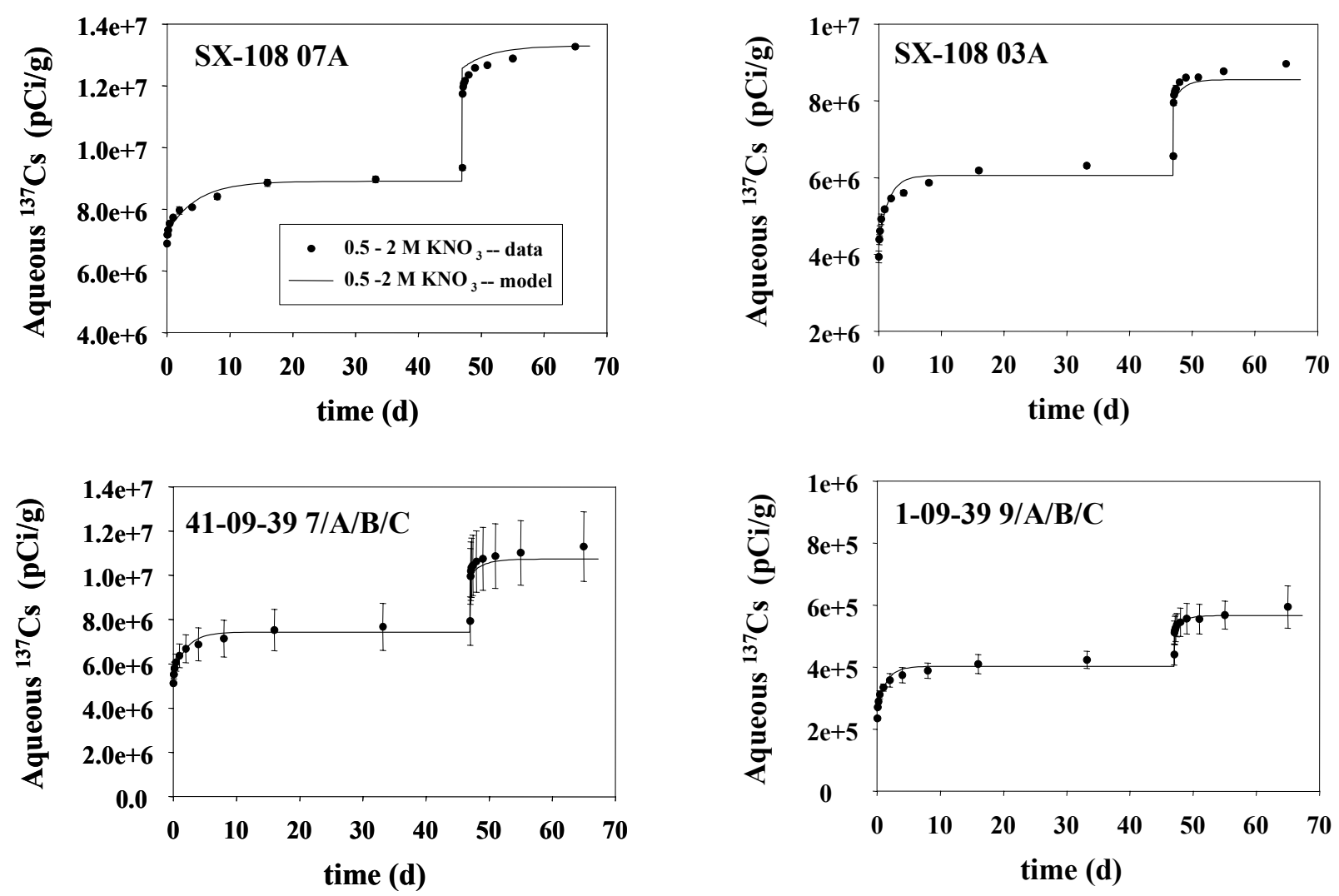

Figure 2. Aqueous Exchange Data and Results of Three-Site Model Simulations for $\mathrm{KNO}_{3}$ or $\mathrm{RbNO}_{3}$ Exchange at $0.1 \mathrm{M}$ (0 to 47 days) and $2.0 \mathrm{M}$ (47 to 64 days) with ${ }^{137} \mathrm{Cs}-\mathrm{Contaminated} \mathrm{Sediments}$

Three important implications of our project work are known to date:

- Approximately $25-40 \%$ of the in-ground, sorbed pool of ${ }^{137} \mathrm{Cs}$ is exchangeable in the S-SX tank farm and could be transported to groundwater if high electrolyte concentrations existed.

- Mobilization and further transport of ${ }^{137} \mathrm{Cs}$ is not expected, however, unless tank waste retrieval operations (for example, sluicing) release significant volumes of water with high $\mathrm{Na}$ concentrations $(>1.0 \mathrm{~mol} / \mathrm{L})$.

- Models developed by this project and its predecessor can be used to estimate the future transport behavior of ${ }^{137} \mathrm{Cs}$ in Hanford tank farms and to evaluate the effects of different leak-loss scenarios on ${ }^{137} \mathrm{Cs}$ mobilization and transport.

\section{Planned Activities}

We intend to study other ${ }^{137} \mathrm{Cs}$-contaminated materials from different Hanford tank farms over the next two years. These studies will allow us to develop a comprehensive understanding of the waste composition, geochemical, and mineral structural factors controlling the long-term 
behavior of ${ }^{137} \mathrm{Cs}$ in Hanford sediments. This information will be integrated into our kinetic desorption model that will be used to forecast future mobilization and transport of ${ }^{137} \mathrm{Cs}$ in response to various environmental management and waste retrieval scenarios.

\section{Information Access}

Zachara JM, SC Smith, C Liu, JP McKinley, RJ Serne, and PL Gassman. 2001. "Sorption of $\mathrm{Cs}+$ to micaceous subsurface sediments from the Hanford Site, USA." Geochimica et Cosmochimica Acta (In press).

McKinley JP, RJ Serne, JM Zachara, CJ Zeissler, and RM Lindstrom. 2001. "The distribution and retention of ${ }^{137} \mathrm{Cs}$ in sediments at the Hanford Site, Washington." Environmental Science and Technology (In press). 


\section{Technetium Attenuation in the Vadose Zone: Role of Mineral Interactions}

(Project Number: 70177)

\section{Principal Investigator}

Nancy J. Hess

Pacific Northwest National Laboratory

P.O. Box 999, MSIN P7-50

Richland WA 99352

(509) 376-9808 (phone)

nancy.hess@pnl.gov

\section{Co-Investigators}

Steven D. Conradson

Los Alamos National Laboratory

MST-11, MS D429

Los Alamos, NM 87545

(505) 667-9584 (phone)

conradson@lanl.gov

James P. McKinley

Pacific Northwest National Laboratory

P.O. Box 999, MSIN K6-81

Richland, WA 99352

(509) 375-6841

james.mckinley@pnl.gov

Kenneth M. Krupka

Pacific Northwest National Laboratory

P.O. Box 999, MSIN K6-81

Richland, WA 99352

(509) 376-4412 (phone)

ken.krupka@pnl.gov
Dhanpat Rai

Pacific Northwest National Laboratory

P.O. Box 999, MSIN P7-50

Richland, WA 99352

(509) 373-5988 (phone)

dhan.rai@pnl.gov

Raymond E. Wildung

Pacific Northwest National Laboratory

P.O. Box 999, MSIN P7-54

Richland, WA 99352

(509) 376-5680

r.wildung@pnl.gov 


\section{Research Objective}

In the subsurface environment, the pertechnetate ion, $\mathrm{Tc}^{\mathrm{VII}} \mathrm{O}_{4}^{-}$, forms only weak surface complexes with hydroxylated surface sites on clays and $\mathrm{Al}$ and $\mathrm{Fe}^{\mathrm{III}}$ oxides, and consequently, is weakly sorbed by most sediments and subsurface materials. Thus, adsorption of $\mathrm{Tc}^{\mathrm{VII}}$ onto these surfaces is not a viable mechanism for the attenuation of Tc in unsaturated subsurface environments or the vadose zone. Only the reduction of $\mathrm{Tc}^{\mathrm{VII}}$ to $\mathrm{Tc}^{\mathrm{IV}}$, which results in the precipitation of low-solubility solids, will result in retention of Tc in the vadose zone. Possible reduction mechanisms are 1) homogenous reduction, 2) microbial reduction, and 3 ) heterogeneous reduction on mineral surfaces. The redox conditions in the vadose zone in the western United States are likely too oxidizing for homogeneous reduction of $\mathrm{Tc}^{\mathrm{VII}}$ or to support a viable, widely distributed population of Fe-reducing organisms that can reduce Tc directly or indirectly. Thus, the purpose of this research is the investigation of heterogeneous reduction of $\mathrm{Tc}^{\mathrm{VII}}$ on $\mathrm{Fe}^{\mathrm{II}}$-containing mineral surfaces and the stability of the resulting precipitated Tc solids.

\section{Research Progress and Implications}

This report summarizes research accomplishments after 1.5 years of a 3-year project. Substantial progress has been made in three areas: solubility studies, characterization of $\mathrm{Tc}^{\mathrm{IV}}$ solids, and speciation of Tc-contaminated soils from the Hanford Site.

\section{Solubility of $\mathrm{TcO}_{2} \cdot n \mathrm{H}_{2} \mathrm{O}$}

Previous $\mathrm{TcO}_{2} \cdot n \mathrm{H}_{2} \mathrm{O}$ solubility studies have had great difficulty in maintaining reducing conditions, resulting in the oxidation of $\mathrm{Tc}^{\mathrm{IV}}$ species to $\mathrm{Tc}^{\mathrm{VII}}$ species. Because $\mathrm{Tc}{ }^{\mathrm{VII}}$ solubility is orders of magnitudes greater than $\mathrm{Tc}^{\mathrm{IV}}$, the measured $\mathrm{Tc}^{\mathrm{IV}}$ in solution in these studies was less than $1 \%$ of the total Tc concentration. Solvent extraction techniques can measure the proportion of $\mathrm{Tc}^{\mathrm{IV}}$ to total $\mathrm{Tc}$ in solution with an accuracy of approximately $5 \%$; therefore, the reported $\mathrm{Tc}^{\mathrm{IV}}$ concentrations are well below the error of the oxidation state measurement. Using $0.02 \mathrm{M}$ hydrazine as a holding reductant, we are able to maintain reducing conditions for up to 65 days under acidic conditions resulting in measured $\mathrm{Tc}^{\mathrm{IV}}$ to total $\mathrm{Tc}$ concentrations of greater than $70 \%$ for the data shown in Figure 1. These results give increased confidence in the solubility data and its use for determination of thermodynamic data. The slight increase in solubility under basic conditions (displayed in Figure 1) has significant implications for the very basic radioactive waste stored in double-shell tanks at Hanford. Conducting solubility studies under basic conditions and in the presence of complexing ligands will be the focus of upcoming work.

We conducted X-ray absorption spectroscopic (XAS) investigations on the solution phase at $\mathrm{pH}$ 0.9 and the $\mathrm{TcO}_{2} \cdot n \mathrm{H}_{2} \mathrm{O}$ solid phase at $\mathrm{pH} 4.1$ at the Stanford Synchrotron Radiation Laboratory. Analysis of the X-ray absorption near edge structure (XANES) revealed that the Tc oxidation state for both samples is $\mathrm{Tc}^{\mathrm{NV}}$, which is consistent with the solvent extraction results. In addition, analysis of the extended X-ray absorption fine structure (EXAFS) indicated that the first coordination sphere consists of oxygen atoms for both samples. Fits to the EXAFS of the solution sample at $\mathrm{pH} 0.9$ show that Tc is coordinated by six oxygen atoms at $2.19 \AA$. This result 


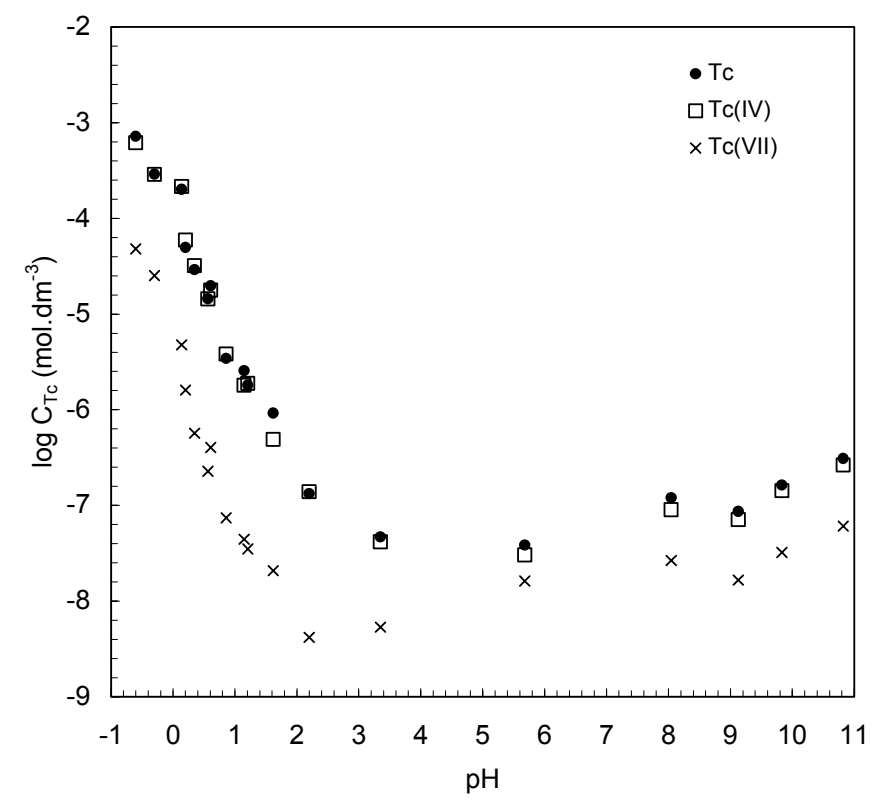

Figure 1. Solubility of $\mathrm{TcO}_{2} \cdot n \mathrm{H}_{2} \mathrm{O}$ as Function of $\mathrm{pH}$ after 11 Days' Equilibration in Presence of $0.02 \mathrm{M}$ Hydrazine to Maintain Reducing Conditions

is significant because definitive identification of the existence of a "bare" $\mathrm{Tc}^{4+}$ ion species at low $\mathrm{pH}$ is critical to correct thermodynamic modeling of the solubility data, especially in light of recent work by others suggesting the presence of mixed chloride species like $\mathrm{TcOCl}^{+}$under highly acidic conditions. Fits to the solid phase data at $\mathrm{pH} 4.1$ indicate the presence of two coordination shells: six oxygen atoms at $2.01 \AA$ and one Tc atom at $2.55 \AA$, which is consistent with previous results for the $\mathrm{TcO}_{2} \cdot n \mathrm{H}_{2} \mathrm{O}$ solid phase. Fourier transforms of the EXAFS are shown in Figure 2.

A review of previous $\mathrm{TcO}_{2} \cdot n \mathrm{H}_{2} \mathrm{O}$ solubility studies suggests that the measured solubility depended on the process used to generate the solid phase. Differences of an order of magnitude in Tc solubility have been observed when the solubility of electrochemically deposited $\mathrm{TcO}_{2} \cdot n \mathrm{H}_{2} \mathrm{O}$ was compared to chemical reduction of pertechnetate, yet both materials are $\mathrm{X}$-ray amorphous. We undertook a limited study of $\mathrm{TcO}_{2} \cdot n \mathrm{H}_{2} \mathrm{O}$ precipitates formed by chemical reduction using hydrazine, sodium dithionite, and microbial reduction using the dissimulatory iron-reducing bacteria Schewanella Putrifaciens and compared the diffuse X-ray scattering patterns and EXAFS. Although the samples are largely amorphous, diffraction peaks are clearly apparent in the pattern in Figure 3(a). These patterns have not been matched to any known Tc structure, and further analysis is in progress. Fourier transforms of the EXAFS of the samples are shown in Figure 3(b). Fits to the EXAFS indicate that variations in the amplitudes of the transform are due to variation in the disorder associated with each sample. Variation in disorder is also evident in minor transform peaks between 3 to $4 \AA$ apparent radial distance. Surprisingly, the microbially reduced $\mathrm{TcO}_{2} \cdot n \mathrm{H}_{2} \mathrm{O}$ appears to have the highest degree of order. Future work will entail a thorough analysis of the diffuse X-ray scattering data including calculation of the 


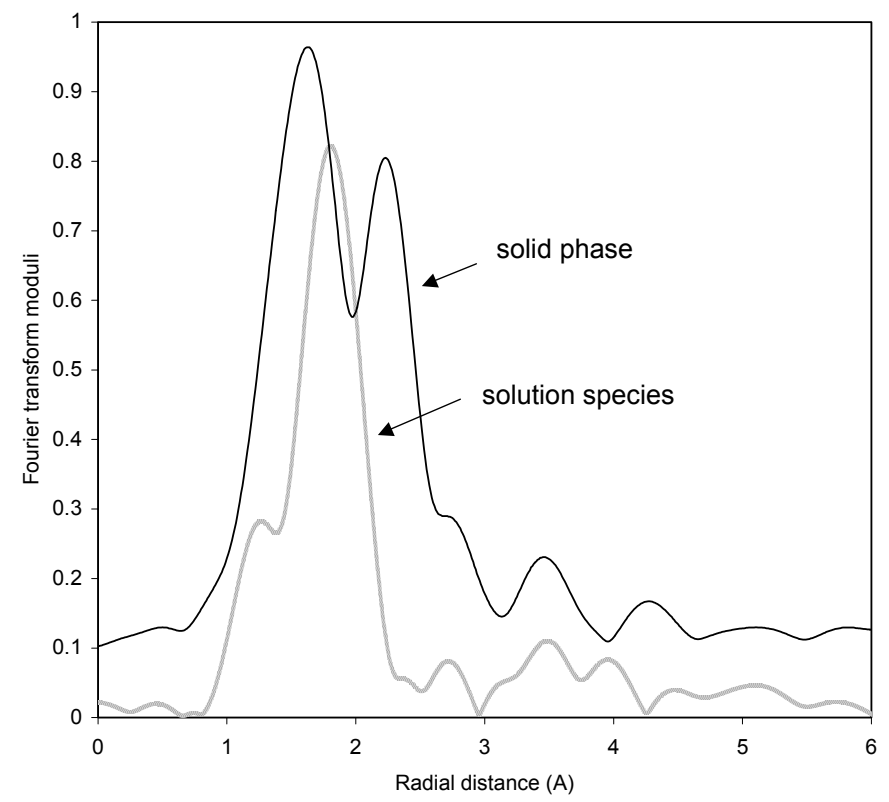

Figure 2. Fourier Transform of Tc K-Edge EXAFS for Solution and Solid Phase Samples
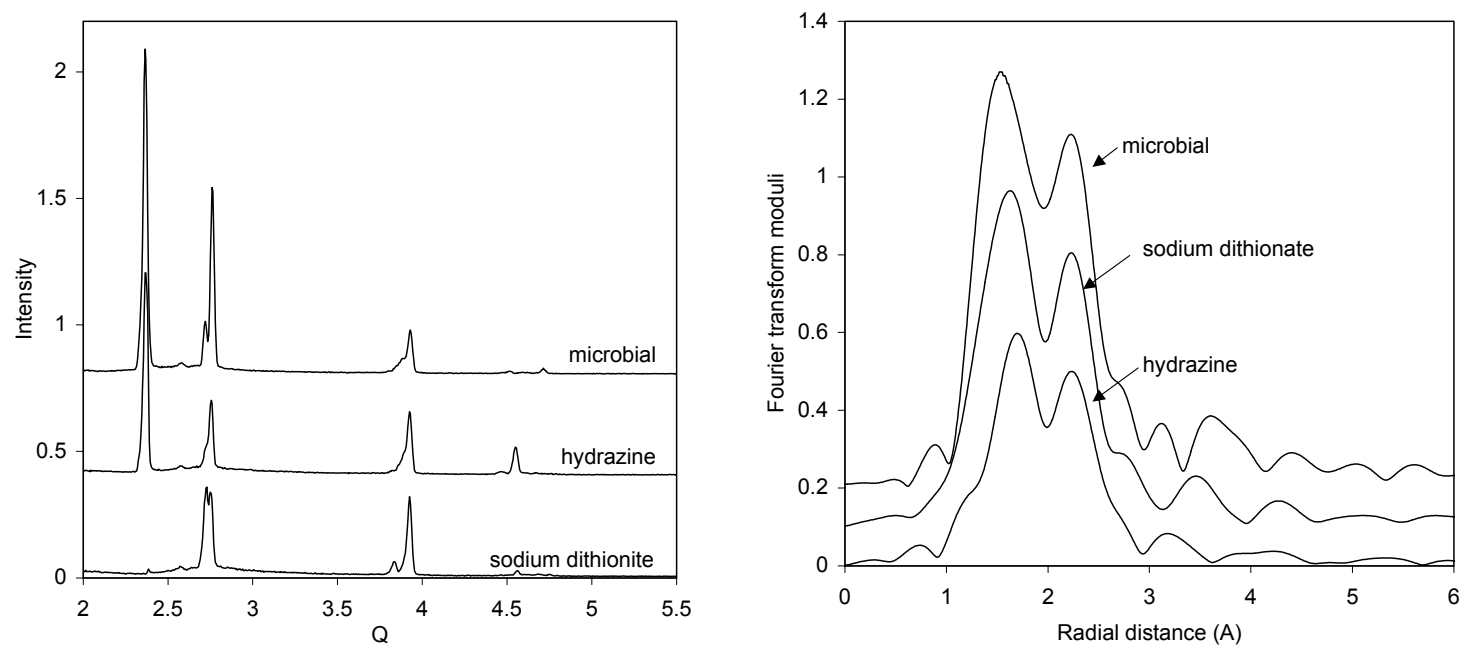

Figure 3. (a, left) A portion of the diffuse X-ray scattering pattern in Q-space showing diffraction peaks in the three $\mathrm{TcO}_{2} n \mathrm{H}_{2}$ ) "amorphous" precipitates using different reductants. (b, right) Fourier transform of the EXAFS of the same three samples. The transforms are offset vertically and have not been corrected for phase shift.

pair distribution function, identification of the crystalline component possibly using Reitveld analysis of the diffraction data, and solubility studies on each of the $\mathrm{TcO}_{2} \cdot n \mathrm{H}_{2} \mathrm{O}$ samples to determine whether the apparent variation in disorder is reflected in the measured solubility products. 


\section{Autoradiography of Tc-Contaminated Hanford Soils}

We obtained Tc-contaminated samples from a borehole in the 200 West Area of the Hanford Site for autoradiography experiments. Autoradiography relies on the decay of radionuclide to expose a film plate indicating the spatial location of the radionuclide, which then can be isolated for further analysis. Samples from six intervals from the 299-W23-19 borehole were selected for autoradiography experiments because the contamination is exclusively due to ${ }^{99} \mathrm{Tc}$, thus reducing the interference of other radionuclides such as ${ }^{137} \mathrm{Cs}$. Initial results indicate that Tc is not homogenously distributed but is associated with individual soil grains, as shown in Figure 4. The next step is to isolate and identify the soil grains with localized Tc concentrations using scanning electron microscopy. The association of Tc with a specific mineral grain may reveal the role of mineral interactions in the attenuation of Tc in the vadose zone.

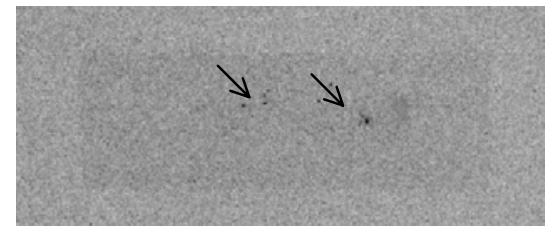

Figure 4. Autoradiography Image of

Sleeve 33G Showing Localized

Tc, Indicated by Arrow

\section{Planned Activities}

In addition to extending the work presented above, the following projects will be initiated:

\section{X-Ray Absorption Spectroscopy of Tc-Contaminated Soils}

The oxidation state of Tc is most likely the dominant factor in predicting the mobility of Tc in the vadose zone. We will conduct a thorough analysis of the XANES, the oxidation state of Tc-contaminated samples obtained from two boreholes in the 200 West Area of the Hanford Site, in June 2001. Both untreated samples and water-washed samples from the SX-slant borehole will be analyzed. It is anticipated that the untreated samples will contain all Tc species present, whereas the water-washing treatment is likely to remove highly soluble Tc(VII) species and leave insoluble reduced Tc species behind. The identification of reduced Tc species has significant implications for the mobility of Tc in the vadose zone.

\section{Heterogeneous Precipitation of Tc on Fe"-Containing Minerals}

We will determine the distribution, composition, and speciation of Tc precipitates or co-precipitates formed on Fe-oxide surfaces using high spatial resolution chemical imaging and spectroscopic techniques including autoradiography and scanning electron microscopy. Selected 
samples with Tc-precipitates will be sent to Stanford Synchrotron Radiation Laboratory or to the Advanced Photon Source for high spatial resolution XANES analysis using focused beam capabilities.

\section{Information Access}

1999-2000 Progress Report. http://www.osti.gov/em52/2000projsum/70177.pdf

Poster Board EMSP Workshop, April 2000.

http://www.osti.gov/em52/NWS2000_Posters/id70177.pdf 


\section{The Influence of Calcium Carbonate Grain Coatings on Contaminant Reactivity in Vadose Zone Sediments}

(Project Number: 70121)

\section{Principal Investigator}

John M. Zachara

Pacific Northwest National Laboratory

P.O. Box 999, MSIN K8-96

Richland, WA 99352

(509) 376-3254 (phone)

(509) 376-3650 (fax)

john.zachara@pnl.gov

\section{Co-Investigators}

Scott Chambers

Pacific Northwest National laboratory

P. O. Box 999, MISN K8-93

Richland, WA 99352

(509) 376-1766 (phone)

(509) 376-5106 (fax)

sa.chambers@pnl.gov

Gordon E. Brown, Jr.

Stanford University

Stanford, CA 94305

(650) 723-9168 (phone)

(650) 725-2199 (fax)

gordon@pangea.stanford.edu

Carrick M. Eggleston

University of Wyoming

P.O. Box 3006

Laramie, WY 82071

(307) 766-6769 (phone)

(307) 766-6679 (fax)

carrick@uwyo.edu 


\section{Research Objective}

Calcium carbonate $\left(\mathrm{CaCO}_{3}\right)$ is widely distributed through the Hanford vadose zone as a minor phase. As a result of current and past geochemical processes, $\mathrm{CaCO}_{3}$ exists as grain coatings, intergrain fill, and distinct caliche layers in select locations. Calcium carbonate may also precipitate when high-level wastes react with naturally $\mathrm{Ca}$ - and $\mathrm{Mg}$-saturated Hanford sediments. Calcium carbonate is a very reactive mineral phase. Sorption reactions on its surface may slow the migration of certain contaminants $(\mathrm{Co}, \mathrm{Sr})$, but its surface coatings on other mineral phases may diminish contaminant retardation (for example, $\mathrm{Cr}$ ) by blocking surface reaction sites of the substrate.

This project explores the behavior of calcium carbonate grain coatings, including how they form and dissolve, their reactivity toward key Hanford contaminants, their impact (as surface coatings) on the reactivity of other mineral substrates, and on their in-ground composition and minor element enrichment. The importance of $\mathrm{CaCO}_{3}$ as a contaminant sorbent will be defined in all of its different manifestations in Hanford sediments: dispersed minor lithic fragments, pedogenic carbonate coatings on gravel and stringers in silt, and nodules in clay and paleosols. Mass action models will be developed that allow understanding and prediction of the geochemical effects of $\mathrm{CaCO}_{3}$ on contaminant retardation in Hanford sediments.

\section{Research Progress and Implications}

This project is in its second year of performance. Research is under way at Pacific Northwest National Laboratory (reactivity of natural $\mathrm{CaCO}_{3}$ in Hanford sediments), Stanford University (influence of $\mathrm{CaCO}_{3}$ grain coatings on the reduction of $\mathrm{Cr}(\mathrm{VI})$ by magnetite and biotite), and the University of Wyoming (growth and dissolution processes of calcite and magnesite in presence of contaminants). Only the results of the Pacific Northwest National Laboratory research are described here.

A series (6) of $\mathrm{CaCO}_{3}$-containing sediments (2\% to 7\%) was obtained from subsurface cores collected in the S-SX (200 West) and B-BX-BY (200 East) tank farms at Hanford. Three of these sediments contained minor, detrital lithic fragments of $\mathrm{CaCO}_{3}$, and two others contained pedogenic calcite. One of the 200 West sediments was paleosol caliche (calcrete) from the pliopleistocene contact. Two other samples of bedded pedogenic caliche were also obtained from outcroppings on the Hanford Site.

The three caliche samples were thin-sectioned and analyzed by transmission electron microscopy and electron microprobe to determine the structure and minor element composition of the caliche. Results (exemplified in Figure 1) indicated the caliche exhibited complex structure and composition. The Sr and Si were common minor element impurities that seemed to be co-enriched along the most recent growth surfaces of the caliche. The native Sr concentrations were significant. All three caliche samples showed similar compositional patterns. The 


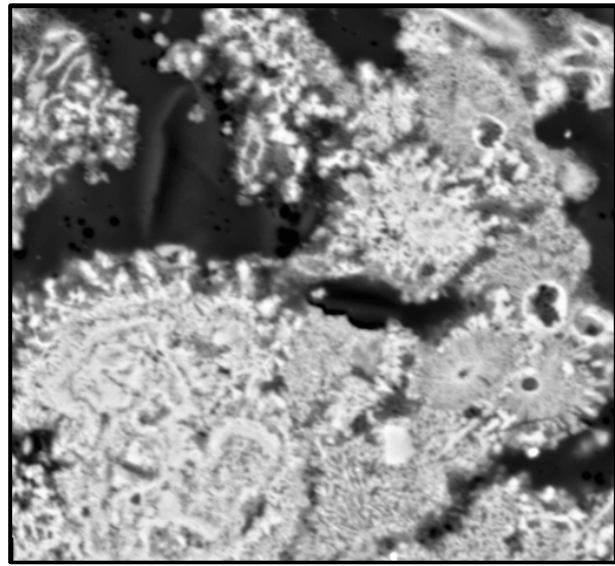

$10.0 \mu \mathrm{m}$

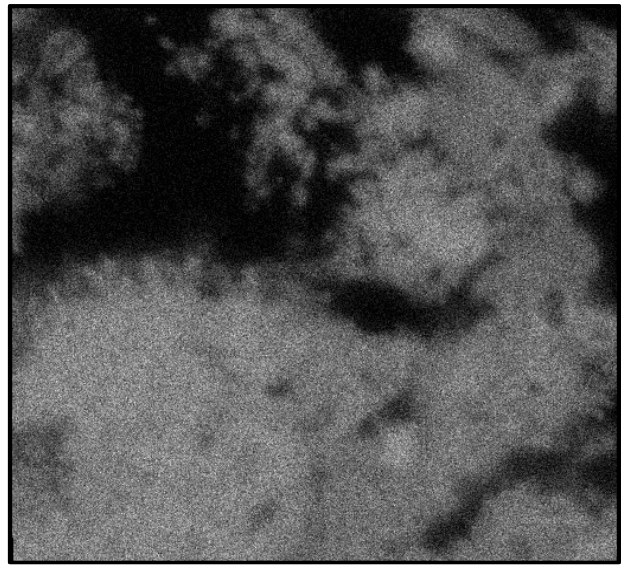

$10.0 \mu \mathrm{m}$

A $30-\mu \mathrm{m}$ thin section was analyzed by electron microprobe. The backscattered image (left) showed pore spaces (black) and porous radial $\mathrm{CaCO}_{3}$. The Ca elemental map (right) closely paralleled the backscattered image.

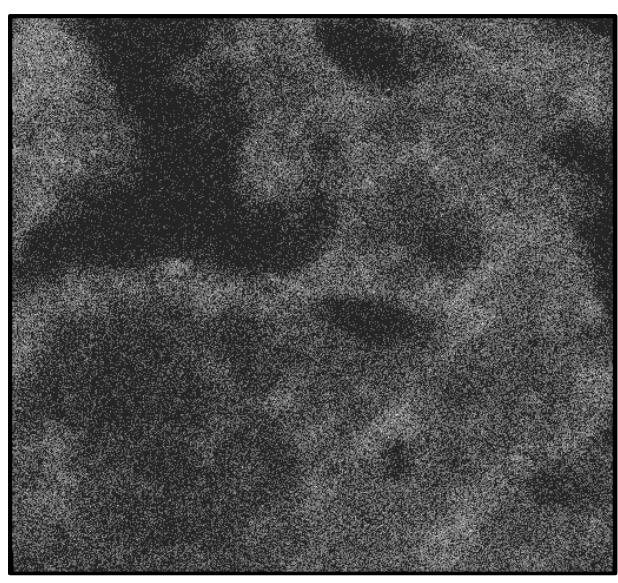

$10.0 \mu \mathrm{m}$

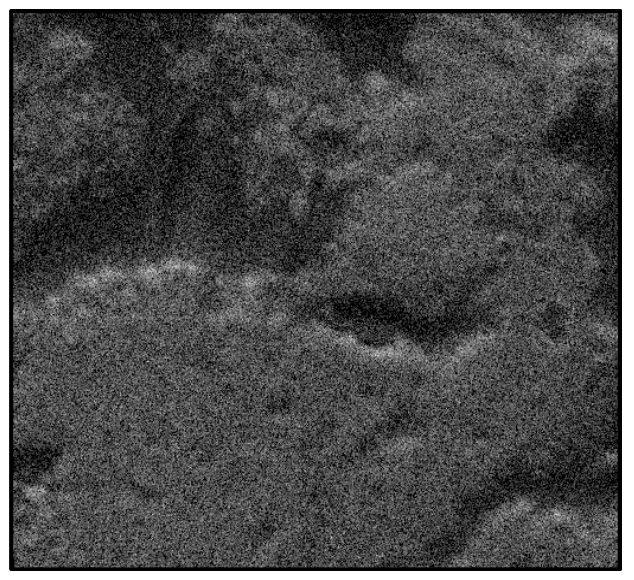

$10.0 \mu \mathrm{m}$

The $\mathrm{CaCO}_{3}$ contained $\mathrm{Si}$, with accumulation in porous surface regions (left). $\mathrm{Sr}$ (right) also concentrated in Si-rich, porous regions.

Figure 1. Electron Microprobe Analysis of Caliche 
hypothesis underlying this project is that most contaminant sorption to caliche will occur in regions of $\mathrm{Si}$ enrichment, and that ${ }^{90} \mathrm{Sr}$ will be preferentially adsorbed to areas of $\mathrm{Sr}$ accumulation by isotopic exchange.

Four of the sediments with different $\mathrm{CaCO}_{3(\mathrm{~s})}$ contents were equilibrated in $\mathrm{CaCO}_{3(\mathrm{aq})}$ solutions that differed in $\mathrm{pH}$ (7.2 to 9.8) and Ca concentration $\left(10^{-3.7}\right.$ to $\left.10^{-1.7} \mathrm{~mol} / \mathrm{L}\right)$. All of the $\mathrm{CaCO}_{3(\mathrm{aq})}$ solutions had been pre-equilibrated with $\mathrm{CaCO}_{3(\mathrm{~s})}$. The total normality of all the solutions was adjusted using $\mathrm{NaHCO}_{3}, \mathrm{NaClO}_{4}$, and/or $\mathrm{NaOH}$. The ion composition of the solutions took an additional 2 weeks to stabilize with respect to $\mathrm{Mg}^{2+}, \mathrm{Sr}^{2+}$, and $\mathrm{Si}(\mathrm{OH})_{4}^{-}$. The aqueous concentrations of $\mathrm{Sr}^{2+}$ arising from dissolution from the sediment ranged from $10^{-5}$ to $10^{-6} \mathrm{~mol} / \mathrm{L}$. Following stabilization, the suspensions were spiked with ${ }^{90} \mathrm{Sr}\left(10^{-8} \mathrm{~mol} / \mathrm{L}\right)$, and its distribution followed with time. The adsorption of ${ }^{90} \mathrm{Sr}$ occurred rapidly without significant kinetic behavior. The distribution coefficient $\left[\mathrm{K}_{\mathrm{d}}=(\mathrm{mol} / \mathrm{g}\right.$-sorbed $) /(\mathrm{mol} / \mathrm{L}$-solution $)$; a measure of sorption strength] varied by two orders of magnitude (Figure 2 ), depending on aqueous $\mathrm{Ca}^{2+}$ concentration.

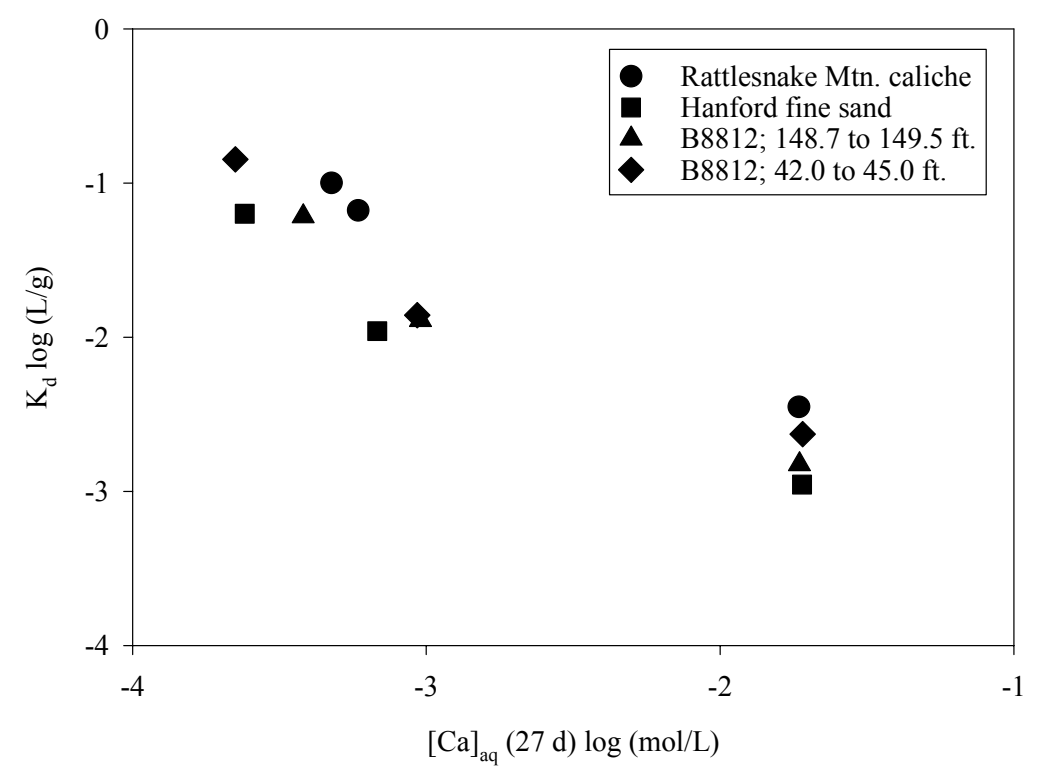

Figure 2. Distribution Coefficient $\left(\mathrm{K}_{\mathrm{d}}\right)$ of $\mathrm{Sr}^{2+}$ with Selected Caliche-Bearing Materials

To date, our results indicate that ${ }^{90} \mathrm{Sr}$ is retained by Hanford sediment by a complex isotopic exchange process. The ${ }^{90} \mathrm{Sr}$ exchanges with the native ${ }^{86 / 88} \mathrm{Sr}$ pool, and the extent of sorption is dependent on the surface concentration of ${ }^{86 / 88} \mathrm{Sr}$ and the mineral phases with which it is associated. Calcium plays a major role in controlling the distribution of the native Sr through ion exchange and surface exchange processes on layer silicates and $\mathrm{CaCO}_{3(\mathrm{~s})}$. 


\section{Planned Activities}

- Phosphor imaging study of locations of ${ }^{90} \mathrm{Sr}$ adsorption in caliche to the resolution scale of $25 \mu \mathrm{m}$. Does ${ }^{90} \mathrm{Sr}$ accumulate with native $\mathrm{Sr}$ in different types of caliche from Hanford?

- Ion exchange isotherms of $\mathrm{Sr}^{2+}$ in $\mathrm{Na}^{+}$and $\mathrm{Ca}^{2+}$ electrolytes to define factors/reactions controlling the surface excess of native $\mathrm{Sr}^{2+}$ in Hanford sediments. Is the ion exchange behavior of $\mathrm{Sr}^{2+}$ affected by the presence of $\mathrm{CaCO}_{3(\mathrm{~s})}$ ?

- Kinetic isotopic exchange studies of ${ }^{90} \mathrm{Sr}$ in Hanford sediments with different concentrations and mineral distributions of native Sr. Is the adsorption process of ${ }^{90} \mathrm{Sr}$ driven by isotopic exchange to carbonates or layer silicates?

- Development of a reaction-based isotopic exchange model for ${ }^{90} \mathrm{Sr}$ adsorption to Hanford sediment.

\section{Information Access}

Zachara JM, SC Smith, JP McKinley, and C Liu. 2001. "Sorption of ${ }^{90} \mathrm{Sr}$ in Calcareous Hanford

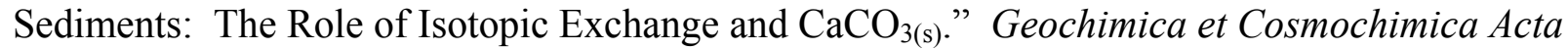
(Submitted). 


\section{The Aqueous Thermodynamics and Complexation Reactions of Anionic Silica Species to High Concentration: Effects on Neutralization of Leaked Tank Wastes and Migration of Radionuclides in the Subsurface}

(Project Number: 70163)

\section{Principal Investigator}

Andrew R. Felmy

Pacific Northwest National Laboratory

P.O. Box 999, MSIN K8-96

Richland, WA 99352

(509) 376-4079 (phone)

(509) 376-3650 (fax)

ar.felmy@pnl.gov

\section{Co-Investigators}

Gregory Choppin

The Florida State University

Department of Chemistry, B-164

Tallahassee, FL 32606-3006

(904) 644-3875 (phone)

(904) 644-8281 (fax)

Choppin@chemmail.chem.fsu.edu

David A. Dixon

Pacific Northwest National Laboratory

P.O. Box 999, MSIN K1-83

Richland, WA 99352

(509) 372-4999 (phone)

(509) 375-6631 (fax)

da.dixon@pnl.gov 


\section{Problem Statement and Research Objective}

Highly basic tank wastes contain several important radionuclides, including ${ }^{90} \mathrm{Sr},{ }^{99} \mathrm{Tc}$, and ${ }^{60} \mathrm{Co}$, as well as actinide elements (i.e., isotopes of $\mathrm{U}, \mathrm{Pu}$, and $\mathrm{Am}$ ). These highly basic tank wastes are known to have leaked into the vadose zone at the Hanford Site. Upon entering the sediments in the vadose zone, the highly basic solutions dissolve large concentrations of silica from the silica and aluminosilicate minerals present in the subsurface. These dissolution reactions alter the chemical composition of the leaking solutions, transforming them from a highly basic (as high $2 \mathrm{M} \mathrm{NaOH}$ ) solution into a pore solution with a very high concentration of dissolved silica and a significantly reduced $\mathrm{pH}$. This moderately basic ( $\mathrm{pH} 9$ to 11), high-silica solution has the potential to complex radionuclides and move through the subsurface. Such strong radionuclide complexation is a currently unconsidered transport vector that has the potential to expedite radionuclide transport through the vadose zone. These strong complexation effects have the ability to significantly alter current conceptual models of contaminant migration beneath leaking tanks.

In this project, we are determining the aqueous thermodynamics and speciation of dissolved silica and silica-radionuclide complexes to high silica concentration using a combination of

1. studies of chemical species structure and composition (via nuclear magnetic resonance and, where applicable, laser-induced fluorescence spectroscopy and x-ray absorption spectroscopy)

2. molecular simulations to help identify key species structures and assist in interpreting experimental measurements

3. fundamental physical chemistry measurements, including solubility, electromotive force, and isopiestic measurements, to obtain the necessary thermodynamic data for predicting contaminant complexation and waste neutralization reactions.

The radioactive elements we plan to study include Sr, Co, Cs, Am(III), and U(VI).

\section{Research Progress and Implications}

We have focused our FY01 efforts on 1) developing a chemical model to predict the speciation reactions of the monomeric and polymeric silica species under high base and high silica concentration and 2) the complexation reactions of these silica species with $\mathrm{Sr}, \mathrm{U}$, and $\mathrm{Cm}$. This task is quite daunting because of the number of silica species simultaneously present in solution (i.e., monomers, dimers, trimers, tetramers, and hexamers) all of which have different protonation states and different association reactions with bulk cations and anions. 


\section{Studies of Silica Speciation}

In FY01, an aqueous thermodynamic model for polymerized silica species that is valid to high ionic strengths and high dissolved silica concentration $(\sim 0.1 \mathrm{~m})$ at low temperature $\left(22-25^{\circ} \mathrm{C}\right)$ was completed. The model is based on the equations of Pitzer and has been parameterized from solubility, electromotive force, and nuclear magnetic resonance data. The description of the silica speciation reactions at high dissolved silica and basic conditions $(\mathrm{pH}>10)$ required the inclusion of monomeric, dimeric, trimeric (linear, cyclic, and substituted), tetrameric (linear and cyclic) and hexameric (prismatic) species. The standard state equilibrium constants (Table 1) for the formation of these species, as well as the necessary Pitzer ion-interaction parameters to describe the ionic strength dependence of the formation reactions were determined.

Interestingly, the formation constants for species with the same number of silicas (i.e., the trimers and the tetramers) show very similar formation constants. This fact is completely consistent with the nuclear magnetic resonance measurements and is supported also by the molecular dynamics calculations, which show that in $\mathrm{Na}^{+}$containing solutions the "linear" and "cyclic" silica species are predicted to have similar structures (Figure 1). The $\mathrm{Na}^{+}$cation alters the "linear" trimers and tetramers in solution forming a type of bridge linking the oxygens at the ends of the "linear" silica species. The predicted solution phase structures for these "linear" and "cyclic" species in $\mathrm{Na}^{+}$containing solutions are remarkably similar, which leads to the similar stability constants.

Table 1. Aqueous Species and Equilibrium Constants Used in This Study

\begin{tabular}{||l|l|c||}
\hline \hline $\mathrm{p}, \mathrm{q}$ & \multicolumn{1}{|c|}{ Formula } & Log $\mathrm{K}^{0}$ (final) \\
\hline \hline$-1,1$ & $\mathrm{H}_{3} \mathrm{SiO}_{4}{ }^{-}$ & -9.82 \\
\hline$-2,1$ & $\mathrm{H}_{2} \mathrm{SiO}_{4}{ }^{2-}$ & -23.27 \\
\hline$-1,2$ & $\mathrm{Si}_{2} \mathrm{O}_{2}(\mathrm{OH})_{5}{ }^{-}$ & -8.50 \\
\hline$-2,2$ & $\mathrm{Si}_{2} \mathrm{O}_{3}(\mathrm{OH})_{4}{ }^{2-}$ & -19.4 \\
\hline$-3,3$ & $\mathrm{Si}_{3} \mathrm{O}_{6}(\mathrm{OH})_{3}{ }^{3-}(\mathrm{cyclo})$ & -29.3 \\
\hline$-3,3$ & $\mathrm{Si}_{3} \mathrm{O}_{5}(\mathrm{OH})_{5}{ }^{3-}(\mathrm{lin})$ & -29.4 \\
\hline$-4,4$ & $\mathrm{Si}_{4} \mathrm{O}_{7}(\mathrm{OH})_{6}{ }^{4-}(\mathrm{lin})$ & -39.1 \\
\hline$-4,4$ & $\mathrm{Si}_{4} \mathrm{O}_{8}(\mathrm{OH})_{4}{ }^{4-}(\mathrm{cyclo})$ & -39.2 \\
\hline$-4,4$ & $\mathrm{Si}_{4} \mathrm{O}_{8}(\mathrm{OH})_{4}{ }^{4-}(\mathrm{sub})$ & -39.1 \\
\hline$-2,4$ & $\mathrm{Si}_{4} \mathrm{O}_{6}(\mathrm{OH})_{6}{ }^{2-}$ & -15.6 \\
\hline$-6,6$ & $\mathrm{Si}_{6} \mathrm{O}_{15}{ }^{6-}$ & -57.9 \\
\hline
\end{tabular}


(a)

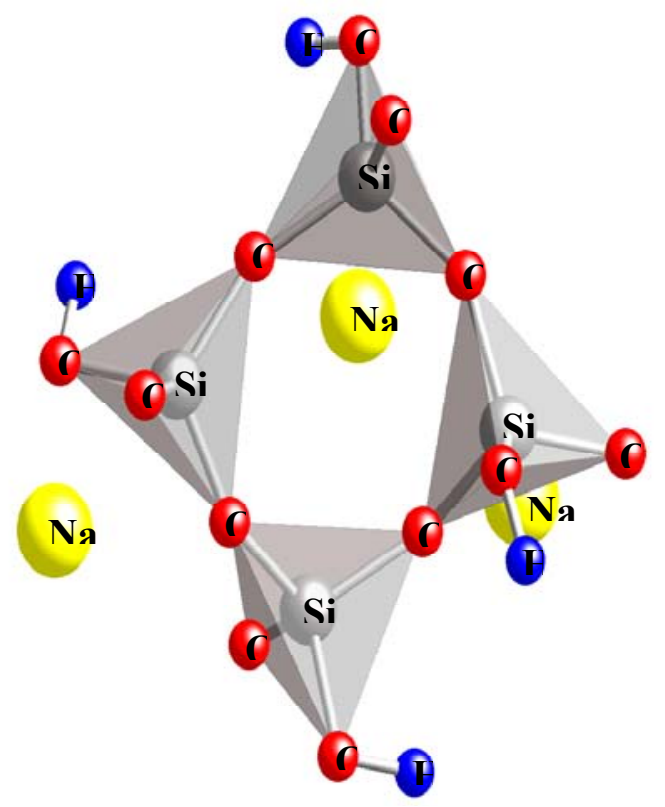

(b)

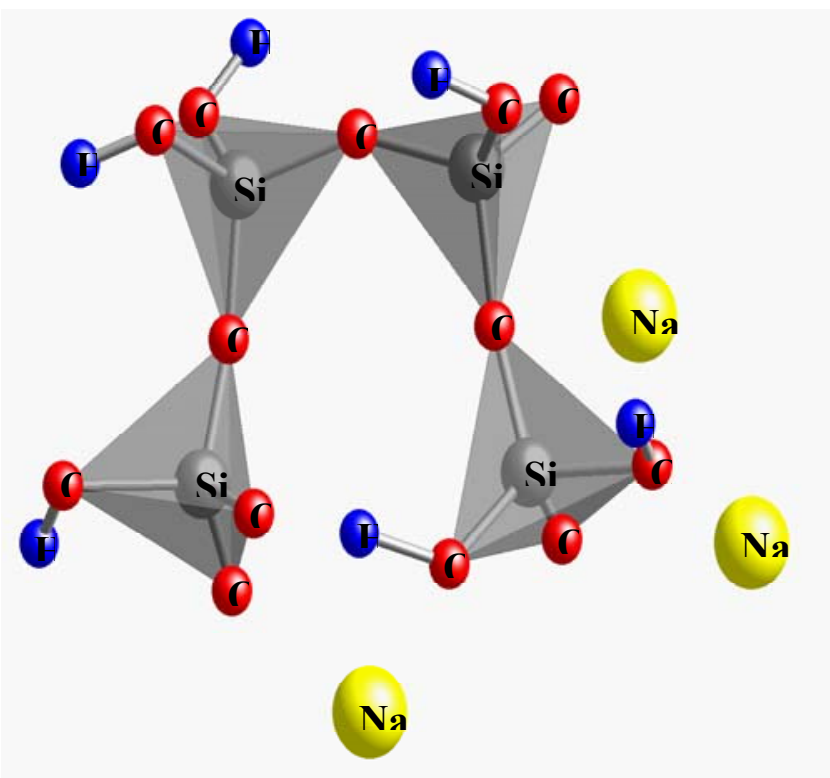

Figure 1. (a) Cyclic tetramer and (b) linear tetramer, both with associated sodium ions. Red atoms are oxygen, blue atoms are protons, gray atoms/polyhedra are silicon, and yellow atoms are sodium. Each species has a representative charge of $-4 e$ (sodium ions excluded). Strong intramolecular hydrogen bonding present in the linear trimer closes the gyration radius, giving rise to similar structures for the cyclic and linear tetramers. 


\section{Silica Complexation Reactions}

With an accurate thermodynamic model available to predict the complex solution speciation of silica, studies also were initiated on the complexation reactions of these silica species with the radionuclides. These initial studies focused on the reactions of the radionuclides with the monomeric silica species.

The interactions of $\mathrm{UO}_{2}{ }^{2+}, \mathrm{Eu}^{3+}, \mathrm{Am}^{3+}, \mathrm{Co}^{2+}$, and $\mathrm{Ni}^{2+}$ with monosilicic acid were investigated by a solvent extraction method. Under the experimental conditions used, the complexation reactions in aqueous phase between the radioactive elements $\left(\mathrm{M}^{\mathrm{n}+}\right)$ and the anion of orthosilicic acid $\left(\mathrm{L}^{+}\right)$can be written as

$$
\mathrm{M}^{\mathrm{n}+}+\mathrm{mL}^{-}=\mathrm{ML}_{\mathrm{m}}{ }^{(\mathrm{n}-\mathrm{m})^{+}}
$$

The distribution coefficient of the metal ions between the organic and aqueous phases in the presence of the ligand is

$$
1 / \mathrm{D}=1 / \mathrm{D}_{\mathrm{o}}\left(1+\beta_{1}\left[\mathrm{~L}^{-}\right]+\beta_{2}\left[\mathrm{~L}^{-}\right]^{2}+\ldots . .\right)
$$

where $\mathrm{D}_{\mathrm{o}}$ is the distribution coefficient measured in the absence of the ligand, and $\mathrm{L}^{-}$is the free ligand concentration calculated from the total ligand concentration and the measured $\mathrm{pH}$ after reaching extraction equilibrium. Free ligand concentration was calculated according to

$$
\left.\left[\mathrm{OSi}(\mathrm{OH})_{3}^{+}\right]=\left[\mathrm{Si}(\mathrm{OH})_{4}\right]_{\text {total }} 10^{(\mathrm{pH}-\mathrm{pK}} \mathrm{a}_{\mathrm{a}}\right)
$$

The $\mathrm{pK}_{\mathrm{a}}=9.55$ was extrapolated from a published value for $\mathrm{I}-0.2 \mathrm{M}(\mathrm{Na}, \mathrm{H}) \mathrm{ClO}_{4}$. In experiments with nickel $(\mathrm{pH}=5.5)$, it has been shown that polymerization of the ligand does not affect the dissolved metal concentration (there is no sorption of metal cation on condensation product of silicic acid).

The first stability constants of the 1:1 (M:L-) complexation have been measured to be $(\mathrm{I}=0.2 \mathrm{M}$ $\left.(\mathrm{Na}, \mathrm{H}) \mathrm{ClO}_{4}, \mathrm{~T}=25^{\circ} \mathrm{C}\right)$. The experimental stability constants are summarized below.

$$
\begin{array}{ll}
\mathrm{M}^{\mathrm{n}+} & \log \beta_{1} \\
\mathrm{Co}^{2+} & 4.8 \pm 0.5 \\
\mathrm{Ni}^{2+} & 5.3 \pm 0.5 \\
\mathrm{Eu}^{3+} & 7.04 \pm 0.10 \\
\mathrm{Am}^{3+} & 7.43 \pm 0.41 \\
\mathrm{UO}_{2}{ }^{2+} & 6.72 \pm 0.51
\end{array}
$$

In addition to the results for the monomeric silica complexes, studies of the interactions of the polysilicate species with the radionuclides also were initiated. These studies began with Sr. The initial results show that the presence of high concentrations of dissolved silica in solution results in the precipitation of a partially amorphous solid phase with a structure similar to tobermorite (a 
Ca silicate $\left.\left[\mathrm{Ca}_{5}\left(\mathrm{Si}_{6} \mathrm{O} 18 \mathrm{H}_{2}\right) \cdot 8 \mathrm{H}_{2} \mathrm{O}\right]\right)$. SEM images of the precipitate show the "sheaf of wheat" structure previously identified as a growth center for Type II calcium silicate hydrate (CSH) (Figure 2). Such structures have not been identified previously for Sr compounds. The strontium silicate hydrate ( $\mathrm{SSH}$ ) also had not been previously identified, but it appears to control the dissolved $\mathrm{Sr}$ and silicate concentrations in our low temperature $\left(22-23^{\circ} \mathrm{C}\right)$ solubility studies.

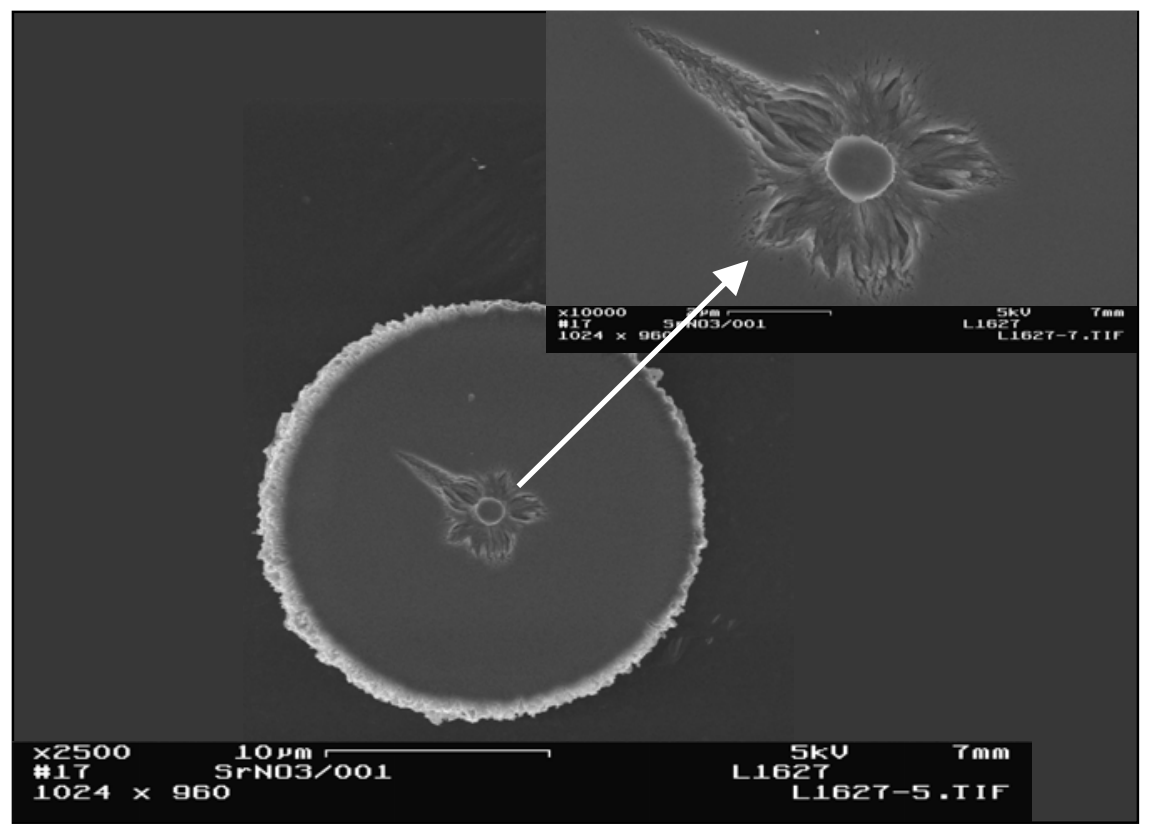

Figure 2. SEM Image of the Strontium Silicate Hydrate Particle Morphology Exhibiting the "sheaf of wheat" Nucleation Structure

\section{Hanford Site Coordination}

In addition to the scientific contributions described above, the project PIs also have participated in two vadose zone PI workshops to discuss the application of our results to on-going Hanford Site assessments. In addition, A.R. Felmy has been preparing a thermodynamic database that we will use for modeling the high ionic strength solutions that have been leaking from waste storage tanks. This database is being used by the Hanford Science and Technology Modeling team (led by S.B. Yabusaki of Pacific Northwest National Laboratory) to assess the impact on the subsurface of the leaking tank wastes. Much of this effort was supported by this EMSP project.

\section{Planned Activities}

In FY02, we plan to complete our studies of Sr silicate solid phases and polymeric silica complexation, and initiate studies on the polysilicate complexation of Cs, Cm, U(VI), and Co. Cs is being investigated since preliminary data on polysilicate solutions with added Cs show new peaks in the ${ }^{29} \mathrm{Si}$ NMR spectrum, which indicate the formation of a soluble Cs-polysilicate 
species. Such a species could be important in Cs transport, and it could provide fundamental data on the nature of Cs-silicate association that might help in unraveling the binding mechanism for Cs and clay mineral surfaces.

\section{Publications and Presentations}

Felmy AR, DA Dixon, and GR Choppin. 1999. "The Aqueous Thermodynamics and Complexation Reactions of Anionic Silica Species to High Concentration.” EMSP Principal Investigators Orientation Meeting, November 16, 1999, Richland, Washington.

Felmy AR, H Cho, JR Rustad, and MJ Mason. 2001. "An Aqueous Thermodynamic Model for Polymerized Silica Species to High Ionic Strength.” J. Solution Chem. 30(6), 1-17.

Felmy AR, H Cho, JR Rustad, DA Dixon, and GR Choppin. 2000. "The Aqueous Complexation Reactions of Anionic Silica Species to High Concentration." EMSP Vadose Zone Principal Investigators Workshop, November 28, 2000, Richland Washington.

Felmy AR, H Cho, GR Choppin, DA Dixon, GT MacLean, JR Rustad, Z Wang, and Y Xia. 2001. "Development of Accurate Chemical Models for Tank Waste Applications." Tanks Focus Area Mid-Year Review, March 12-15, 2001, Salt Lake City, Utah.

Felmy AR, GT Maclean, and S Sanders. 2001. "The Addition of Pitzer's Equations to ESP." Article in CHG Hanford Site News, May 2001.

AR Felmy and K Nagy are organizing the Accomplishments of the Environmental Management Sciences Program at the ACS National Meeting in Chicago, Illinois, August 26-31, 2001. Six sessions are planned. 


\section{Interfacial Reduction-Oxidation Mechanisms Governing Fate and Transport of Contaminants in the Vadose Zone}

(Project Number: 70088)

\section{Principal Investigator}

B. Deng

New Mexico Institute of Mining and Technology

(505) 835-5505 (phone)

bdeng@nmt.edu

\section{Co-Investigators}

Edward C. Thornton

Pacific Northwest National Laboratory

P.O. Box 999, MSIN K6-96

Richland, WA 99352

(509) 373-0358 (phone)

(509) 372-1704 (fax)

ec_thornton@pnl.gov

Kirk J. Cantrell

Pacific Northwest National Laboratory

P.O. Box 999, MSIN K6-81

Richland, WA 99352

(509) 376-2136 (phone)

(509) 376-5368 (fax)
Khris B. Olsen

Pacific Northwest National Laboratory P.O. Box 999, MSIN K6-96

Richland, WA 99352

(509) 376-4114 (phone)

(509) 372-1704 (fax)

James E. Amonette

Pacific Northwest National Laboratory P.O. Box 999, MSIN K8-96

Richland, WA 99352

(509) 376-5565 (phone)

(509) 376-3650 (fax)

\section{Other Contributors}

C. S. Kim

Y. Lan 


\section{Research Objective}

Immobilization of toxic and radioactive metals (e.g., $\mathrm{Cr}, \mathrm{Tc}$, and $\mathrm{U}$ ) in the vadose zone by in situ gaseous reduction using hydrogen sulfide $\left(\mathrm{H}_{2} \mathrm{~S}\right)$ is a promising technology the U.S. Department of Energy (DOE) is developing for soil remediation. Earlier laboratory studies have shown that $\mathrm{Cr}(\mathrm{VI})$ in a number of soil samples can be effectively immobilized by treatment with dilute gaseous $\mathrm{H}_{2} \mathrm{~S}$. A field test has also been completed that resulted in $70 \%$ immobilization of $\mathrm{Cr}(\mathrm{VI})$.

The objective of this project is to characterize the interactions among $\mathrm{H}_{2} \mathrm{~S}$, the metal contaminants, and soil components. Understanding these interactions is needed to assess the long-term effectiveness of the technology and to optimize the remediation system.

\section{Research Progress and Implications}

This report summarizes the research completed within the first 1.5 years of a 3 -year project.

\section{Evaluation of Potential Catalytic Effect of Mineral Surfaces on Rate of $\mathrm{Cr}(\mathrm{VI})$ Reduction by $\mathrm{H}_{2} \mathrm{~S}$ and Rate of $\mathrm{H}_{2} \mathrm{~S}$ Oxidation by Air}

Pacific Northwest National Laboratory has conducted a number of column experiments that involve treatment of $\mathrm{Cr}(\mathrm{VI})$-contaminated soil samples with diluted $\mathrm{H}_{2} \mathrm{~S}$. This includes tests conducted with a non-contaminated (background) soil sample from a waste site at White Sands Missile Range, New Mexico, where the first in situ gaseous reduction field test was conducted, and tests involving Hanford formation sand samples from the Hanford Site. The soil was treated with $\mathrm{H}_{2} \mathrm{~S} / \mathrm{N}_{2}$ or $\mathrm{H}_{2} \mathrm{~S} /$ air mixtures in two column tests, $\mathrm{H}_{2} \mathrm{~S}$ breakthrough data were collected, and the treated sediment was characterized. We used the results of these tests to develop a preliminary reactive transport model describing the interaction of $\mathrm{H}_{2} \mathrm{~S}, \mathrm{O}_{2}$, and the soil matrix. In particular, it appears that the soil iron oxides act as catalysts in the reaction between $\mathrm{H}_{2} \mathrm{~S}$ and oxygen in the $\mathrm{H}_{2} \mathrm{~S} /$ air test. Elemental sulfur was also identified as the predominant product of $\mathrm{H}_{2} \mathrm{~S}$ consumed during gas/soil interaction. Work to date on Hanford soil samples indicates that reduction of $\mathrm{Cr}(\mathrm{VI})$ to $\mathrm{Cr}(\mathrm{III})$ is essentially quantitative. A long-term oxidation test (over 1 year in duration) is also being performed on $\mathrm{H}_{2} \mathrm{~S}$-treated soil samples to verify that the reduced chromium will not be reoxidized.

\section{Identification of Reactions of Soil Minerals with $\mathrm{H}_{2} \mathrm{~S}$ and Determination of Associated Reaction Rates}

We have conducted additional testing in FY 2001 with iron oxides and clay minerals to develop a better understanding of the specific reactions involving soil components with $\mathrm{H}_{2} \mathrm{~S}$ gas mixtures and their associated rates. In particular, we recently completed experiments involving treatment of iron oxide-coated sand at three different flow rates with $\mathrm{H}_{2} \mathrm{~S} / \mathrm{N}_{2}$, one flow rate with $\mathrm{H}_{2} \mathrm{~S} /$ air, and one flow rate with $\mathrm{H}_{2} \mathrm{~S} / \mathrm{O}_{2}$. Results obtained in these tests suggest that competition exists between $\mathrm{H}_{2} \mathrm{~S}$ and $\mathrm{O}_{2}$ for adsorption sites on iron oxide phases; this effect results in a shorter 
breakthrough time for $\mathrm{H}_{2} \mathrm{~S}$ as $\mathrm{O}_{2}$ concentration is increased in the treatment gas mixture. Work is currently under way to complete analysis of the solid phases of these tests, which will serve to identify treatment products and define the reactions involved.

Characterization activities have also been conducted on Hanford Site chromate-contaminated soil to identify potential solid $\mathrm{Cr}(\mathrm{VI})$ phases. This work suggests that $\mathrm{Cr}(\mathrm{VI})$ may be precipitated with calcite in solid solution and also as barium chromate under certain conditions. We will conduct testing in FY 2002 to determine the degree to which $\mathrm{H}_{2} \mathrm{~S}$ can interact with these solid phases and to assess the effectiveness of treatment that can be attained.

\section{Evaluation of Soil Water Chemistry Role on Reduction of $\mathrm{Cr}(\mathrm{VI})$ by $\mathrm{H}_{2} \mathrm{~S}$}

To understand the role of soil water chemistry for $\mathrm{Cr}(\mathrm{VI})$ reduction, New Mexico Institute of Mining and Technology is examining the reduction kinetics of $\mathrm{Cr}(\mathrm{VI})$ by $\mathrm{H}_{2} \mathrm{~S}$ in the aqueous phase. Analytical methods have been developed for chromate, sulfide, elemental sulfur, sulfite, thiosulfate, and sulfate. $\mathrm{Cr}(\mathrm{VI})$ reduction is being examined as a function of $\mathrm{pH}, \mathrm{Cr}(\mathrm{VI})$ concentration, sulfide concentration, temperature, and ionic strength. Batch experiments with excess $[\mathrm{Cr}(\mathrm{VI})]$ over $\left[\mathrm{H}_{2} \mathrm{~S}\right]_{\mathrm{T}}$ indicated that the molar amount of sulfide required for the reduction of one molar of $\mathrm{Cr}(\mathrm{VI})$ was 1.5 , suggesting the following stoichiometry:

$$
2 \mathrm{CrO}_{4}{ }^{2-}+3 \mathrm{H}_{2} \mathrm{~S}+4 \mathrm{H}^{+} \rightarrow 2 \mathrm{Cr}(\mathrm{OH})_{3(\mathrm{~S})}+3 \mathrm{~S}_{(\mathrm{S})}+2 \mathrm{H}_{2} \mathrm{O}
$$

Further study with transmission electron microscopy and energy-dispersive X-ray spectroscopy confirmed that chromium hydroxide and elemental sulfur were the stable products. We measured the kinetics of $\mathrm{Cr}(\mathrm{VI})$ reduction by hydrogen sulfide under various initial concentrations of $\mathrm{Cr}(\mathrm{VI})$ and sulfide, as well as $\mathrm{pHs}$ controlled by HEPES, phosphate, and borate buffers. Results showed that the overall reaction was second order, i.e., first order with respect to $\mathrm{Cr}(\mathrm{VI})$ and first order to sulfide. The reaction rate increased as $\mathrm{pH}$ was decreased, and the $\mathrm{pH}$ dependence correlated well with the fraction of fully protonated sulfide $\left(\mathrm{H}_{2} \mathrm{~S}\right)$ in the $\mathrm{pH}$ range of 6.5 to 10 . The nature of buffers did not influence the reaction rate significantly in the homogeneous system. The reaction kinetics could be interpreted by a three-step mechanism: formation of an inner-sphere chromate-sulfide intermediate complex $\left(\left\{\mathrm{H}_{2} \mathrm{O}_{4} \mathrm{Cr}{ }^{\mathrm{VI}} \mathrm{S}\right\}^{2-}\right)$, intramolecular electron transfer to form $\mathrm{Cr}(\mathrm{IV})$ species, and subsequent fast reactions leading to Cr(III).

Interestingly, the rate for $\mathrm{Cr}(\mathrm{VI})$ reduction was dramatically accelerated at the later stage of the reaction. The produced elemental sulfur can form particulate sulfur colloids capable of adsorbing sulfide. Such adsorbed sulfide exhibits much higher reactivity towards $\mathrm{Cr}^{\mathrm{VI}}$ reduction than the aqueous phase sulfide and is responsible for the accelerated $\mathrm{Cr}^{\mathrm{VI}}$ reduction observed. 


\section{Assessment of Reductive Buffering Capacity of $\mathrm{H}_{2} \mathrm{~S}$-Reduced Soil and Potential for Emplacement of Long-Term Vadose Zone Reactive Barriers}

We initiated this task in FY 2000 by conducting a column reoxidation test with an $\mathrm{H}_{2} \mathrm{~S}$-treated Hanford soil sample. The test involved pumping oxygenated water through the column until oxygen breakthrough was observed. This permitted calculation of the redox-buffering capacity of the treated soil. This value was found to agree with an estimate based on the ferrous content of the treated soil sample. We have undertaken additional treatment/reoxidation tests in FY 2001. The results of these tests indicate that $\mathrm{H}_{2} \mathrm{~S}$-treated soil has a substantial reducing capacity, and hence, it appears viable to produce a reductive vadose zone barrier.

\section{Planned Activities}

During FY 2001-2002, we plan to obtain additional information needed to support reactive transport modeling activities and design of in situ gaseous reduction field treatment systems. Planned activities include the following:

- The examination of solid-gas phase interactions between synthesized iron oxides (e.g., ferrihydrite and hematite) and $\mathrm{H}_{2} \mathrm{~S}$ through column studies will be completed. The amount of $\mathrm{H}_{2} \mathrm{~S}$ consumed will be determined. The reaction products will be analyzed by Mössbauer, X-ray photoelectron, and far-infrared spectroscopies. This will serve to better define $\mathrm{H}_{2} \mathrm{~S}$ interaction processes in soils.

- Experiments on aqueous phase $\mathrm{Cr}(\mathrm{VI})$ reduction by sulfide under various conditions will be completed, and the reaction mechanism will be explored. In particular, the effect of oxygen will be tested.

- Potential catalysis of mineral surface on $\mathrm{Cr}(\mathrm{VI})$ reduction by sulfide will be examined using pure Fe-, Mn-, Al-, and Si- oxides as representative surfaces. Adsorption of both $\mathrm{Cr}(\mathrm{VI})$ and sulfide will be properly evaluated to understand the catalytic processes.

- Interactions between pure chromate compounds (e.g., $\mathrm{Cr}(\mathrm{VI})$-enriched calcite, $\mathrm{BaCrO}_{4}$, $\mathrm{K}_{2} \mathrm{CrO}_{4}, \mathrm{Na}_{2} \mathrm{CrO}_{4}, \mathrm{CaCrO}_{4}$ ) and $\mathrm{H}_{2} \mathrm{~S}$ gas will be tested. Reaction products will be analyzed by X-ray diffraction, SEM/microprobe, and TEM with parallel electron energy-loss spectroscopy.

- Testing activities will be extended in late FY 2001 to include Tc and in FY 2002 to include $\mathrm{U}$, thus potentially increasing the capabilities of the in situ gaseous reduction approach to remediation. 


\section{Influence of Clastic Dikes on Vertical Migration of Contaminants in the Vadose Zone at Hanford}

(Project Number: 70193)

\section{Principal Investigator}

Christopher J. Murray

Pacific Northwest National Laboratory

P.O. Box 999, MSIN K6-81

Richland, WA 99352

(509) 376-5848 (phone)

Chris.Murray@pnl.gov

\section{Co-Investigators}

John L. Wilson

Department of Earth and Environmental Science

New Mexico Institute of Mining and Technology

Socorro, NM 87801

(505) 835-5308 (phone)

jwilson@nmt.edu

Michael J. Fayer

Pacific Northwest National Laboratory

P.O. Box 999, MSIN K9-33

Richland, WA 99352

(509) 372-6045 (phone)

mike.fayer@pnl.gov

\section{Graduate Students}

Benjamin Lechler, M.S.

Zachary Brown, M.S. 


\section{Research Objective}

This research project addresses the effect of clastic dikes on contaminant transport in the vadose zone. Clastic dikes are vertically oriented subsurface heterogeneities that are common at the Hanford Site, including the subsurface sediments below the tank farms in the 200 West Area. Previous studies have suggested that clastic dikes may provide a fast path for transport of leaking fluid from the tanks through the vadose zone.

This research will test the hypothesis that clastic dikes at the Hanford Site provide preferential pathways that enhance the vertical movement of moisture and contaminants through the vadose zone. Current flow and transport models of the vadose zone at the 200 Areas are based on relatively simple hydrogeologic models that assume horizontally layered sediments with no preferential vertical flow paths. To address those scientific needs, our research includes field and modeling studies of the spatial distribution of clastic dikes, the hydrologic properties within dikes, and the potential effect of clastic injection dikes on fluid flow through the vadose zone. The data and models of the clastic dike networks produced for this project should be directly applicable to fate and transport studies conducted at the 200 West Hanford tank farms.

\section{Research Progress and Implications}

This report summarizes progress after the first 20 months of a 3-year project. In 2000, the project used remote sensing and ground-penetrating radar surveys to describe the large-scale distribution of the clastic dikes along Army Loop Road in the 600 Area and at the 216-S-16 pond. Figure 1 shows the dikes at the two sites as mapped into a geographic information system (GIS) from air photographs. We then used the GIS to extract the lengths, area of the polygons, and azimuth of the dikes, and made simple statistical analyses. In addition, we made four field traverses across the dike swarm and measured the widths of dikes crossed during the traverses. The edges of the dikes were interpreted to be the boundaries where the density of vegetation changed (vegetation is thicker on the dikes than on the host soil because the dikes tend to hold more moisture). Figures 2 through 5 show the distribution of the measured properties. The mean length of the dikes is 62 meters, and the average width of the surface expression of the dikes is just over 2 meters. The rose diagram (Figure 5) indicates a slight preferential orientation to the dikes in the network, with many of the dikes occurring in two conjugate sets. Those sets have north, northwest-south, southeast and north, northeast-south, southwest orientations.

We conducted surface ground-penetrating radar surveys at three areas: square grid surveys were conducted at the Army Loop Road site and at the 216-S-16 pond, and measurements were made on a 6.9 kilometer traverse in the 600 Area (see Figure 1). The surveys helped in mapping the dikes and detecting smaller dikes not visible on air photos or the ground surface. In general, the data quality at the 216-S-16 pond was not good because numerous diffractions in the data interfered with deeper reflections. Those diffractions are probably from cobbles and boulders exposed at the surface and buried in the ground. The data quality of the Army Loop Road survey and the 6.9-kilometer traverse were significantly better. Figures 6 and 7 show examples from the 


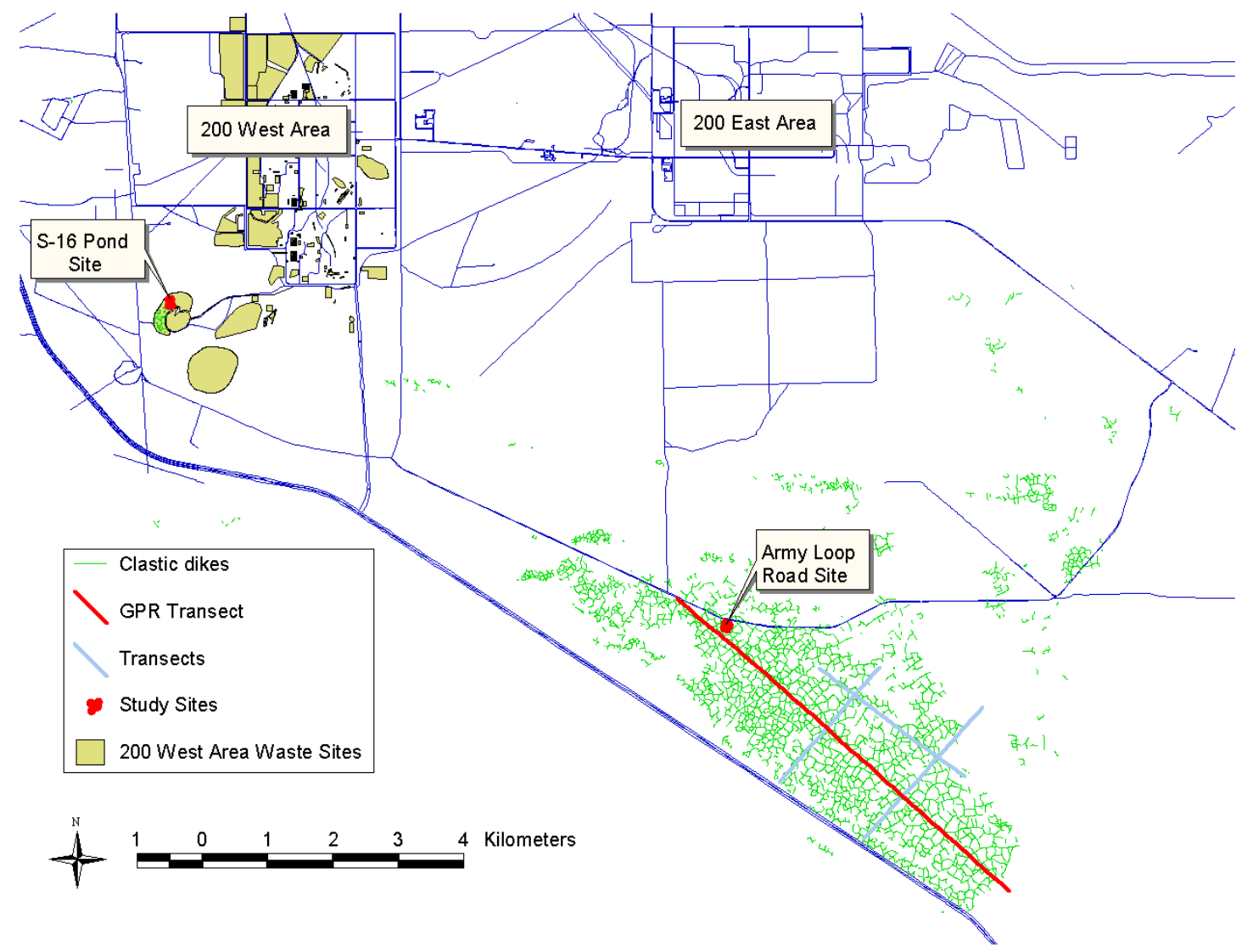

Figure 1. Distribution of Clastic Dikes at the Army Loop Road Site and the 216-S-16 Pond

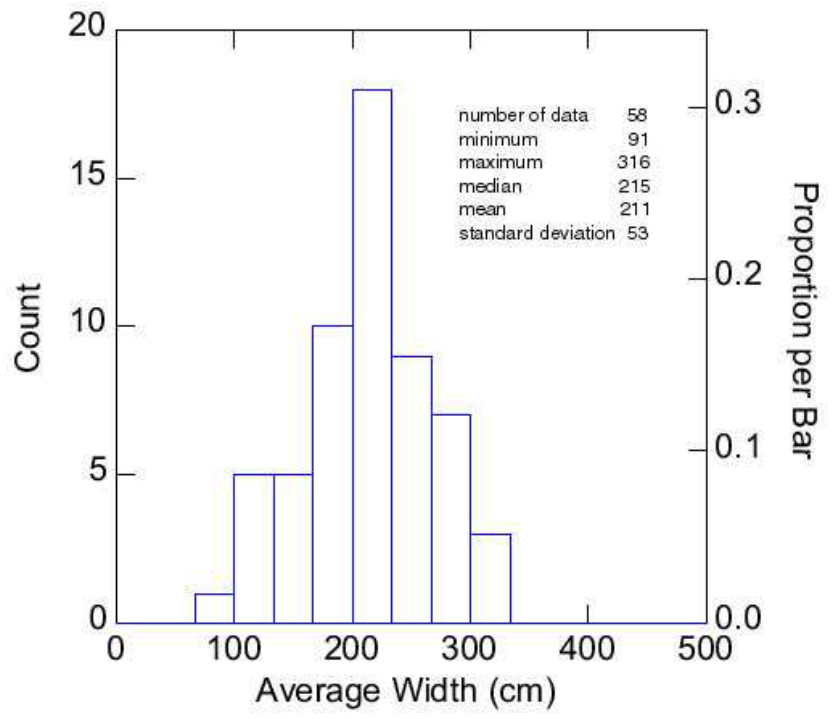

Figure 2. Distribution of Widths of Clastic Dikes at the Army Loop Road Site 


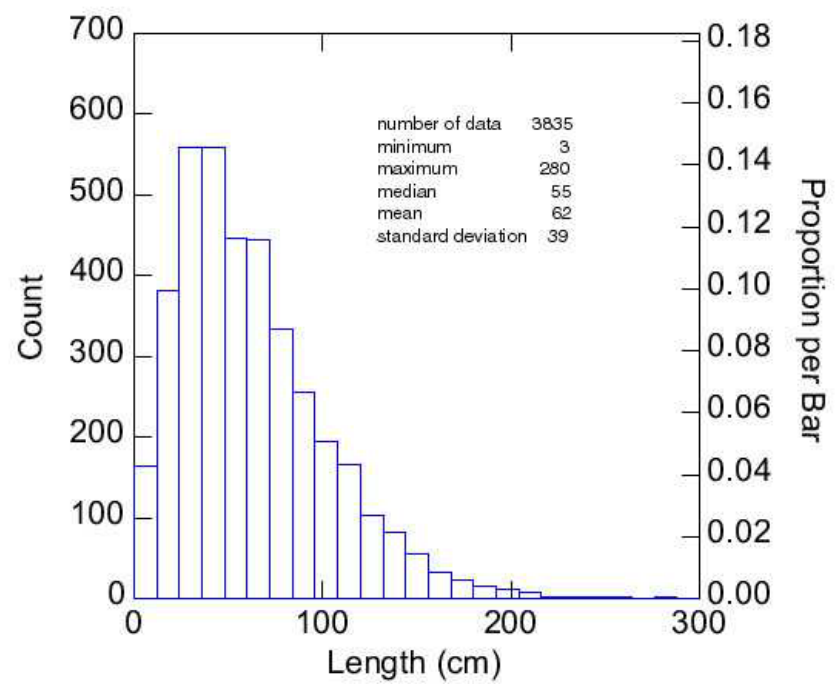

Figure 3. Distribution of Lengths of Clastic Dikes at the Army Loop Road Site

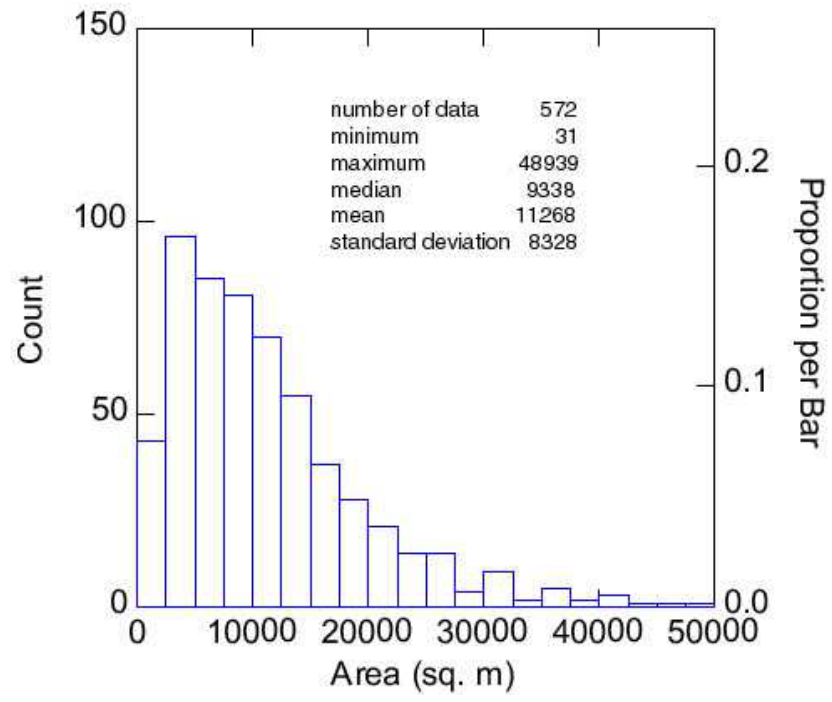

Figure 4. Distribution of Polygon Areas of Clastic Dikes at the Army Loop Road Site 


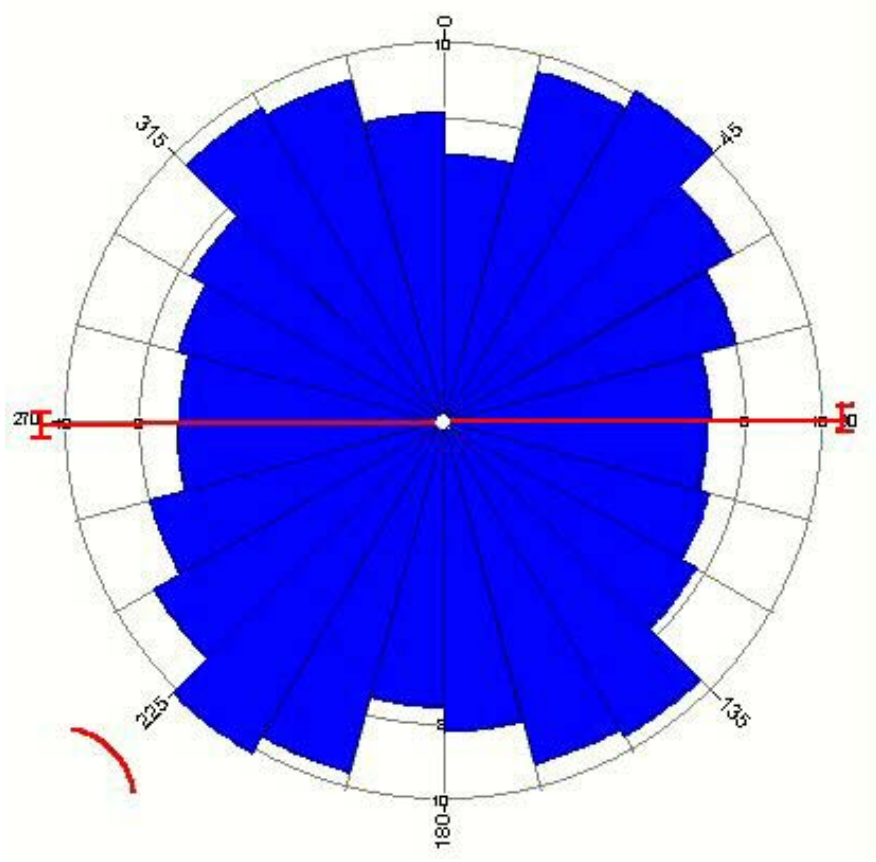

Figure 5. Distribution of Clastic Dike Azimuth at the Army Loop Road Site

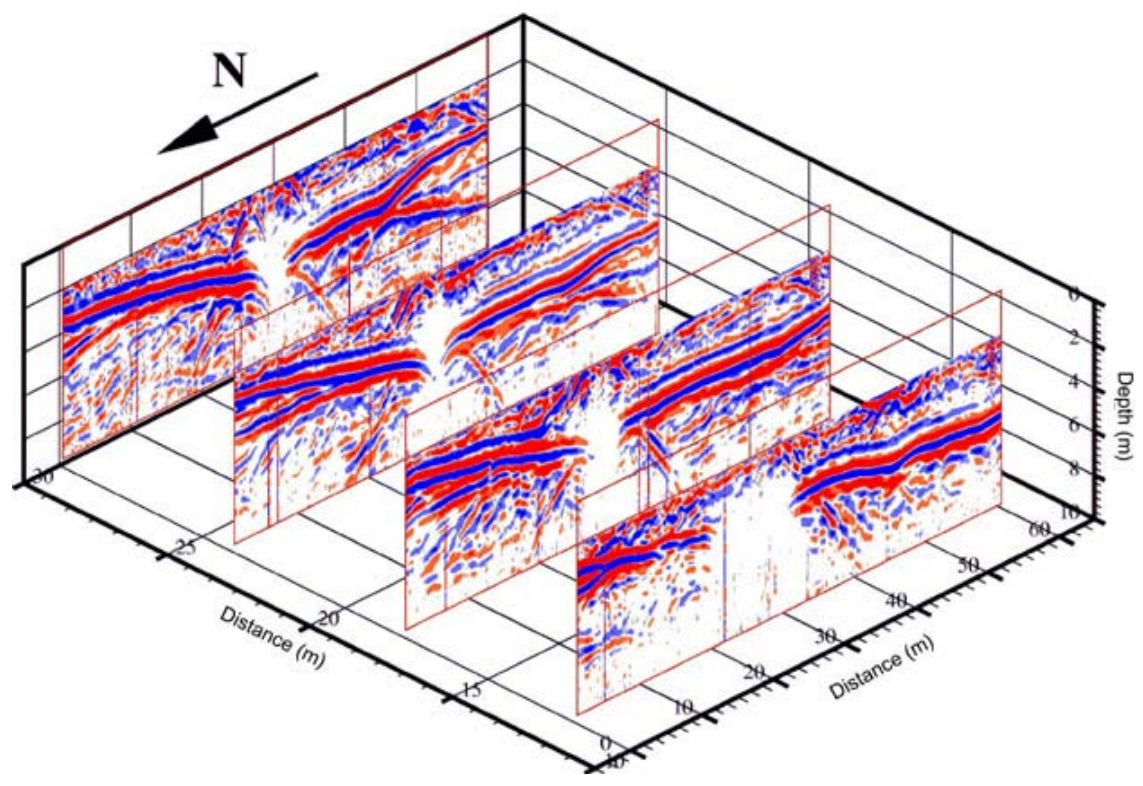

Figure 6. Fence Diagram of the Northeast-Southwest Army Loop Road Profiles 


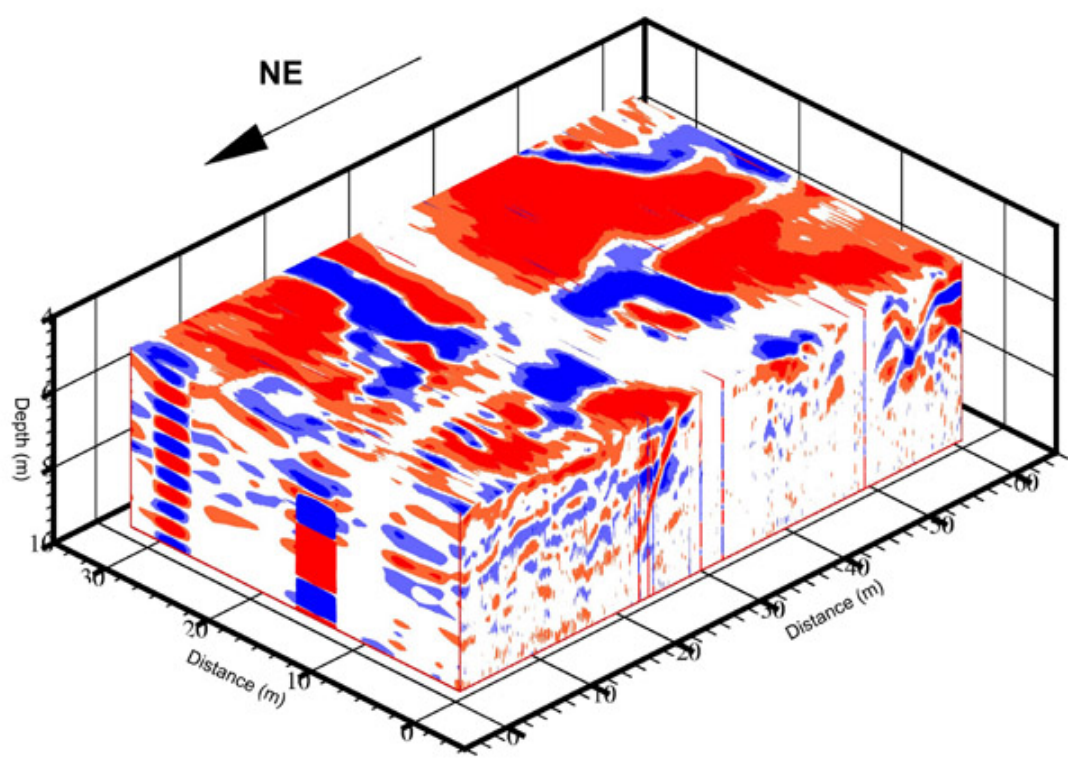

Figure 7. Three-Dimensional Diagram of the Data from the Army Loop Road Survey

ground-penetrating radar survey at Army Loop Road. Figure 6 shows four northeast-southwest profiles. The white area at $\sim 30$ meters distance in the northeast-southwest direction on each traverse is a clastic dike. Figure 7 is a three-dimensional view of the same area. The white area along the plot's surface corresponds to the subsurface expression of a clastic dike. A second dike can be seen at $\sim 10$ meters on the east-west face of the plot. The second dike intersects the first dike near the center of the diagram.

We used the ground-penetrating radar survey and the air photo and field mapping to select a site to trench across a clastic dike. In August 2000, we trenched a clastic dike at the 216-S-16 pond with a backhoe to a depth of $\sim 3.5$ meters (Figure 8 ). The exposed clastic dike is in the sanddominated facies of the Hanford formation. The dike is $\sim 0.7$ meter thick at the bottom of the trench but becomes extremely narrow ( $\sim 8$ to 10 centimeters) within $\sim 1$ meter of the surface. The narrow portion of the dike appears to be reactivation of the dike along an older dike surface. In the exposures made by the lower two lifts, the host material is very different on each side of the dike (see Figure 8). The material to the west of the dike (to the left in Figure 8) is medium to coarse-grained laminated sand containing some silt and sand rip-up clasts. The material to the east of the dike consists of finer-grained, silty fine to medium sand. In addition, a clastic sill (a structure similar to a clastic dike but concordant with horizontal bedding) is exposed east of the dike, near the base of the trench. The sill is seen in Figure 8 as the $\sim 8$-centimeters-thick, finegrained unit to the right of the dike in the lower part of the trench. The heterogeneities within both the host sediment and within the dike complicate comparison of physical property data from samples of dike and host. The trench was dug in four lifts. After each lift, except the first, the 


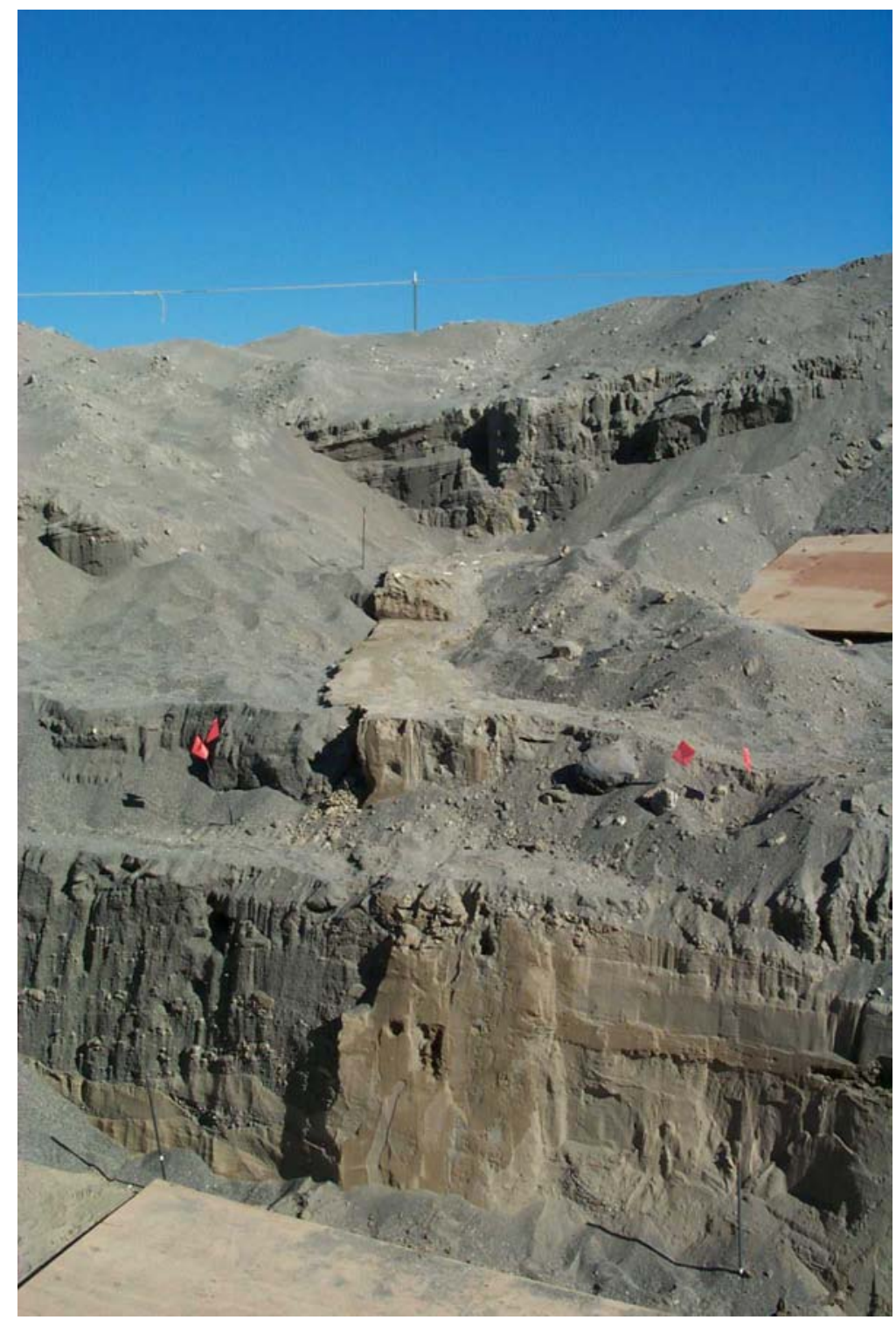

Figure 8. Clastic Dike Exposed in Trench at 216-S-16 Pond

dike and host sediment were characterized by air permeability measurements and infrared imagining. In addition, samples were taken for moisture analyses, grain size distribution, and mineralogy (X-ray diffraction).

Figure 9 shows two composite photographs of the lowest level in the trench. The lower photo is a normal photograph, and the upper photo is infrared. The contrast in the infrared photo is due to variation in the moisture content of the sediment; darker colors indicate more moisture. The dark vertical band on the left side of the infrared photo is the clastic dike, and the dark horizontal band 

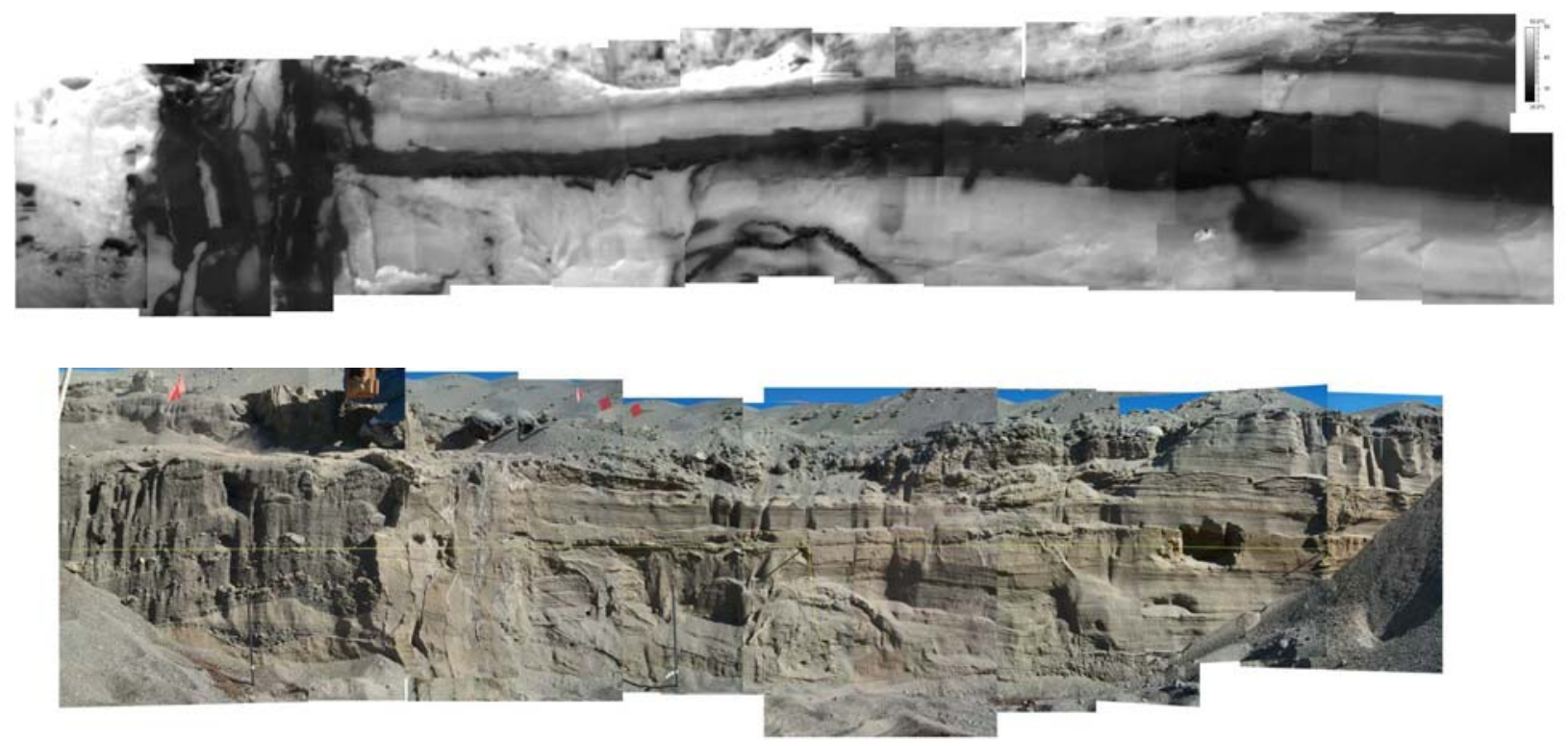

Figure 9. Composite Photographs of the Lower Part of the Trench at the 216-S-Pond. The upper photo is an infrared image and the lower photo is a normal photograph.

is the clastic sill. An attempt will be made to calibrate the infrared data to the air permeability moisture data. Several hundred air permeability measurements were obtained from the exposures in the trench.

Figure 10 shows the distribution of the air permeability results. The dike and sill exposed in the trench tend to be finer-grained than the host material and therefore have a higher moisture content and lower permeability than the host material. Figure 11 shows a box plot comparing the moisture content in the dike and host materials. Moisture content was determined gravimetrically from samples collected at the trench.

We collected samples from the dike and host sediment to compare the mineralogy and grain size distribution between the dike and host sediment. Qualitative X-ray diffraction analysis of 21 samples showed that the mineral composition of both the dike and the host sediment is dominated by quartz and plagioclase feldspar. Lesser amounts of pyroxene, mica, chlorite, and amphibole are also present in most samples. Calcite was identified in only three samples. No apparent differences were found in the mineral composition between the dike and host sediment. We submitted 19 samples for analysis of particle size distribution. In general, the samples from the dike tend to be much finer-grained than are samples of host sediment.

In addition to the above tests, we conducted drip-irrigation and dye-tracer studies at the excavation. Vertical time-domain reflectometry probes, 0.25 meter long, were driven into the exposed horizontal face at 0.15 meter back from the exposed vertical face. These probes were spaced every 0.3 meter along the traverse. Horizontal probes, 0.5 meter long, were driven into the exposed vertical face in a grid with spacings of 0.3 meter horizontally and 0.15 meter 


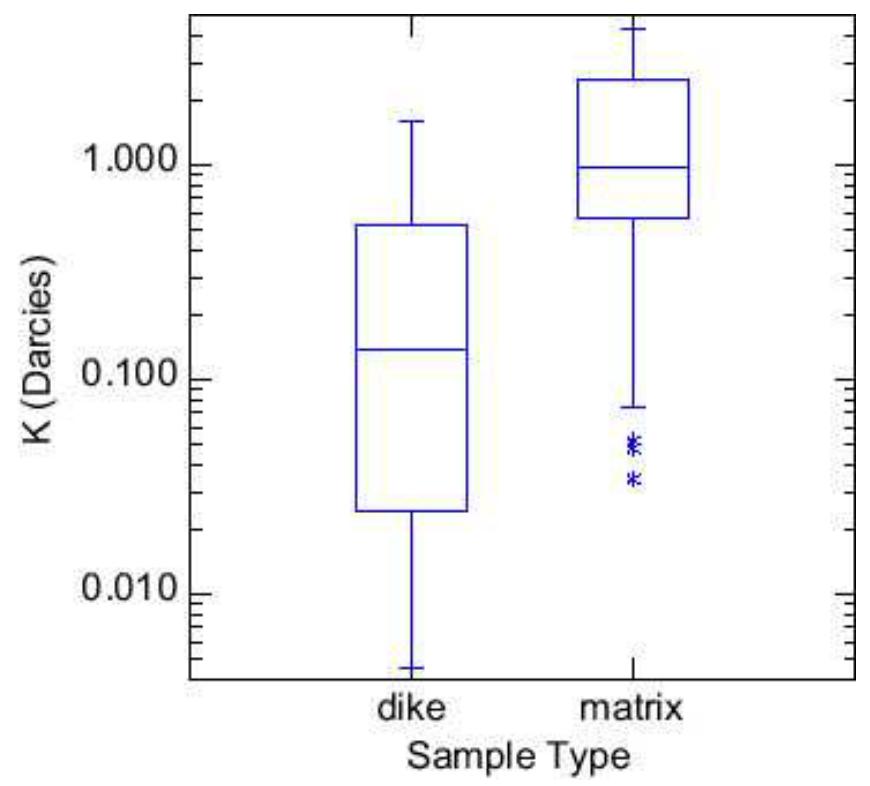

Figure 10. Air Permeability Data from Dike and Host Sediment at 216-S-16 Pond

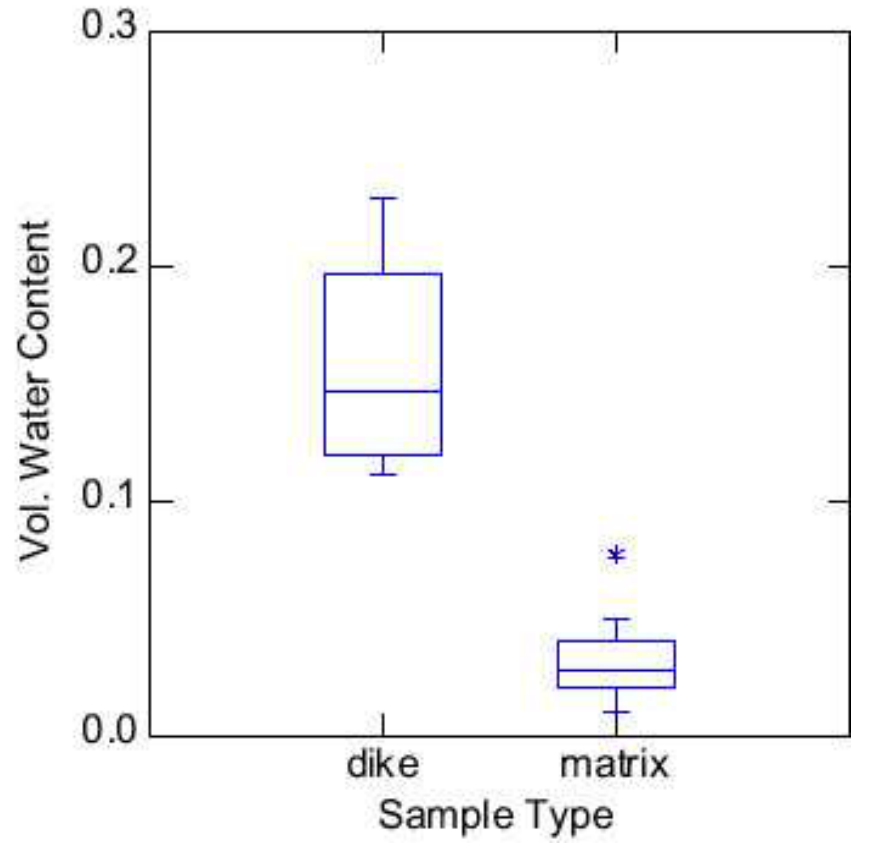

Figure 11. Gravimetric Water Content of Samples Collected from the Dike and Host Sediment at 216-S-Pond 
vertically. A drip irrigation system with lines spaced $\sim 5$ centimeters apart was used to uniformly deliver known amounts of water. We measured several parameters during the experiment.

Volumetric water content was monitored along the surface and the cut face. Soil-water pressure head was monitored with tensiometers along the bench surface, and field-saturated conductivity was measured every 0.15 meter along the bench surface using a tension infiltrometer. In addition, we collected soil samples on a 15-by-15 centimeter grid on the cut face to analyze for particle-size distribution.

Five injections of water were applied, totaling 738 liters. Brilliant Blue dye was mixed with the water for the last injection. Figure 12 shows the distribution of soil moisture three days after the first injection. The figure shows that the wetting front appears deeper in the dike than in the relatively coarser-grained host sediment. This is partly due to capillary wicking of the finer sediment in the dike. The water was applied so that the soil remained unsaturated; therefore, capillary wicking was quite important. After nearly a week, the entire exposed face on the west of the dike was visibly wet to a depth of greater than 1 meter, while on the east side the sediment appeared to be uniformly wet to a depth of $\sim 75$ centimeters, or $\sim 20$ centimeters below the bottom of the horizontal clastic sill.

Figure 13 shows the distribution of dye 1 day after injection and 8 days after we initiated prewetting. The dye injection preferentially infiltrates the coarser-grained parts of the dike and the coarse-grained host sediment. The dye trace results suggest that clastic dikes containing fine sediment may actually retard vertical flow rather than act as conduits to fluids applied at the upper surface of the dike. The results also suggest that such features may act as vertical cutoff walls, limiting the horizontal spread of fluids that otherwise could move significant distances laterally in response to large-scale anisotropic features such as graded horizontal layering, which is typical of most Hanford sediment.

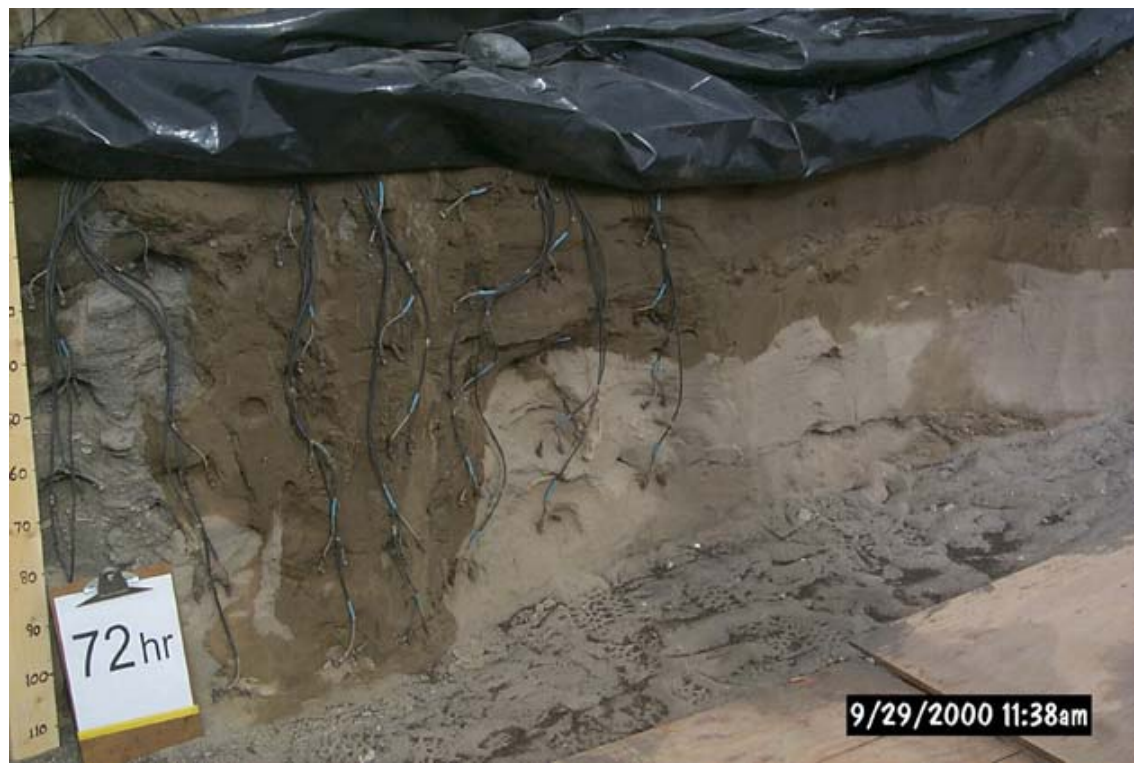

Figure 12. Distribution of Soil Moisture Three Days after the first Injection of Water 


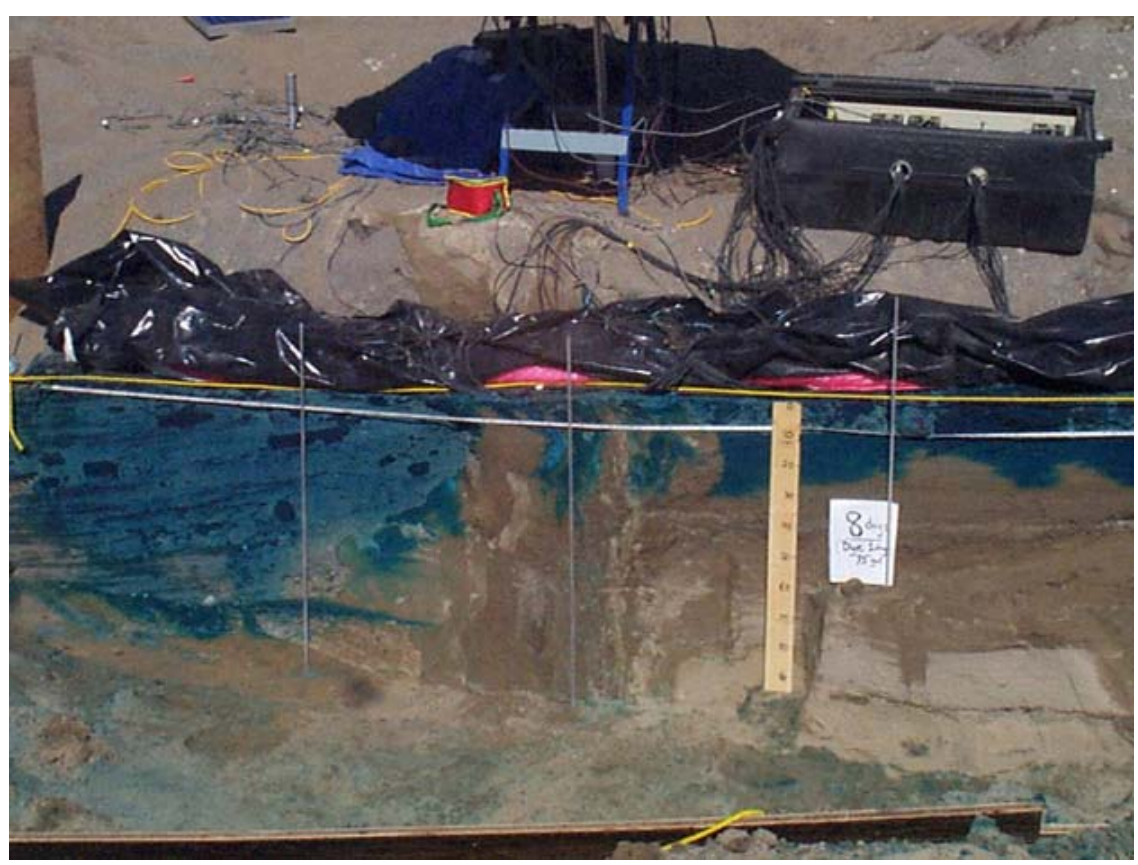

Figure 13. Dye and Water Distribution in Clastic Dike and Adjacent Host Sediment 1 Day after Dye Injection and 8 Days after Prewetting

\section{Planned Activities}

Additional field work will be conducted at the Hanford Site through July of 2001, at the Army Loop Road field location (Figure 1). We are conducting a large-scale infiltration experiment covering an area of about $30 \mathrm{~m}^{2}$ at a site containing a clastic dike. During the infiltration experiment, we will monitor migration of water and tracers in the vadose zone with a suite of advanced and standard geophysical methods (cross borehole radar tomography, time domain reflectometry [TDR], and neutron probes). We will use the data collected from this experiment to derive flow and transport parameters for the dike and surrounding matrix, as well as provide field data with which to perform geostatistical and hydraulic flow modeling. Following the infiltration test, we will characterize the physical and hydraulic properties of the site by excavating the clastic dike adjacent to the infiltration site and conducting in situ tests (e.g., air permeability, visual observation, infrared imaging, tension infiltrometer) and by taking samples for standard laboratory analyses of physical and hydraulic properties. We will use geostatistical methods in late FY 2001 and in FY 2002 to produce numerical three-dimensional grids of the infiltration site for flow and transport modeling of the vadose zone. We will perform flow and transport modeling in FY 2002, and the resulting transport models will be compared with the observations made during the transport experiments. 


\section{Quantifying Vadose Zone Flow and Transport Uncertainties Using a Unified, Hierarchical Approach}

(Project Number: 70187)

\section{Principal Investigator}

Philip D. Meyer

Pacific Northwest National Laboratory

Battelle Portland Office

Portland, OR

503-417-7552 (phone)

503-417-2175 (fax)

philip.meyer@pnl.gov

Co-Investigators

Chris J. Murray

Pacific Northwest National Laboratory

P.O. Box 999, MSIN K6-81

509-376-5848 (phone)

509-376-5368 (fax)

chris.murray@pnl.gov

Mark L. Rockhold

Pacific Northwest National Laboratory

P.O. Box 999, MSIN K9-33

541-737-5410 (phone)

rockhold@engr.orst.edu

\section{Graduate Student}

Marcel Schaap, post-doctoral 


\section{Research Objective}

The objective of this research is to develop and demonstrate a general approach for modeling flow and transport in the heterogeneous vadose zone. The approach uses similar media scaling, geostatistics, and conditional simulation methods to estimate soil hydraulic parameters at unsampled locations from field-measured water content data and scale-mean hydraulic parameters determined from available site characterization data. Neural network methods are being developed to estimate soil hydraulic parameters from more easily measured physical property data such as bulk density, organic matter content, and percentages of sand, silt, and clay (or particle-size distributions). Field water content distributions are being estimated using various geophysical methods including neutron moderation, ground-penetrating radar, and electrical resistance tomography. One of the primary goals of this research is to determine relationships between the type of data used in model parameterization, the quantity of data available, the scale of the measurement, and the uncertainty in predictions of flow and transport using these methods. Evaluation of the relationships between available data, scale, and uncertainty will use primarily existing data from large-scale, controlled experiments.

\section{Research Progress and Implications}

This report summarizes work completed after 1.5 years of a 3-year project. A large-scale injection experiment was conducted in summer 2000 as part of another project, on the Hanford Site where a previous injection experiment had been conducted in 1982. The site was already instrumented from the 1982 experiment with thirty-two 18-m-deep wells arranged radially around a central injection well. Various other types of instrumentation were installed as part of a separate project for the experiment conducted in 2000. These instruments included access tubes of polyvinyl chloride to provide access for cross-borehole ground-penetrating radar (GPR), tensiometers for measurement of soil water pressure head, and other equipment. Six separate injections of water were made during the experiment, at a depth of approximately $4.6 \mathrm{~m}$ below ground surface. The instruments described above were used to quantify the dynamics of the water plume.

Prior to the injections, three additional boreholes were emplaced at the site, and core samples were collected from these boreholes using a split-spoon sampler as part of our EMSP project. Subsamples were collected from approximately 60 of these cores. These subsamples were used to determine bulk densities, porosities, particle-size distributions, water retention characteristics, saturated hydraulic conductivities, and unsaturated hydraulic conductivities at the U.S. Salinity Laboratory in Riverside, California. These data and other physical and hydraulic property data sets from the Hanford Site are being used in neural network analyses to develop correlations and so-called pedotransfer functions to relate the more easily determined physical property data to the measured hydraulic properties at the site. The data also have been used to estimate hydraulic property model parameters and parameter distributions and for scaling analyses to estimate scalemean hydraulic parameters for use in numerical modeling of the injection experiment. 
In 1995, Schlumberger well-logging services logged the 32 wells at the experimental site using various tools, including neutron probes and a litho-density sonde (LDS), for estimating water content and wet density, respectively. The LDS data were collected at 2.5 -cm-depth intervals to a depth of approximately $18 \mathrm{~m}$. Neutron probe data from the experiment conducted in 2000 were collected at $30-\mathrm{cm}$-depth intervals. The revised LDS data were reanalyzed and correlated with the neutron probe data so that the LDS data can be used to estimate both water contents and porosities at the $2.5-\mathrm{cm}$-depth resolution. The spatial auto- and cross-correlation structures of the initial (pre-injection) water content and porosity data are being analyzed for use in the development of high-resolution geostatistical models of the water content and porosity distributions at the site. Conditional simulations of the water content and porosity fields will be generated using sequential Gaussian or indicator simulation methods. The generated fields will span a domain that is $20-\mathrm{m}$ wide on each side and 12-m deep. This domain will be discretized with approximately 3 million nodes.

\section{Planned Activities}

The high-resolution water content and porosity fields will be used in conjunction with the scalemean hydraulic properties determined from the core samples to parameterize a three-dimensional flow and transport model (STOMP90). This model will then be used to simulate the field experiment. The high-resolution model results will be used as a reference for comparison with results obtained using upscaled model parameters and for alternative parameterizations based on the neural network analyses and other types of data. The results from these simulations will be compared to evaluate the relationships between the type of data used in model parameterization, the quantity of data available, the scale of the measurement (or grid block size), and the uncertainty in predictions of flow and transport using these methods.

\section{Information Access}

Details regarding the field experiment and geophysical data used for model parameterization and testing can be found at http://etd.pnl.gov:2080/vadose/. 


\section{Radionuclide Sensors for Water Monitoring}

(Project Number: 70179)

\section{Principal Investigator}

Jay W. Grate

Pacific Northwest National Laboratory

P.O. Box 999, MSIN K8-93

Richland, WA 99352

(509) 376-4242 (phone)

(509) 376-5106 (fax)

jwgrate@pnl.gov

\section{Co-Investigators}

Oleg B. Egorov

Pacific Northwest National Laboratory

P.O. Box 999, MSIN P7-22

Richland, WA 99352

(509) 376-3485 (phone)

(509) 372-2156 (fax)

oleg.egorov@pnl.gov

Timothy A. DeVol

Clemson University

Clemson, SC 29634-0919

(864) 656-1014 (phone)

tim.devol@ces.clemson.edu

\section{Graduate and Undergraduate Students}

James E. Roane, Ph.D.

Hui Tan, Ph.D.

Lara Drumm, M.S.

Jenny Masters, junior, Chemical Engineering

Tobias Gemm, junior, Environmental Planning

Sunil Bector, junior, Biological Systems Engineering 


\section{Research Objective}

Radionuclide contamination in the soil and groundwater at U.S. Department of Energy (DOE) sites is a severe problem requiring monitoring and remediation. Radionuclide measurement techniques are needed to monitor surface waters, groundwater, and process waters. Typically, water samples are collected and transported to the analytical laboratory where costly radiochemical analyses are performed. To date, there has been very little development of selective radionuclide sensors for alpha- and beta-emitting radionuclides such as ${ }^{90} \mathrm{Sr},{ }^{99} \mathrm{Tc}$, and various actinides of interest.

The objective of this project is to investigate novel sensor concepts and materials for sensitive and selective determination of beta- and alpha-emitting radionuclide contaminants in water. To meet the requirements for low-level, isotope-specific detection, the proposed sensors are based on radiometric detection. As a means to address the fundamental challenge of short ranges of beta and alpha particles in water, our overall approach is based on localization of preconcentration/separation chemistries directly on or within the active area of a radioactivity detector, using automated microfluidics for sample manipulation and sensor regeneration or renewal.

The outcome of these investigations will be the knowledge necessary to choose appropriate chemistries for selective preconcentration of radionuclides from environmental samples, new materials that combine chemical selectivity with scintillating properties, new materials that add chemical selectivity to solid-state diode detectors, new preconcentrating column sensors, and improved instrumentation and signal processing for selective radionuclide sensors. New knowledge will provide the basis for designing effective probes and instrumentation for field analytical chemistry.

\section{Research Progress and Implications}

This report summarizes work through the first 1.5 years of a 3-year program. The initial ongoing effort is directed at the investigation of the preconcentration column sensor concepts, development and characterization of the selective scintillating microspheres (SSMs), and development of the new scintillation detection systems. The preconcentrating minicolumn radionuclide sensor is based on the use of dual-functionality bead materials. These materials are designed to incorporate both selective separation chemistry for analyte preconcentration and localization within the detector, and scintillating properties, so that radioactivity of retained species can be converted to a measurable light output. To date, we have achieved progress in SSM materials prepared by co-immobilization of selective organic extractants and scintillating fluors within inert macroporous polymeric beads, immobilization of selective organic extractants on scintillating glass, and by physically mixing sorbent and scintillating bead materials to yield mixed-bed sensor column. Scintillating sensor materials selective for Tc, Sr, and actinides were prepared and evaluated. 
Using pertechnetate-selective scintillating beads prepared by co-immobilization of selective extractants and scintillating fluors, we have demonstrated the application of SSM resins for the on-line characterization of ${ }^{99} \mathrm{TcO}_{4}{ }^{-}$(pertechnetate) in acidified groundwater. For on-line measurements, the resin is used in conjunction with an on-line flow-cell scintillation detector and an automated fluid handling system. The results of these tests clearly indicate that pertechnetate can be readily detected in acidified groundwater samples below the U.S. Safe Drinking Water Act maximum concentration level of $900 \mathrm{pCi} / \mathrm{L}$. Nevertheless, long-term material stability and analysis of the unacidified groundwater remain to be problematic when using these sensor materials. To address these challenges, we are evaluating sensor configurations based on a mixed-bed column of anion exchange and polymer scintillator beads. Using mixed-bed sensor columns, we demonstrated the feasibility of ${ }^{99} \mathrm{Tc}$ sensing in unacidified groundwater with detection efficiency of $25 \%$ and excellent long-term sensor column stability. This approach appears especially promising for the development of a ${ }^{99} \mathrm{Tc}$ sensor probe suitable for down-well groundwater monitoring.

Research has commenced on preconcentrating column sensors for monitoring of radiostrontium in aqueous solutions. Strontium-selective dual-functionality sensor materials based on crownether extractant have been realized as 1) a mixed bed of extraction chromatographic resin and granular scintillator, 2) extraction chromatographic material coated on the surface of a scintillating glass, and 3) SSMs prepared by co-immobilization of fluors and extractants. As with the pertechnetate on-line measurements, the resin is used in conjunction with a flow-cell scintillation detection and automated fluid handling system. Degradation of the strontium-SSM with continuous reuse was observed but was not as significant as in the case of ${ }^{99} \mathrm{Tc}$. We have characterized the detection efficiency, minimum detectable concentration, selectivity, loading capacity, capacity factor, and regeneration capability of these dual-functionality resins for ${ }^{89,90} \mathrm{Sr}$ quantification. One of the limitations of the crown ether-based separation chemistry is the need for significant sample acidification. Separation chemistries that work in dilute acid or under groundwater pHs would be advantageous. We evaluated solid-phase extraction and inorganic sorbent materials for the purpose of $\mathrm{Sr}$ capture from groundwater. These two materials were capable of efficient Sr uptake from groundwater without the need for sample acidification. Mixed-bed column sensors are being evaluated using these sorbent chemistries. Detection efficiencies as high as 50\% were observed, and sensor regeneration was possible.

We have developed and characterized actinide-SSMs to determine feasibility for sequential elution of radioactive species and gross alpha-radiation monitoring. Tests have indicated that sequential separation is feasible using actinide-selective SSM, with results comparing well with standard radiochemical techniques. The absolute detection efficiency of the actinide-SSM depends on alpha energy and ranges from $\sim 80 \%$ to nearly $100 \%$. For gross alpha-radiation monitoring, we have investigated extractive scintillator resins using actinide-selective extractant and actinide-selective chelating resin. Both separation chemistries exhibit strong affinity for tri-, tetra- and hexavalent oxidation state actinides in dilute acids. Scintillation functionality was introduced by 1) producing a mixed-bed of plastic scintillator or scintillating glass beads and extraction chromatographic resin, 2) loading extractant on inorganic scintillator beads, and 
3) introducing scintillation fluors during polymerization and/or by impregnating polymer beads with scintillator fluors. The real-time quantification of natural uranium in groundwater was demonstrated using actinide-selective SSMs.

Development of a flow-cell detection system with digital data acquisition continues. The photomultiplier tube approach to scintillation light detection followed by complete digital signal processing has been demonstrated. The development of a photodiode (PD) approach is nearly complete, but we did not reap the benefit that we had hoped. Because there is no gain associated with the PD, signals from the PDs were amplified and shaped by Canberra 2004 charge-sensitive preamplifier and Princeton Gamma-Tech linear amplifier before being connected to the digital oscilloscope. We achieved pulse shape discrimination of the Parylene C coated CsI:Tl granular scintillator using the zero-crossing technique. The alpha-particle interactions in the scintillator resulted in a signal that was easily digitized. The beta interactions in the scintillator resulted in a signal that was only slightly above the noise level of the $\mathrm{PD}$, making signal processing problematic. To be able to use the PD system, the PD will need to be cooled to decrease the thermonic noise. Alternatively, an avalanche photodiode or hybrid photomultiplier tube must be used to increase the signal. We are currently evaluating our options to determine if the compact size and reduced power consumption of the PD approach outweighs the decreased signal-tonoise.

During the summer of 2000, Tim DeVol from the Clemson team spent a week with Oleg Egorov at Pacific Northwest National Laboratory. This visit targeted research on chemically modified diode detectors for environmental monitoring of alpha-radiation. We solved some critical problems regarding diode packaging and operation in contact with solution, signal processing, and signal-to-noise. However, further work is necessary regarding the reaction kinetics and optimization of the flow cell for efficient analyte capture on the diode surface.

\section{Planned Activities}

During the remainder of the second and third years, we will direct our activities at further development of SSM materials and sensor configurations for ${ }^{99} \mathrm{Tc},{ }^{90} \mathrm{Sr}$, and actinides as well as fundamental understanding of the radiation interaction and light collection efficiency of the dualfunctionality sensor materials. Development of scintillating materials with reduced leaching of the fluor will continue. We are investigating alternatives to manufactured scintillating macroporous resin. We plan to collaborate with the University of Arkansas, Little Rock to investigate the feasibility of producing dual-functionality composite materials using microencapsulation technology. We are beginning to develop and apply stochastic modeling techniques to better understand the radiation energy deposition in a heterogeneous flow-cell detector as well as the light collection efficiency. We will continue research on chemically selective diode detection for quantification of alpha and beta emitters in solution. 


\section{Information Access}

DeVol TA. 2000. "Chromatographic Separation and Measurement of Charged-Particle Emitting Radionuclides," Eichrom Technologies, Inc. Eastern Users' Group Workshop, Augusta, Georgia (May 16, 2000).

DeVol TA, JM Duffey, and A Paulenova. 2000. "Combination Extraction Chromatography and Scintillation Detection Resin for Quantification of Strontium in Aqueous Solutions," presented at Spectrum 2000, Chattanooga, Tennessee (September 24-28, 2000).

DeVol TA, OB Egorov, JE Roane, A Paulenova, and JW Grate. 2000. "Extractive Scintillating Microspheres for ${ }^{89,90} \mathrm{Sr}$ Quantification in Aqueous Solutions," presented at Gordon Conference on Nuclear Waste and Energy, New London, New Hampshire (July 16-21, 2000).

DeVol TA, JE Roane, JM Williamson, JM Duffey, and JT Harvey. 2000. "Development of Scintillating Extraction Media for Separation and Measurement of Charged-Particle Emitting Radionuclides in Aqueous Solutions," Radioactivity and Radiochemistry, 11(1):34-46).

DeVol TA, JM Duffey, and A Paulenova. 2001. "Combined Extraction Chromatography and Scintillation Detection for On-line and Off-line Monitoring of Strontium in Aqueous Solutions," presented at the Fifth International Conference on Methods and Application of Radioanalytical Chemistry, Kailua-Kona, Hawaii, April 9-14, 2000, and accepted for publication in Journal of Radioanalytical and Nuclear Chemistry, Vol. 249, No. 2.

DeVol TA, OB Egorov, JE Roane, A Paulenova, and JW Grate. 2001. "Extractive Scintillating Microspheres for ${ }^{99}$ Tc Quantification in Aqueous Solutions," presented at the Fifth International Conference on Methods and Application of Radioanalytical Chemistry, Kailua-Kona, Hawaii, April 9-14, 2000, and accepted for publication in Journal of Radioanalytical and Nuclear Chemistry, Vol. 249, No. 1.

DeVol TA, JE Roane, and JD Leyba. 2001. "Application of Extractive Scintillator Resins to Quantification of Beta-Emitting Radionuclides in Aqueous Solutions," presented at LCS 2001, Karlsruhe, Germany (May 7-11, 2001) and submitted to Radiocarbon for publication.

Drumm L and TA DeVol. 2001. "Gross Alpha Radiation Monitoring in Natural Waters," presented at LCS 2001, Karlsruhe, Germany (May 7-11, 2001).

Egorov OB, SK Fiskum, MJ O'Hara, and JW Grate. 1999. "Radionuclide Sensors Based on Chemically Selective Scintillating Microspheres: Renewable Column Sensor for Analysis of ${ }^{99}$ Tc in Water," Anal. Chem. 71, 5420-5429.

Egorov OB and JW Grate. 2000. "Automating Analytical Separations in Radiochemistry," presented at the Gordon Conference on Nuclear Waste and Energy, New London, New Hampshire, July 16-21. 
Egorov OB and JW Grate. 2000. "Automated Radionuclide Separations, Analysis and Sensing," presented at the 46th Annual Conference on Bioassay, Analytical, and Environmental Radiochemistry, November 12-17, 2000, Seattle, Washington.

Roane JE and TA DeVol. 2001. "Scintillating Extraction Chromatography Coupled with Pulse Height Spectrum Analysis for Actinide Separation and Analysis," presented at the 2001 American Radiation Safety Conference \& Exposition, Cleveland, Ohio (June 10-14, 2001).

Tan H and TA DeVol. 2000. "Development of a Digital Alpha/Beta Pulse Shape Discriminating System Utilizing CsI(Tl)/Photodiode," presented at the 44th annual meeting of the Health Physics Society, Denver, Colorado (June 24-29, 2000).

Tan H, RA Fjeld, and TA DeVol. 2000. "Digital Alpha/Beta Pulse Shape Discrimination of CsI:Tl for On-Line Measurement of Aqueous Radioactivity," IEEE Trans. Nuc. Sci., 47(4):1516-1521. 


\section{Integrated Field, Laboratory, and Modeling Studies to Determine the Effects of Linked Microbial and Physical Spatial Heterogeneity on Engineered Vadose Zone Bioremediation}

(Project Number: 70165)

\section{Principal Investigator}

Fred Brockman

Pacific Northwest National Laboratory

P.O. Box 999, MSIN P7-50

Richland, WA 99352

509-376-1252 (phone)

fred.brockman@pnl.gov

Co-Investigator

John Selker

Oregon State University

Gilman Hall 240

Corvallis, OR 97330

541-737-6304 (phone)

selkerj@engr.osu.edu

\section{Graduate Students and Research Assistants}

Steven Bradley, post-doctoral

Mark Rockhold, post-doctoral

Rockie Yarwood, post-doctoral

Tina Spadoni, B.S., research assistant

Michael Niemet, M.S., research assistant

Nisha Kapadia, B.S.

Thomas Perry, B.S. 


\section{Research Objective}

In situ bioremediation of contaminants can offer advantages in cost, speed, public acceptance, and final cleanup levels achieved relative to physical removal methods. However, microbial populations in the unsaturated zone are spatially discontinuous and sparse, especially in deep vadose zones and in arid climates with very low moisture and nutrient flux. In addition, there is a lack of knowledge on 1) the ability of microbes to colonize "empty" regions of the vadose zone in response to nutrient delivery and 2) how microbial colonization is controlled by hydrologic and physical features. These issues raise questions about the feasibility of deep vadose zone bioremediation and the accuracy of flow and transport models for vadose zone bioremediation.

The goal of this research is to provide DOE with an increased understanding of the effect of interacting hydrologic and microbiological processes that control the feasibility of engineered bioremediation of chlorinated compounds in heterogeneous, microbially sparse deep vadose zones. The specific objectives are

- to conduct laboratory research on vadose zone microbial colonization processes as a function of hydrologic and physical features and use the information to develop an improved vadose zone reactive transport model

- to evaluate a gas-phase nutrient delivery approach for enhancing removal of carbon tetrachloride from the vadose zone.

\section{Research Progress and Implications}

This report summarizes the progress achieved during the first 20 months of a 3 -year project. Field sampling at the Hanford Site 216-Z-9 trench (contaminated with carbon tetrachloride and transuranic radionuclides), originally scheduled for the beginning of the project (fall/winter 1999), was delayed until late May and early June 2001. Twenty-four core samples ranging in depth from 102 to $187 \mathrm{ft}$ below ground surface are being collected. The field sampling is to determine 1) what types of microbial metabolisms exist throughout the depth profile, 2) the ability of indigenous microorganisms to grow using gaseous sources of nitrogen, phosphorus, and carbon, and 3) the ability of indigenous microorganisms to degrade carbon tetrachloride.

In the interim, research has focused on unsaturated model porous media systems. Research tasks under way at Pacific Northwest National Laboratory are addressing the ability of microbes to colonize uninhabited porous media under static unsaturated conditions. At Oregon State University, researchers are examining the dynamics of microbial metabolic and colonization processes under flowing unsaturated conditions. Both efforts involve understanding how microbial colonization is controlled by porous media water content and particle size.

Microbial motility - the ability of microorganisms to swim through water or move over surfaces - has been largely discounted as unimportant in microbial colonization of the subsurface. However, no specific studies of microbial motility under vadose zone conditions are 
reported in the literature. Our research shows that motile bacteria can colonize rapidly in static (no flow) unsaturated porous media. This adds to the existing base of scientific knowledge on phenomena under unsaturated conditions and challenges conventional scientific wisdom.

Specifically, in 1-mm-diameter sand, two species of Pseudomonas bacteria (one that degrades carbon tetrachloride) migrated upward in columns at initial rates of $5 \mathrm{~cm} / \mathrm{h}$ in porous media columns at a calculated average water film thickness of $70 \mu \mathrm{m}$ (equivalent to $20 \%$ volumetric water content, $\mathrm{vWC}$ ). Initial migration rates were 0.03 to $0.07 \mathrm{~cm} / \mathrm{h}$ at a calculated average water film thickness of $18 \mu \mathrm{m}$ (equivalent to $5 \% \mathrm{vWC}$ ). These rates were achieved by (previously well-fed) cells in the absence of nutrients in the column, as well as by cells in the presence of nutrients in the column. Migration ceased after several days in the absence of nutrients in the column. Migration was not detected at a calculated average water film thickness of $4 \mu \mathrm{m}$ (equivalent to $1.3 \% \mathrm{vWC}$ ) regardless of whether nutrients were absent or present in the column, demonstrating that very low water contents prevent motility-driven colonization (Figure 1). The significance of these results is that nutrient delivery to coarse-grained regions of the vadose zone could promote colonization by motile bacteria. If the motile bacteria were able to degrade contaminants, colonization of previously "empty" regions would dramatically increase the rate and efficiency of biodegradation.

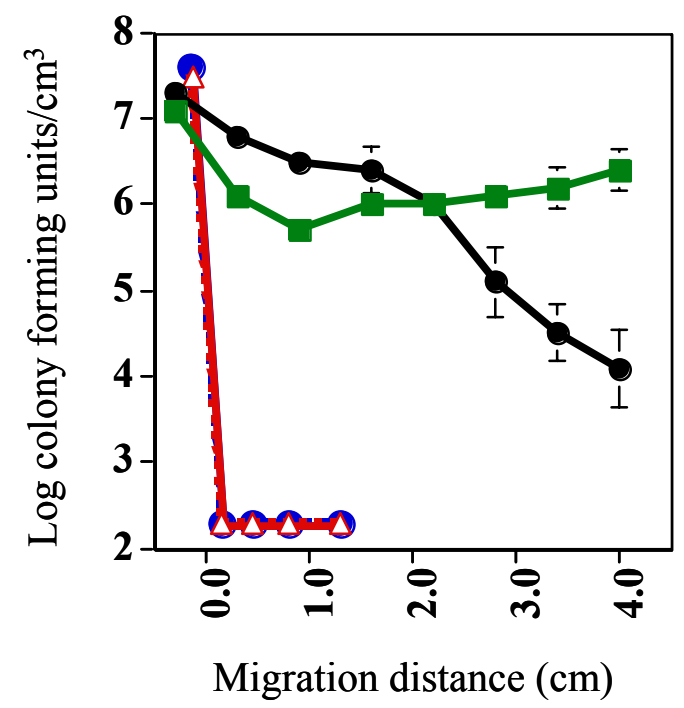

Figure 1. Effect of Volumetric Water Content on Motility-Driven Migration of Ps. Stutzeri KC in Static Unsaturated Columns. Bacteria were inoculated at -0.6 to $0.0 \mathrm{~cm}$. Three of the four treatments did not contain nutrients to support growth; the treatment designated with triangles contained nutrients.

The ability of microbes to colonize unsaturated porous media in the presence of flow and soluble nutrients was studied in a two-dimensional chamber, $40 \mathrm{~cm}$ wide by $60 \mathrm{~cm}$ high by $1 \mathrm{~cm}$ thick, instrumented to allow periodic visualization of water distribution, nutrient delivery, and microbial activity. Water distribution is visualized by light transmission, nutrient delivery by use of a dye, and microbial activity by periodic addition of salicylate, which causes the genetically engineered bacterium Pseudomonas fluorescens HK44 to produce light in the presence of oxygen. A charge-coupled device camera records data at high resolution $(1 \mathrm{~mm} / \mathrm{pixel})$ and quantifies, in situ, the temporal and spatial interactions between water content, solute transport, and microbial processes. Experiments were conducted with homogenous porous media and with heterogeneous porous media consisting of a wedge of coarse sand within a matrix of finer sand. 
Homogeneous porous media experiments were funded largely by a previous National Science Foundation project, with EMSP funds used for final analyses and numerical modeling. EMSP funds also served to extend the homogeneous systems to heterogeneous layered systems, which are more typical of Hanford sediments.

In a representative homogeneous experiment, microbial colonization spread from a 4-cmdiameter inoculated region to more than $17 \mathrm{~cm}$ in width in 6 days (Figure 2). Colonization advanced upward approximately $3 \mathrm{~cm}$ against a pore water velocity of $60 \mathrm{~cm} / \mathrm{h}$. By Day 3 , the interior region of the colonized zone no longer responded to the application of salicylate, indicating that oxygen was depleted in this region. Microbial growth caused a 5-cm lowering of the capillary fringe in the chamber and a localized zone of desaturation in the vicinity of the most heavily colonized region. The permeability of the most heavily colonized area was reduced enough to alter water flow significantly.

Experiments with heterogeneous porous media employed a wedge of coarse sand to provide a capillary barrier and introduce initial spatially variable flow. Processes similar to those noted in the homogeneous experiments were observed (Figure 3). In addition, microbial growth caused an increase in the water content perched upon the wedge. Although the increase in water content was insufficient for flow to break through the capillary barrier into the fine sand under the conditions of the one-week experiment, we believe longer experiments or a slightly higher applied flux would produce this result.

These experiments demonstrate that microbial growth causes dynamic changes in flow paths and hydraulic properties. They also indicate that physical heterogeneity strongly controls microbial activity and colonization in the unsaturated zone.

Results from these experiments are being used as input to parameterization and testing of a twodimensional finite-difference numerical model for predicting contaminant fate and transport in the vadose zone. This model accounts for water flow, transport of solutes and bacteria, microbial growth and degradation kinetics, gas diffusion, and interphase exchange. The model captures new information on interactions between microbial dynamics and vadose zone processes that can be applied in conjunction with experimental studies to gain insights into, and greater understanding of, these processes and phenomena.

We also have collaborated with the U.S. Geological Survey on its Toxic Substances Hydrology Program in the analysis of samples from the Amargosa Desert Research Site (ADRS) in Beattie, Nevada, to determine if far-field migration of ${ }^{14} \mathrm{C}-\mathrm{CO}_{2}$ may be attributable to microbial activity. Land disposal of low-level mixed organic-radioactive waste occurred at both the ADRS and the Hanford Site, and the ADRS serves as an analog for understanding processes occurring at Hanford. The data showed that microbial populations and activity were very low away from the burial trenches and the capillary fringe and would not be generating measurable ${ }^{14} \mathrm{C}-\mathrm{CO}_{2}$. The results indicate that microorganisms in and immediately adjacent to the buried waste are generating the ${ }^{14} \mathrm{C}-\mathrm{CO}_{2}$ and that physical transport processes controlled by the site geology are causing far-field migration. 

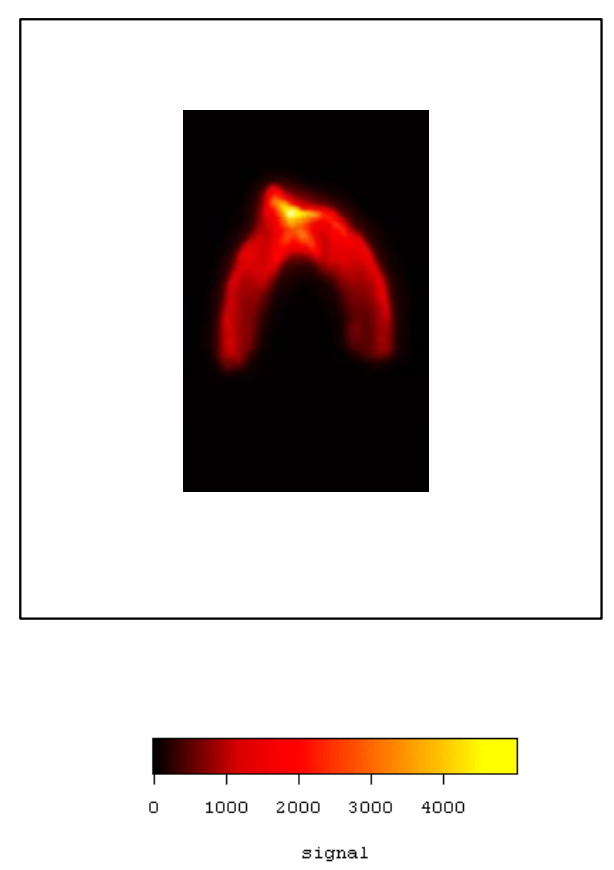

\section{Light signal}
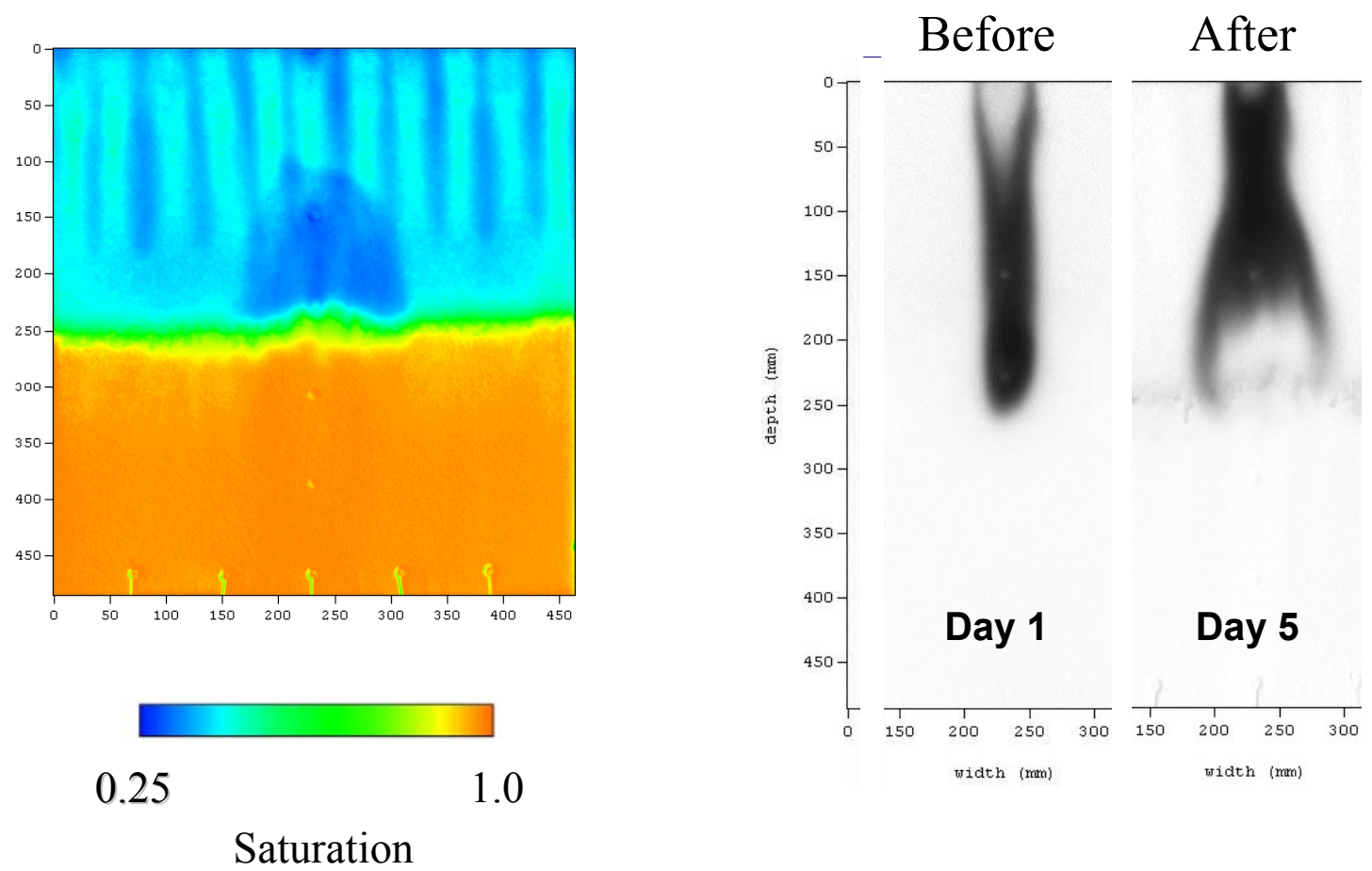

Figure 2. Direct, Noninvasive Observation of Microbial Distribution and Activity (top) with Simultaneous Monitoring of Water Content Distribution (bottom left) and Flow Paths (bottom right) in Unsaturated Porous Media. Microbial growth resulted in diversion of flow (bottom right) 

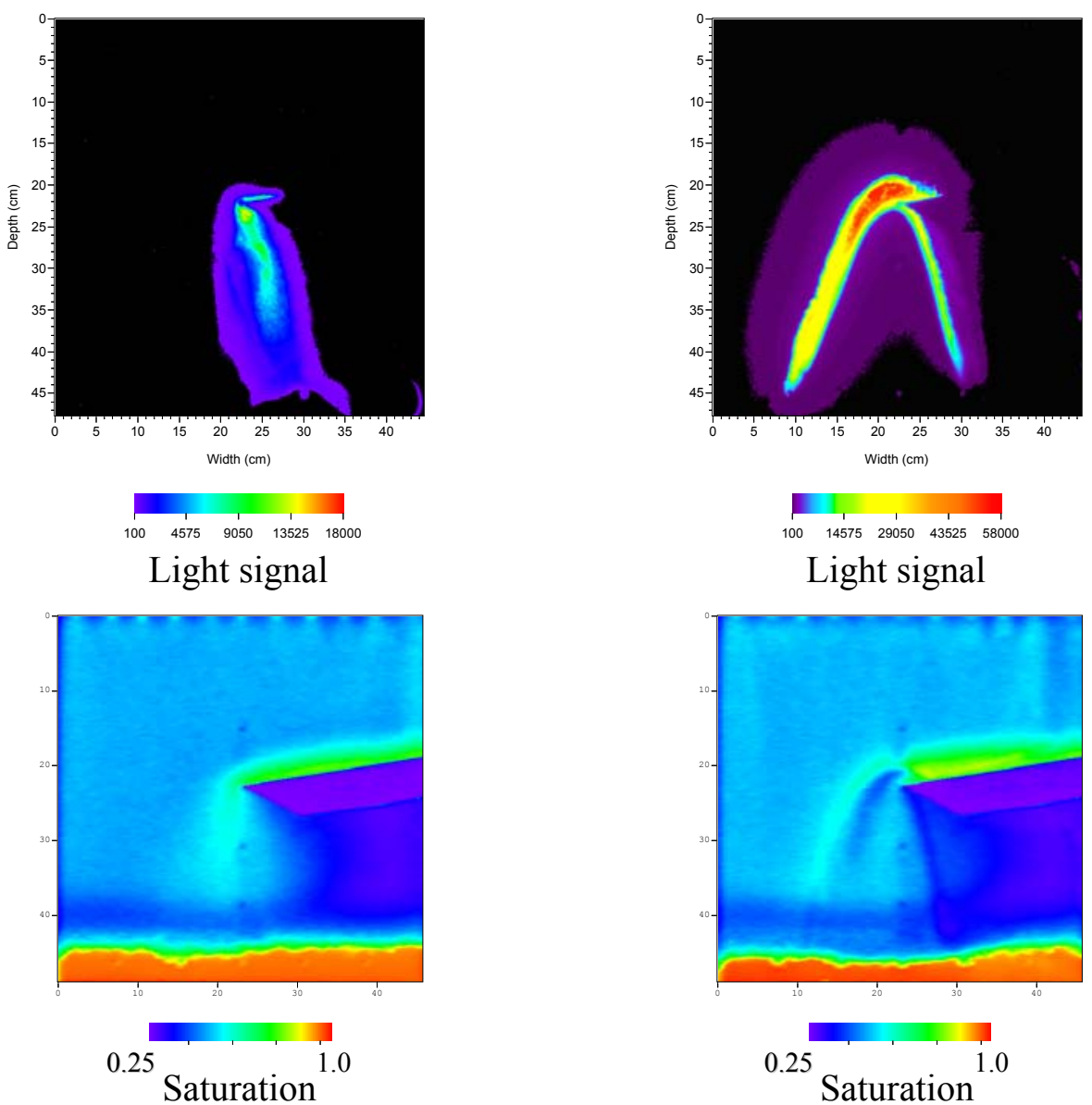

Figure 3. Evolution of Microbial Growth and Activity (top) and Effect of Microbial Growth on Water Distribution (bottom) at Day 2 (left panels) and Day 6 (right panels). Note the scale of the upper right panel is $3 x$ broader than the scale of the upper left panel.

\section{Planned Activities}

Because of the long delay in obtaining samples from the Hanford Site, some project scope definitions have been modified from those of our original proposal:

\section{Samples from the Hanford 216-Z-9 trench site}

- Complete analysis of field samples (remainder of FY 2001).

- Evaluate whether isolates from enrichments are useful for unsaturated chamber experiments using gaseous phase nutrients (remainder of FY 2001). 


\section{Microbial colonization in static unsaturated columns}

- Determine effects of starvation, porous media with smaller particle sizes, and natural porous media with broad particle size distributions on motility and colonization (remainder of project).

- Determine to what extent carbon tetrachloride degradation can be achieved at different microbial cell densities in a bulk aerobic system (i.e., the unsaturated zone).

\section{Unsaturated flow chambers}

- Develop and use bacterial reporters engineered with constitutive and inducible fluorescent proteins for simultaneous real-time characterization of population density and degradation activity (remainder of FY 2001).

- Continue validation of numerical model for predicting contaminant fate and transport in the vadose zone (remainder of project).

- Investigate the spatial and temporal dynamics of microbial processes using gaseous sources of carbon, nitrogen, and phosphorus (remainder of project). 


\section{Distribution}

No. of

\section{Copies}

\section{OFFSITE}

John Ahearne

Sigma Xi

99 Alexander Drive

Research Triangle Park, NC 27709

Mansoor Alam

Department of Materials

New Mexico Tech

Socorro, NM 87801

J. R. Beall

Office of Energy Research

U.S. Department of Energy

19901 Germantown Road (ER-72)

Germantown, MD 20874-1290

Richard Begley

101 Red Oak Lane

Aiken, SC 29803

Jimmy Bell

Bell Consultants, Inc.

137 Bowsprit Lane

Kingston, TN 37763

Edgar Berkey

Concurrent Technologies Corporation

320 William Pitt Way

Pittsburgh, PA 15238

Paul Bertsch

University of Georgia

Savannah River Ecology Laboratory

P.O. Drawer E/Bldg 737 A

Aiken, SC 29801

Robert C. Birtcher

Argonne National Laboratory

Building 212

9700 South Cass Avenue

Argonne, IL 60439
No. of

Copies

David R. Boone

Dept of Env. Sci. and Engineering

Oregon Graduate Institute of Science and Technology

2000 Northwest Walker Road

Beaverton, OR 97006

G. G. Boyd

Office of Environmental Management

U.S. Department of Energy

19901 Germantown Road (5B-014)

Germantown, MD 20874-1290

Michelle Broido

U.S. Department of Energy

19901 Germantown Road, MSIN F-240

Germantown, MD 20874-1290

Barry Burks

Oak Ridge National Laboratory

P.O. Box 2008, Bldg. 7601, MSIN-6304

Oak Ridge, TN 37831-6304

B. Calloway

Westinghouse Savannah River Company

Savannah River Technology Center

Building 773-A/Rm A-229

Mail Stop 28

Aiken, SC 29802

P. M. Castle

Lockheed Martin Idaho Technologies

Company

P.O. Box 1625, MSIN 5205

Idaho Falls, ID 83415

Gregory Choppin

Florida State University

Department of Chemistry (B-164)

$600 \mathrm{~W}$. College Ave.

Tallahassee, FL 32606-3006

Distr.1 
No. of

Copies

Sue B. Clark

Washington State University

Chemistry Department

Pullman, WA 99164

Paul Clayton

Vice President for Academic Affairs

and Provost

Oregon Graduate Institute

P.O. Box 91000

Portland, OR 97291-1000

Larry James

Washington State Univ. at Tri-Cities

100 Sprout Road

Richland, WA 99352-1643

Roger G. Collis

Environmental Technology Partnership

Washington Dept of Community, Trade, and Economic Development

2001 Sixth Avenue, Suite 2700

Seattle, WA 98121

L. Coleman

Washington State Department of Ecology

1315 W. 4th

Kennewick, WA 99336

Julie Conner

U.S. Department of Energy

Idaho Operations Office

785 DOE Place

Idaho Falls, ID 83402

Allen Croff

Martin Marietta Energy Systems, Inc.

Oak Ridge National Laboratory

P.O. Box 2008

Oak Ridge, TN 37831-6178

Rico Cruz

Nez Perce Indian Nation

P.O. Box 365

Lapwai, ID 83450
No. of

Copies

P. M. Davidson

Office of Energy Research

U.S. Department of Energy

19901 Germantown Road (ER-15)

Germantown, MD 20874-1290

S. L. Domoter

Office of Environmental Management

U.S. Department of Energy

19901 Germantown Road (EH-412)

Germantown, MD 20874-1290

Gary Eller

Los Alamos National Laboratory

MSIN E5-10

Nuclear Material Technology Division

Los Alamos, NM 87544

Tom Engel

University of Washington

Department of Chemistry

Bagley Hall Room 109

Seattle, WA 98195-1700

Dennis Faulk

U.S. Environmental Protection Agency

MAF Plaza

712 Swift, Suite 5 (B5-01)

Richland, WA 99352

Tom French

Westinghouse Savannah River Company

Bldg 773-A, A209

P.O. Box 616

Aiken, SC 29802

David Geiser

U.S. Department of Energy EM-52.1

19901 Germantown Road

1183 Cloverleaf Bldg.

Germantown, MD 20874-1290

Joe Gentilucci

JAG Technical Services, Inc.

127 Savannah Drive

Aiken, SC 29803

Distr.2 
No. of

Copies

Kurt D. Gerdes

Office of Science \& Technology

U.S. Department of Energy (EM-541)

19901 Germantown Road

1186 Cloverleaf Bldg.

Germantown, MD 20874-1290

Mark Gilbertson

U.S. Department of Energy (EM-52)

19901 Germantown Road

5A-031/FORS

Germantown, MD 20874-1290

T. R. Ginn

172 Everson Hall

Department of Civil and Environmental

Engineering

University of California, Davis

Davis, CA 95616-5294

Dib Goswami

Washington State Department of Ecology

1315 W. 4th

Kennewick, WA 99336

D. J. Grimes

Office of Energy Research

U.S. Department of Energy

19901 Germantown Road

Germantown, MD 20874-1290

Paul Hart

Morgantown Energy Technology Center

3610 Collins Ferry Road

Morgantown, WV 26507-0880

Thomas Hirons

Los Alamos National Laboratory

P.O. Box 1663, MSIN J591

Los Alamos, NM 87545
No. of

Copies

Roland Hirsch

U.S. Department of Energy

Medical Applications and

Biophysical Research Division

19001 Germantown Road (ER-73)

Germantown, MD 20874-1290

Earl Holtzscheiter

Westinghouse Savannah River Company

Building 773-A/Rm A-229

Mail Stop 28

Aiken, SC 29802

Ken Hubbard

Asst Asso. Provost for Research

and Economic Development

Dean of Graduate School

University of Montana

University Hall 118

Missoula, MT 59812-1329

Tom Isaacs

Lawrence Livermore National Laboratory

P.O. Box 808, MS/L-19

Livermore, CA 94551

Art Janata

School of Chemistry and Biochemistry

Georgia Institute of Technology

Atlanta, GA 30332-0400

Arvid Jensen

Lockheed Martin Idaho Technologies

Company

P.O. Box 1625

Idaho Falls, ID 83415-3204

James R. Karr

Dept. Fisheries and Zoology

104 Fisheries Center

University of Washington

Seattle, WA 98195 
No. of

Copies

Ken Kemner

Argonne National Laboratory

ER203 C-129

9700 S. Cass Ave.

Argonne, IL 60439

Roy Koch

Vice Provost for Research

Dean of Graduate Studies

Portland State University

P.O. Box 751

Portland, OR 97207-0751

Bruce Kowalski

Chemistry Department (BG-10)

University of Washington

Seattle, WA 98195

Alvin Kwiram

Vice Provost for Research

University of Washington

312 Gerberding Hall

P.O. Box 351237

Seattle, WA 98195-1237

Brenda Lewis

Westinghouse Savannah River Company

P.O. Box 616

Aiken, SC 29802

Paul Lurk

U.S. Department of Energy (EM-542)

19901 Germantown Road

1168/Cloverleaf Bldg.

Germantown, MD 20874-1290

R. S. Marianelli

Office of Energy Research

U.S. Department of Energy

19901 Germantown Road (ER-14)

Germantown, MD 20874-1290

M. R. Martin

Lockheed Martin Idaho Technologies

Company

P.O. Box 1625, MSIN 2424

Idaho Falls, ID 83415
No. of

Copies

Todd Martin

Hanford Advisory Board

West 1408 Broadway

Spokane, WA 99201

R. N. Massey

Office of Environmental Management

U.S. Department of Energy

19901 Germantown Road (EM-64)

Germantown, MD 20874-1290

C. Phil McGinnis

Martin Marietta Energy Systems, Inc.

Oak Ridge National Laboratory

P.O. Box 2008

Oak Ridge, TN 37821-6273

M. E. McIlwain

Lockheed Martin Idaho Technologies

Company

P.O. Box 1625, MSIN 2210

Idaho Falls, ID 83415

D. Meisel

Radiation Laboratory

University of Notre Dame

Notre Dame, IN 46556

W. D. St. Michel

Lockheed Martin Idaho Technologies Company

P.O. Box 1625, MSIN 1061

Idaho Falls, ID 83415

D. L. Miller

Lockheed Martin Idaho Technologies Company

P.O. Box 1625, MSIN 2208

Idaho Falls, ID 83415

W. S. Millman

Office of Energy Research

U.S. Department of Energy

19901 Germantown Road (ER-14)

Germantown, MD 20874-1290

Distr.4 
No. of

Copies

Jerry Morin

Westinghouse Savannah River Company

Savannah River Technology Center

P.O. Box 616

Aiken, SC 29802

Alexandra Navrotsky

Department of Chemical Engineering

and Material Science

University of California-Davis

Davis, CA 95616

Tina Nenoff

Sandia National Laboratories

P.O. Box 5800

Albuquerque, NM 87185-0709

J. M. Owendoff

Office of Environmental Management

U.S. Department of Energy

19901 Germantown Road (5A-014)

Germantown, MD 20874-1290

Ken Osborne

DOE Idaho Operations Office

785 DOE Drive

Idaho Falls, ID 83401

Robert T. Paine

Department of Chemistry

University of New Mexico

Albuquerque, NM 87131

Frank Parker

Vanderbilt University

400 24th Avenue South

New Engineering Building, Room 108C

Nashville, TN 37235

A. A. Patrinos

Office of Energy Research

U.S. Department of Energy

19901 Germantown Road (ER-70)

Germantown, MD 20874-1290
No. of

$\underline{\text { Copies }}$

Michael R. Pfister

U.S. Department of Energy, EM-1

Environmental Management Advisory

Board

1000 Independence Ave., SW, Rm. 5B-171

Washington, DC 20585

Ken Picha

U.S. Department of Energy (EM-32)

Office of Eastern Operations

19901 Germantown Road 343/TREV

Germantown, MD 20874-1290

Linfeng Rao

Lawrence Berkeley National Laboratory

MS 70A-1150

1 Cyclotron Road

Berkeley, CA 94720

Kenneth N. Raymond

Department of Chemistry

University of California at Berkeley

Berkeley, CA 94720

Doug Riggs

Legislative Director

Office of Congressman Doc Hastings,

4th District, Washington

1323 Longworth Building

Washington, DC 20515

Gary D. Roberson

DOE Albuquerque Operations Office

Pennsylvania and $\mathrm{H} \mathrm{St}$

Kirtland Air Force Base

Albuquerque, NM 87116

Dave Robertson

DOE Idaho Operations Office

785 DOE Drive

Idaho Falls, ID 83401 
No. of

Copies

D. Max Roundhill

Department of Chemistry

Texas Tech University

Lubbock, TX 79409-1061

Richard Scanlan

Dean of Research

Oregon State University

Administration Services Bldg A312

Corvallis, OR 97331

Wally Schulz

5314 Arbustos Court, NE

Albuquerque, NM 87111

William L. Scott

DOE Idaho Operations Office

785 DOE Drive

Idaho Falls, ID 83401

John S. Selker

Oregon State University

Corvallis, OR 97331

D. R. Sherwood

U.S. Environmental Protection Agency

MAF Plaza

712 Swift, Suite 5 (B5-01)

Richland, WA 99352

Jean'ne Shreeve

Vice President for Research and

Graduate Studies

Professor of Chemistry

University of Idaho

Moscow, ID 83843-4199

Leon T. Silver

Div. of Geological and Planetary Sciences

California Institute of Technology, 170-25

1200 East California Street

Pasadena, CA 91125
No. of

Copies

Robert Smith

Vice Provost for Research

Dean of Graduate School

Washington State University

Pullman, WA 99164-1030

R. N. Snelling

Lockheed Martin Idaho Tech Co

P.O. Box 1625, MSIN 2213

Idaho Falls, ID 83415

Joseph D. Spencer

SCUREF

Strom Thurmond Institute

Clemson, SC 29634-5701

Peter Spencer

Center for Research on Occupational and Environmental Toxicology L606

Oregon Health Sciences University

3181 SW Sam Jackson Park Road

Portland, OR 97202-3098

Ellen Stallings

Los Alamos National Laboratory

SM \#30 Bikini Road

Los Alamos, NM 87545

Alex Stone

Washington State Department of Ecology

1315 W. 4th

Kennewick, WA 99336

Harold Sullivan

Los Alamos National Laboratory

P.O. Box 1663

Los Alamos, NM 87545

John Swanson

1318 Cottonwood

Richland, WA 99352

Robert Swenson

Vice President for Research

Montana State University

Montana Hall 207

Bozeman, MT 59717

Distr.6 
No. of

Copies

Larry Tavlarides

Syracuse University

334 Hinds Hall

Syracuse, NY 13244

Tom Thomas

Lockheed Martin Idaho Technologies

Company

P.O. Box 1625, MSIN 3458

Idaho Falls, ID 83415-3423

Major Thompson Steadman Upham

Vice Provost/Dean of Graduate School

University of Oregon

112 Johnson Hall

Eugene, OR 97403-1226

Scott W. Tyler

Desert Research Institute

7010 Dandini Blvd.

Reno, NV 89512

Nancy Uziemblo

Washington State Department of Ecology

1315 W. 4th

Kennewick, WA 99336

George Vandegrift

Argonne National Laboratory

Building 205

9700 South Cass Avenue

Argonne, IL 60439

John Veldman

Westinghouse Savannah River Company

Bldg 773-A, A-210

P.O. Box 616

Aiken, SC 29802

Jack Watson

Oak Ridge National Laboratory

P.O. Box 2008

Bldg 4500N, MS-6178

Oak Ridge, TN 37831-6178
No. of

Copies

Tom Weber

6622 West Victoria

Kennewick, WA 99336

Thomas Williams

DOE Idaho Operations Office

785 DOE Drive

Idaho Falls, ID 83401

Tom Winston

Ohio Environmental Protection Agency

401 East 5th Street

Dayton, $\mathrm{OH} 45402$

Jim Wright

U.S. Department of Energy

Savannah River Operations Office

P.O. Box A

Aiken, SC 29802

Lin Yarborough

U.S. Department of Energy

Albuquerque Operations Office

P.O. Box 5400

Albuquerque, NM 87185-5400

\section{ONSITE}

\section{Hanford Contractors}

J. N. Appel R2-12

J. G. April L6-06

W. B. Barton R2-11

R. E. Bauer R4-01

R. J. Cash R2-50

S. C. Foelber H0-09

K. A. Gasper L4-07

P. W. Gibbons K9-91

J. O. Honeyman H6-18

M. N. Jaraysii $\quad \mathrm{H} 0-19$

K. J. Koegler H0-23

J. D. White H0-23 
No. of

Copies

17 U.S. Department of Energy Richland Operations Office

B. Bilson

H0-12

J. W. Day

J. K. Erickson

J. E. Frey

M. J. Glasper

J. P. Hanson

R. A. Holten

P. M. Knollmeyer

P. W. Kruger

L. S. Mamiya

B. M. Mauss

T. P. Pietrok

L. L. Piper

R. M. Rosselli

F. R. Serier

D. E. Trader

J. J. Waring

127 Pacific Northwest National Laboratory

J. F. Adams

R. C. Adams

J. F. Bagley

S. A. Bailey

E. G. Baker

W. R. Barchet

W. F. Bonner

D. M. Boyd

P. R. Bredt (15)

F. J. Brockman

J. W. Brothers

T. M. Brouns

S. A. Bryan

J. L. Buelt

D. M. Camaioni

J. A. Campbell

S. D. Colson

L. R. Corrales

J. G. Darab

J. L. Daschbach

J. L. Devary

D. A. Dixon

T. J. Doherty
K8-50

K8-50

K8-50

K8-50

K8-50

A5-16

A5-11

K8-50

K8-50

H6-60

K8-50

A6-37

A7-50

A6-52

K8-50

T5-54
No. of

$\underline{\text { Copies }}$

D. D. Doneen

K8-21

R. M. Ecker

O. B. Egorov

P. D. Ellis

G. J. Exarhos

L. L. Fassbender

A. R. Felmy

M. D. Freshley

J. L. Fuller

P. A. Gauglitz

R. E. Gephart

J. W. Grate

M. S. Greenwood

R. L. Gruel

M. S. Hanson

J. S. Hartman

B. P. Hay

S. W. Heaberlin

H. L. Heinisch

N. J. Hess

L. D. Kannberg

J. M. Kelley

D. E. Knutson

D. W. Koppenaal

W. L. Kuhn

J. P. LaFemina

M. A. Lilga

P. E. Long

G. J. Lumetta

J. A. Mahaffey

W. J. Martin

L. M. Martucci

B. P. McGrail

G. W. McNair

G. L. McVay

B. J. Merrill

P. D. Meyer

C. J. Murray

J. L. Olson

N. J. Olson

T. L. Page (10)

C.H.F. Peden

L. R. Pederson

W. T. Pennell

L. M. Peurrung

L. R. Pond
Sequim L5/312

P7-22

K8-98

K2-44

K6-05

K8-96

H0-21

K8-02

K6-28

K9-76

K8-93

K5-26

K8-60

K9-02

K5-25

K1-83

K8-31

P8-15

P7-50

K5-02

P7-07

P7-25

K8-98

K7-15

K1-40

K2-12

K9-33

P7-22

K9-38

K6-81

K7-10

K6-81

H0-21

K2-50

K8-15

BPO

K6-81

BSRC/S128

K6-04

K9-18

K8-93

K2-50

K9-34

K6-24

K8-23 
No. of

Copies

L. J. Powell

B. A. Pulsipher

M. J. Quadrel

R. K. Quinn

B. F. Saffell, Jr.

J. D. Saffer

R. J. Serne

S. N. Schlahta

P. A. Scott

L. J. Sealock, Jr.

S. C. Slate

K. L. Soldat

S. L. Stein

T. L. Stewart

B. R. Stults

Y. Su

G. Terrones
No. of

Copies

S. Thevuthasan K8-93

J. J. Thomas K7-10

J. W. Virden K2-44

J. F. Wacker P7-07

R. A. Walters K9-15

T. L. Walton K9-46

Y. Wang K8-93

T. J. Weber P7-56

W. J. Weber K8-93

W. C. Weimer K9-09

R. E. Wildung P7-50

R. E. Williford K2-44

J. M. Zachara K8-96

T. S. Zemanian P7-07

TFA Library (2) K9-69

Hanford Technical Library (2) P8-55 